\title{
Planktonic centric diatoms from the Eastern Alps: morphology, biogeography and ecology
}

\author{
Eugen Rott* \& Werner Kofler
}

\section{Article info}

Received: 23 Jun. 2019

Revision received: 13 Dec. 2019

Accepted: 10 Apr. 2020

Published: 1 Mar. 2021

\section{Associate Editor}

Agata Wojtal

\begin{abstract}
Centric diatoms from 26 lakes along the northern perialpine areas and lower altitude valleys and terraces along the W-E extension of the Eastern Alps (mostly in Austria) were studied with the intention to facilitate taxonomic identification and ecological studies in the context of water quality monitoring according to the Water Framework Directive of the European Community. Eight genera were found: Aulacoseira, Conticribra, Cyclostephanos, Cyclotella, Lindavia, Pantocsekiella, Stephanodiscus, Urosolenia. For more than 30 infrageneric taxa, morphology (light microscopy LM), ultrastructure of frustules (scanning electron microscopy SEM), distribution pattern and ecology were studied. Although most of the morphological and ultrastructural features correspond to earlier findings, some additional observations were recorded and some taxonomic views were critically assessed and commented based on our observations. The most important nomenclature-related updates in recent studies are adapted based on molecular findings in literature (mainly for the genera Lindavia and Pantocsekiella). The most widely distributed taxa found were small single celled centrics (mainly species of the genera Cyclotella s.str., Lindavia, Pantocsekiella and Stephanodiscus) dominating frequently in small enriched lakes. In contrast a few larger oligotraphentic single celled (e.g., Lindavia intermedia) and chain-forming taxa (e.g., Aulacoseira islandica) were found to be restricted to the large lakes. The evaluation of the taxa pattern by Canonical Correspondence Analysis (CCA) identified trophic status and lake size as the two primary influential environmental variables for taxa distribution within the dataset. The trophic ranking of species is set in relation to earlier studies and indicator lists.
\end{abstract}

Key words: Coscinodiscophyceae, ecological water quality, ultrastructure, Water Framework Directive, Aulacoseiraceae, Stephanodiscaceae

\section{Introduction}

Centric diatoms are common elements of phytoplankton in many types of lakes, ponds and artificial water bodies (reservoirs) in the Eastern Alps from the lowlands to the highest mountains. This contribution focuses on lower altitude areas close to human settlements where seasonal development of centric diatoms shows a preference for the mixing periods in spring and autumn (cell aggregates, chain-forming taxa and large unicells) and minor peaks during stagnation periods in summer (small unicells) (Reynolds 1984; Rott 1984; Pipp \& Rott 1995). These lowland environments differ in both taxonomic composition (Koinig et al., our own unpublished observations mentioned below) and temporal distributions to high altitude mountain lakes (e.g., in the Pyrenees, Catalan et al. 2013; Rivéra-Rondon \& Catalan 2017). Growing periods

Leopold Franzen's University of Innsbruck, Faculty of Biology, Department Botany, Sternwartestrasse 15, 6020 Innsbruck, Austria

* Corresponding author e-mail: eugen.rott@uibk.ac.at of centric diatoms in lowland and lower mountain regions are regulated, beside seasonal variations of physical turbulence and mixing (influencing shape related sinking rates), by water chemical features, mainly nutrient availability (trophic lake status, characterized by major ions concentrations with special emphasis on carbon and silica, Reynold 1984). Diatoms are indicator taxa for eutrophication, and thus play an important role due to species-specific niche preferences (Dixit et al. 1992; Hall \& Smol 1999; Catalan et al. 2013). Diatoms have been successfully used for environmental quality monitoring of lakes in many eutrophication studies in Europe (Pasztaleniec et al. 2016) and reconstructions of the past eutrophication history from lake sediments, especially in Europe (Catalan et al. 2002, 2013; Rivera-Rondon \& Catalan 2019), but also in other continents, mainly North America (Dixit et al. 1992). In Central Europe (the Alpine Gigue), phytoplankton studies using centric diatoms within indicator methods related to the Water Framework Directive (WFD) European Union 
(2000) were developed mainly for Germany (Mischke et al. 2008), Italy (Buzzi et al. 2011) and Austria (Wolfram et al. 2013, 2014, 2015). Centric diatom studies in Switzerland (Lotter 2001; Hürlimann pers. comm.) focused on the exact reconstruction of lake eutrophication histories based on sediment core studies in order to define near-natural reference situations. From a taxonomic point of view, there were several essential studies of centric diatoms from Europe completed within recent years (especially the recent volumes by Houk et al. 2010, 2014, and 2017). In addition, progress in studies of both morphological and ultrastructural features, combined with molecular markers identifying the genetic relationships of taxa, have led to a world-wide redefinition of the Cyclotella-species complex and the establishment of the new genera Lindavia (Nakov et al. 2015) and Pantocsekiella (Ács et al. 2016). This is why the taxonomic affiliations related to centrics from the Eastern Alps (for Austria see Wunsam et al. 1995) require some updating and adjustment.

From the biogeographic point of view, a large number of taxa from Lindavia and Pantocsekiella seem to be holarctic/circumpolar (Rioual et al. 2017) or even cosmopolitan. In contrast, a certain number of taxa specific to restricted bioregions or environmental settings, with small taxa often overlooked, were detected and taxonomic concepts were changed in recent years with more fine tuning of taxonomy (Cvetkovska et al. 2014; Houk et al. 2014; Rioual et al. 2017). In this respect, this study attempts on one hand to contribute to the knowledge of centric biogeography and, on the other hand, to support environmental monitoring studies related to ecological quality monitoring of lake environments as requested by the WFD.

\section{Materials and methods}

This is a phytoplankton study of lakes situated mostly in and near the low altitude areas of the Eastern Alps near human settlements, which allows the comparison of lake data to river data from other bioregions including small water bodies from the Poland uplands (Wojtal \& Kwandrans 2006), rivers in Hungary (Kiss et al. 2012) and a study of centrics from lakes and rivers in the Anatolia of Turkey (Solak et al. 2018). These accounts definitely contrast with records from high altitude, soft water lakes in the Eastern Alps, which show an additional set of centric diatom taxa (Koinig et al. 1998, 1999; Koinig pers. comm.).

Phytoplankton samples (mostly plankton $20 \mu \mathrm{m}$ mesh size net-hauls and surface water samples) were taken from lakes along an altitudinal gradient between the Eastern lowlands, the extreme eastern slopes of the Eastern Alps in Austria $(<300 \mathrm{~m})$, and a few lakes sampled in low and mid altitudes of the Central Eastern Alps (highest altitude $1600 \mathrm{~m}$ ). The majority of lakes (22) were situated at altitudes below $1000 \mathrm{~m}$ of which nine were below $500 \mathrm{~m}$ altitude. Lake areas varied from $<1$ ha to $>100 \mathrm{~km}^{2}$ $\left(12\right.$ were $>5 \mathrm{~km}^{2}$ ) and were situated along a total extension of $500 \mathrm{~km}$ from Voralberg in the $\mathrm{W}$ to Burgenland in the $\mathrm{E}$ with the majority of large lakes concentrated in the center, especially in the alpine forelands of Upper Austria. One sampling site was south of the Central Alps in South Tyrol (Upper Italy). The species findings are supplemented with simultaneously assessed environmental data (conductivity and temperature) and general ecological and water quality criteria from our earlier studies (Rott 1984; Pipp \& Rott 1995) related to a continuous lake survey program adjusted to meet the requirements of the European Water Framework Directive (European Union, 2000) for the large lakes and additional annual surveys of bathing lakes by the regional governments (Oberösterreichische Landesregierung, 2018). The trophic classifications are mainly based on biological and water chemical components (nitrate, total phosphorus, chlorophyll, phytoplankton composition and biovolume, according to OECD standards (Salmaso et al. 2006; Wolfram et al. 2013, 2014, 2015; Dokulil 2017). It is the intention of the authors to allow accurate identifications using LM, so that the relationships between LM and SEM features may be described in detail.

Thirty three taxa from 26 stagnant water bodies were studied in detail (Table S1) with a focus on the north declination of the central and northern calcareous Alps. A large spectrum of lake sizes and depths were sampled so that distribution patterns became evident, although the sampling of single sites was not exhaustive $(42 \%$ sampled once, $58 \%$ more than twice with a maximum of five times). Sediment samples were treated with $\mathrm{H}_{2} \mathrm{O}_{2}$ and carbonate rich samples pre-treated with $\mathrm{HCl}$ (hydrochloric acid). In several cases, dry mounts were also made (especially for Urosolenia). After washing several times, the materials were embedded into Naphrax (for LM) or dried on cleaned cover glass pieces glued to aluminium stubs, coated with gold-palladium using a Balzers sputter coater SCD 040 and studied with a Philipps XL20 SEM.

The taxonomic part refers to the classification system by Round, Crawford and Mann (1990), taxa identifications by Krammer and Lange-Bertalot (1991) supplemented by the recent volumes by Houk et al. (2010, 2014 and 2017). Internet information from Diatoms of North America (www.diatoms.org), reference papers for Lindavia (Nakov et al. 2015) and Pantocsekiella (Ács et al. 2016), and taxa descriptions from specific literature (StachuraSuchoples and Williams 2009 for Contricribra) were also used. Valve and other dimensions (diameter, striae number etc.) were based on LM and SEM images using a calibration scale for every image. These data are compared to the most recent literature, especially the studies by Houk et al. (2010, 2014 and 2017). We used bright field and ICT light microscopy with up to 1000-times magnifications (Nikon BMX50) with a Progress camera for the BW photographs. Scale bars are included on every photograph and described in each figure legend.

The constrained ordination of the diatom samples (presence/absence data) is based on CCA (Canonical correspondence analysis) to classify samples and taxa in relation to site characteristics (lake size, altitude, lake type, trophic status and conductivity). CCA was done in CANOCO 5 (Šmilauer \& Lepš 2014). The trophic gradient was simulated using the numerical transformation 
of the status classes as follows: 1 (oligotrophic), 2 (oligo-mesotrophic), 5 (mesotrophic) and 8 (eutrophic) (see Figs 29 and 30, Table S2). Lake types were operated as nominal variables: L (large and deep perialpine and alpine lakes), G (gravel pit lakes, deep), P (shallow ponds), $\mathrm{D}$ (small deep lakes) and $\mathrm{R}$ (reservoirs, riverine lakes). The significance of the environmental variables for species distributions used in CCA was statistically tested by the performance of Monte Carlo-Permutation tests (1999 permutations, unrestricted).

\section{Results}

Taxonomy

Morphology, ultrastructure, distribution pattern and ecological data for 33 centric diatom taxa were studied including widespread, rare and typical taxa from Eastern Alpine lakes. LM photographs were supplemented by SEM photomicrographs, as well as by ecological remarks based on the actual data, on literature and long-term observations of lakes by the first author. Detailed site data are presented in Table S1. To facilitate species identification in the LM, we added hints to identify genera and species in the text and supplemented a table allowing the comparison of large, medium and small size Cyclotelloids (especially within the newly established genera Lindavia and Pantocsekiella) with some schematic SEM micrographs (Fig. S1). For some heterogenic species complexes, we did not propose definitive taxonomic affiliations, but intended to show the variability observed here.

\section{Aulacoseira granulata var. angustissima (O. Müller)} Simonsen 1979

(Fig. 1A-G)

Description. Frustules elongated cylindrical, normally arranged in long straight chains, diameter (2.8) 3-5 $\mu \mathrm{m}$, valve diameter to mantle length ratio 1:3.7-1:5.6. In separation valves, the rows of coarse areolae on the mantle are arranged parallel to the main axis (Fig. 1A, C, F), whereas on linking valves, the arrangement of areolae is in dextrorse rows (Fig. 1B, D), 16-22 points in $10 \mu \mathrm{m}$. The linking valves are connected by bifurcated spatulate spines (Fig. 1D arrow, all other broken), in (E) closed ring of spines in SEM hardly visible in LM (A, B). Areolae on mantle closed by volae (D). Characteristic long spines
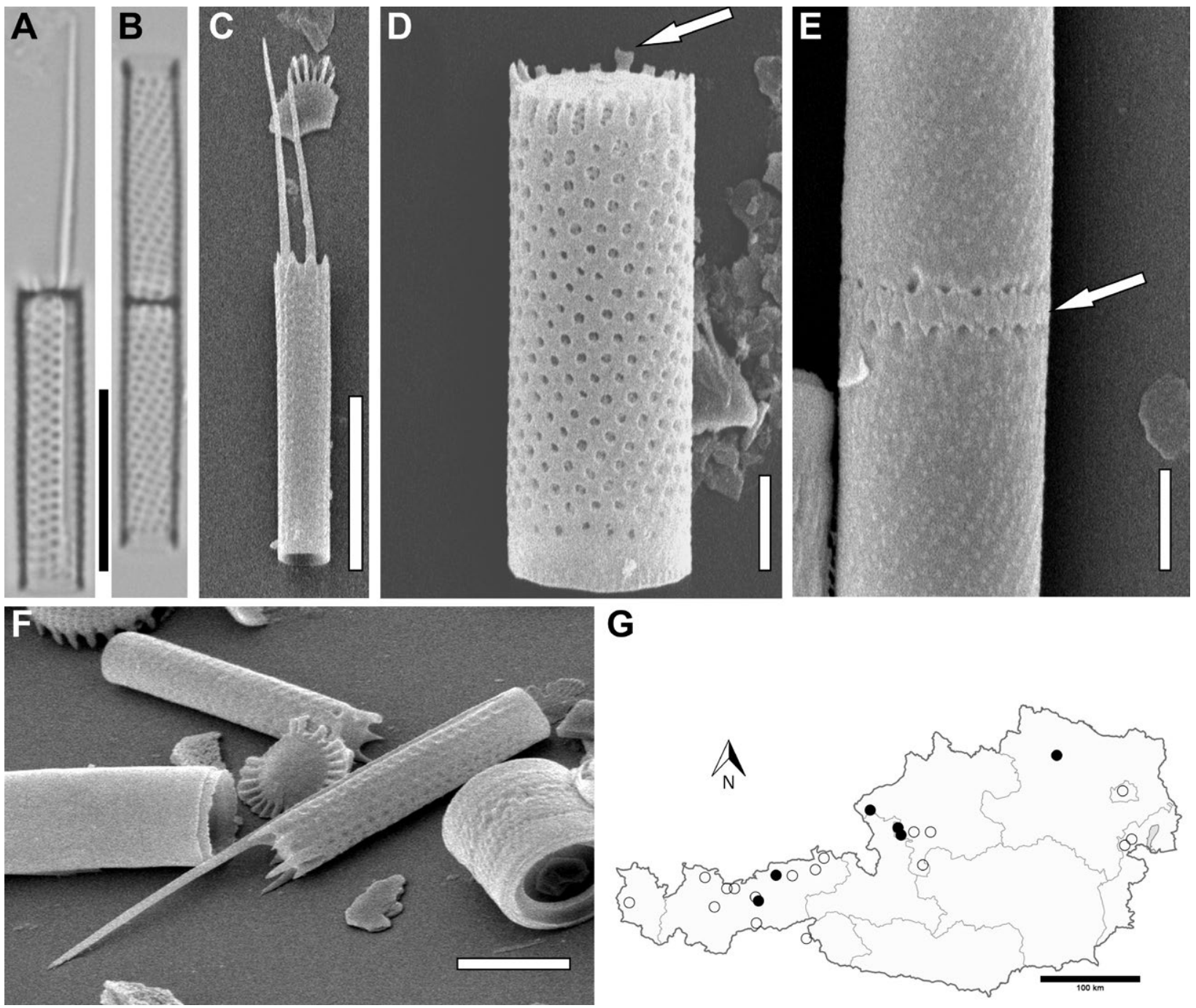

G

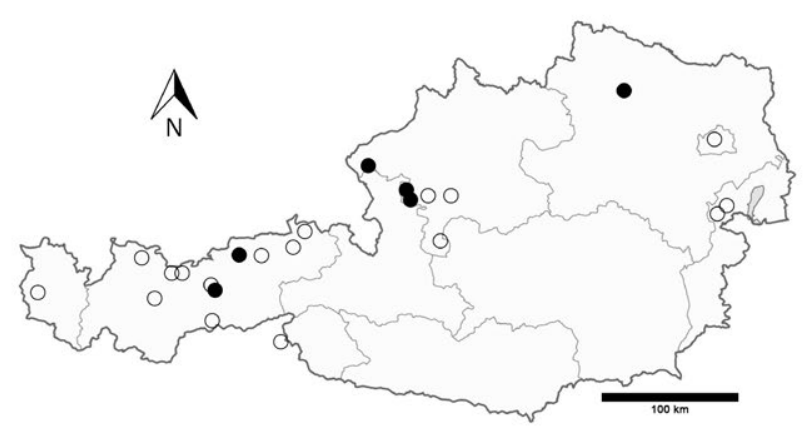

Figure 1. Aulacoseira granulata var. angustissima. A-B - light microscope images (A: separation valve); C-F - scanning electron microscope images (C, F: separation valves; arrow in D: example of bifurcated linking spine, arrow in E: ring of linking spines); $\mathrm{G}-$ sampling locations (black points) along the 26 sampling sites in Austria. Scales: $A-B=10 \mu \mathrm{m}$ (black); $C=10 \mu \mathrm{m}$ (white); D-E = $2 \mu \mathrm{m} ; \mathrm{F}=5 \mu \mathrm{m}$. 
(1-2) on separation valves supplemented by a variable number of smaller spines and grooves for accommodation of spines of the opposite separation valve (Fig. 1C, F). The 'ringleiste' is almost undeveloped, the collar short, the valve flat and ornamented by irregular marginal pores (not shown).

Notes. This is the most common planktonic growth form type of Aulacoseira here, presumably well adapted to planktonic life style (floating). It was not frequent in this dataset (Fig. 1G) due to bias in seasonal sampling. It is unlikely that this form type or species is related within a seasonal life cycle to the larger, shorter and more massive silicified A. muzzanensis (as was put into discussion by H. Kling, Winnipeg, pers.comm.). At this point, we share the view of a separate entity from $A$. granulata by Spaulding and Edlund (2008) and English and Potapova (2010). We assume that A. granulata var. angustissima is a cosmopolitan species, typical for meso- to eutrophic waters. It is more frequent in smaller lakes and ponds underrepresented in this dataset.

\section{Aulacoseira islandica (O. Müller) Simonsen 1979}

(Fig. 2A-H)

Description. Frustules elongated cylindrical, forming long straight chains with a diameter of 5-16 $\mu \mathrm{m}$, mantle height 5-16 $\mu \mathrm{m}$ with a highly variable relationship
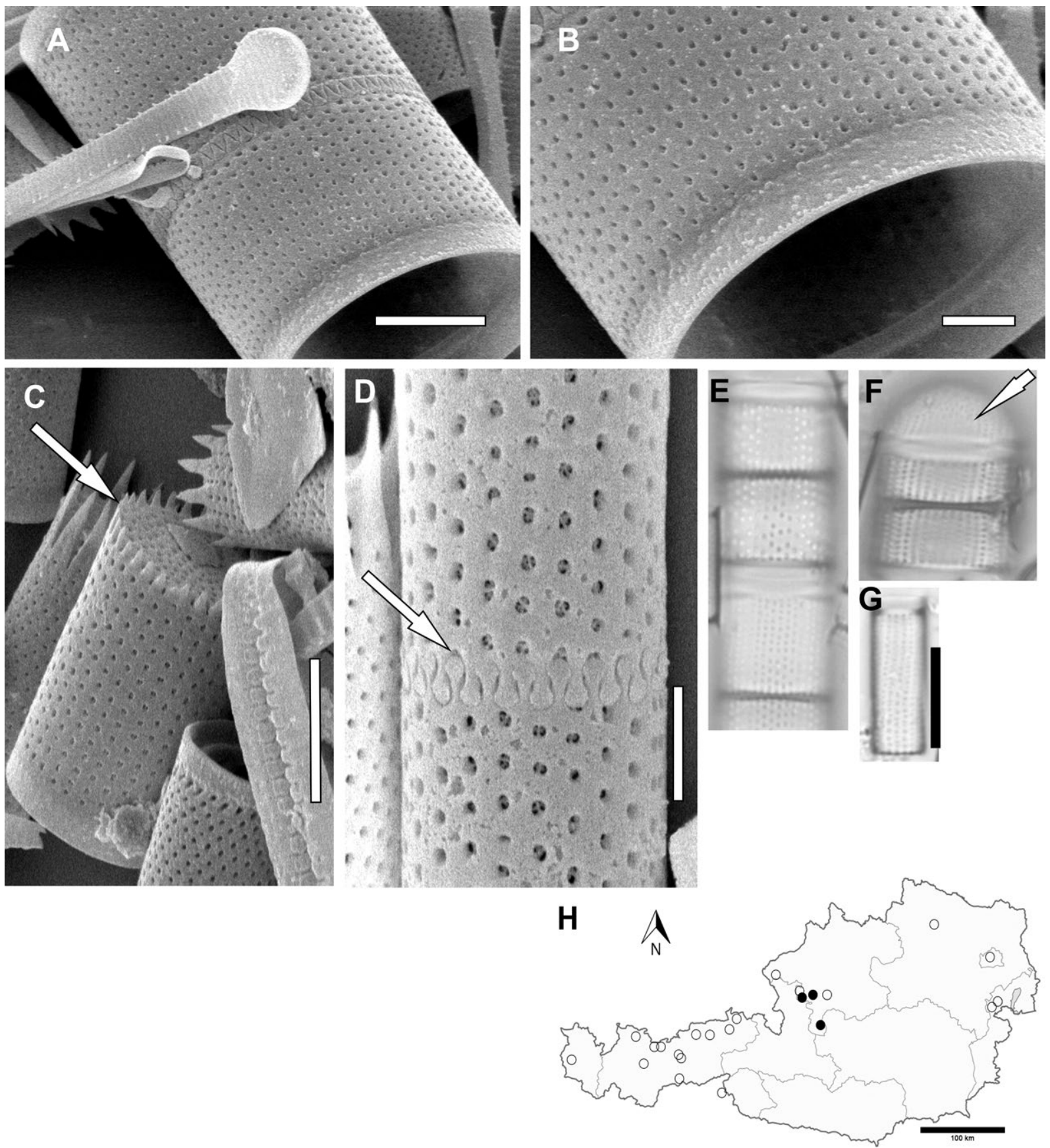

Figure 2. Aulacoseira islandica. A-D - scanning electron microscope images showing linking valves in A-B and D, a separation valve in C (arrow in $\mathrm{C}$ : ring of small separation spines on margin of punctuated valve flat; arrow in D: ring of spatulate linking spines); E-G - light microscope images (arrow in $\mathrm{F}$ : terminal auxospore); $\mathrm{H}-$ sampling locations indicated by black points. Scales: $\mathrm{A}, \mathrm{C}=5 \mu \mathrm{m} ; \mathrm{B}, \mathrm{D}=2 \mu \mathrm{m} ; \mathrm{E}-\mathrm{G}=10 \mu \mathrm{m}$. 

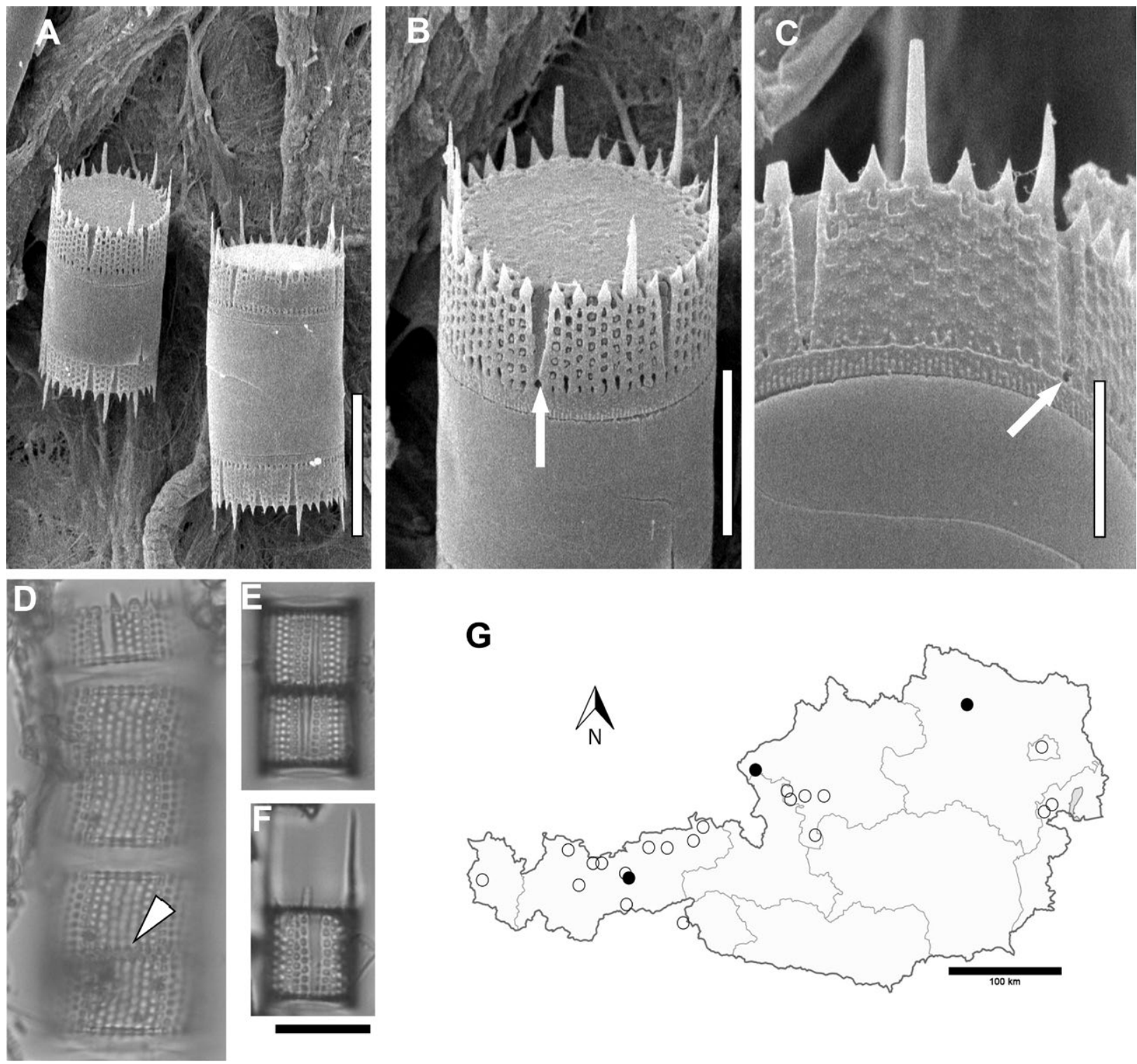

Figure 3. Aulacoseira muzzanensis. A-C - scanning electron microscopic images of double celled short chains with separation valves on both ends (arrows in B-C: position of external opening of labiate process); D-F - light microscope images (D: chain of frustules with separation valve on top (parallel arranged areolae); E: two adjacent separation valves; and F: single terminal separation valve with long spines); $\mathrm{G}$ - sampling locations (black points). Scales: $\mathrm{A}=20 \mu \mathrm{m} ; \mathrm{B}=10 \mu \mathrm{m} ; \mathrm{C}=5 \mu \mathrm{m} ; \mathrm{D}-\mathrm{F}=10 \mu \mathrm{m}$.

of cell length to diameter. Old frustules long and narrow with reduced diameter and with finer punctuation (Fig. 2G). Separation valves show valve face flats with randomly arranged areolae and denser areolae on the mantle (arrow Fig. 2C). Separation valves with regular marginal ring of tiny conical spines hardly visible in the LM. Linking valve with a dense ring of marginal small spatulate / spoonlike spines and mantle with small areolae closed by volae inside (Fig. 2D). Note position of points parallel to the main axis. Ringleiste flat in cross section, $\mathrm{V}$-shaped. Number of rows of areolae $12-18(20)$ in $10 \mu \mathrm{m}$. Auxospores formed frequently as the terminal cells of chains of old (narrow) cells (arrow in Fig. 2F). Freshwater species of oligo- to mesotrophic hardwater lakes, observed here in perialpine lakes up to mid altitudes.

Notes. This taxon has been gradually replaced by Aulacoseira subarctica along a multiannual eutrophication history in Lake Mondsee Austria as observed by detailed studies of sediment cores (Schmidt 1991).

\section{Aulacoseira muzzanensis (Meister) Krammer 1991}

(Fig. 3A-G)

Description. Frustules short cylindrical, often wider than long, cylindrical and forming very short or rarely longer chains, linked by an extended number of shorter and longer acute marginal spines on separation valves (Fig. 3A-C, D, F). The shortest chains consist of two cells, sometimes bearing the extended cell girdle bands (or structureless collars, Houk et al. 2017) on the mantle (Fig. 3A-C). The linking valves have no such long spines, but short spatulate spines (arrowhead Fig. 3D). Diameter is $8-20 \mu \mathrm{m}$, mantle length $10-18 \mu \mathrm{m}$ so that valves can be shorter than wide which is especially frequent in the double cell form (Fig. 3D). In the separation frustules, the rows of areolae (9-12 square shaped points in $10 \mu \mathrm{m})$ 
are arranged linear in parallel to the main axis (E-F) but spirally dextrorse in the linking (connection) valves (D). In the SEM, there is one row of areolae under each spine and another row of areolae between the spines (Fig. 3B). We found mostly square shaped areolae closed by vela. The rimoportulae are situated based on the larger linking spines (arrows in Fig. 3B-C). The valve flat margin is ornamented by an irregular ring of marginal points.

Notes. At this point it is difficult to decide if this taxon is in fact closer to A. granulata (see plate 160 in Houk et al. 2014) or if it is closer to A. muzzanensis sensu (Krammer \& Lange-Bertalot 1991), which in the latter study appears to be much more delicately calcified than the original materials from Lago Muzzano. However, we found this taxon (or morphotype) together with A. granulata var. angustissima suggesting a separation of these two entities (species or ecotypes). Aulacoseira muzzanensis is discussed as a cosmopolitan taxon (Kiss et al. 2012) typical for eutrophic waters. Here, it was found temporarily very frequent in two small artificial eutrophic lakes, but it is underrepresented in the dataset.

\section{Aulacoseira pusilla (F. Meister) Tuji \& Houki 2004}

(Fig. 4A-G)

Description. Frustules are short cylindrical, arranged in short chains of two or four cells only. Cell diameter is (5.5)6-7 $\mu \mathrm{m}$ and the mantle length is (2.5)3-4 $\mu \mathrm{m}$. Mantle areolae arranged in sinistrorse rows (Fig. 4B). The valves are connected by small simple spines, visible in the LM. Each spine is originating above one line of areolae and
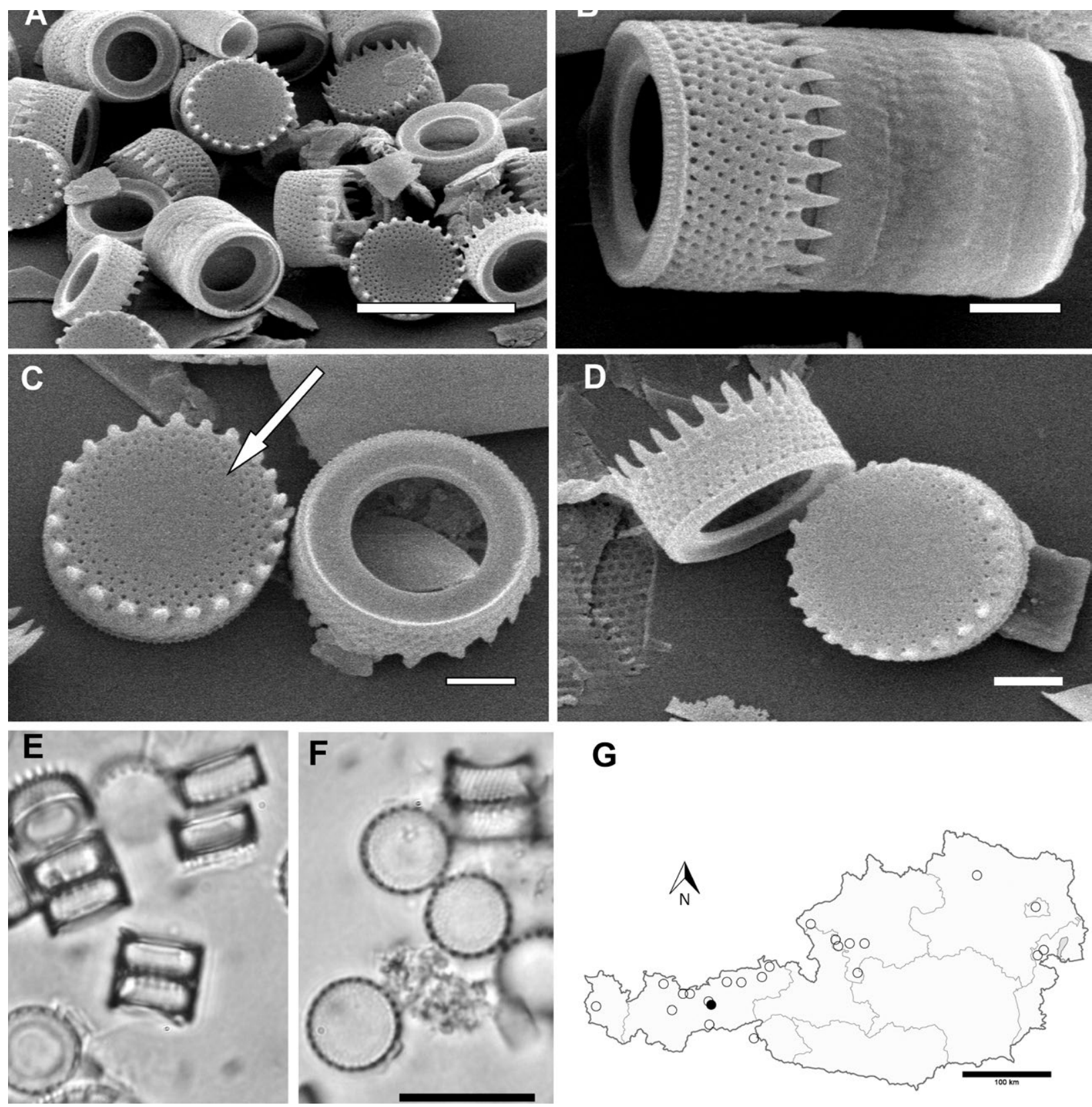

G

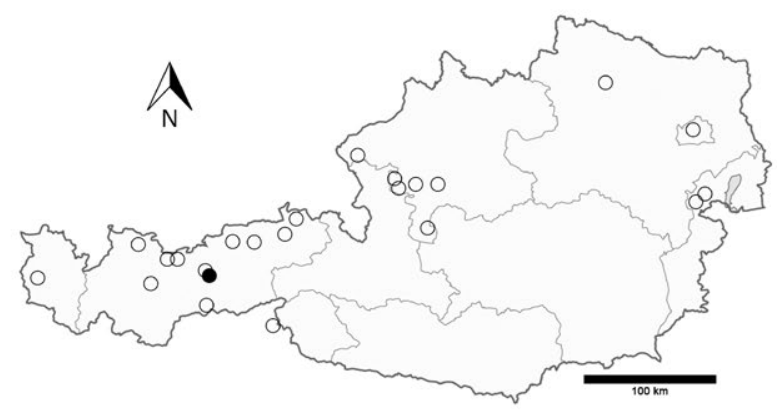

Figure 4. Aulacoseira pusilla. A-D - scanning electron microscope images of various frustule fragments with a majority of linking valves (with minute linking spines); (B: note lateral view with robust ringleiste, linking spines originating from two costae and adjacent mother cell girdle bands; arrow in $\mathrm{C}$ : increasing density of areolae toward valve flat margin); $\mathrm{E}-\mathrm{F}$ - light microscope images; $\mathrm{G}$ - sampling locations (note two very close record black points). Scales: A, E-F $=10 \mu \mathrm{m} ; \mathrm{B}-\mathrm{D}=2 \mu \mathrm{m}$. 
between every spine another line of areolae is situated. Density of mantle points $24-28 / 10 \mu \mathrm{m}$. Areolae on the valve face are irregularly spread and cover variable portions of the diameter (not the whole valve flat, as found for $A$. pusilla from Japan by Houk et al. (2017), sometimes even restricted to the margin. Short collar and regular concentric ringleiste is running considerably into the cell interior. Valve mantle height to diameter ratio 1:0.37-1:0.49. Girdle consisting of several unstructured copulae.

Notes. This taxon differs somewhat from the taxon from Japan (Tuji 2015) by more regular and robust spines on every second line of puncta on the mantle and a higher variability of the areolae on the valve face. It corresponds
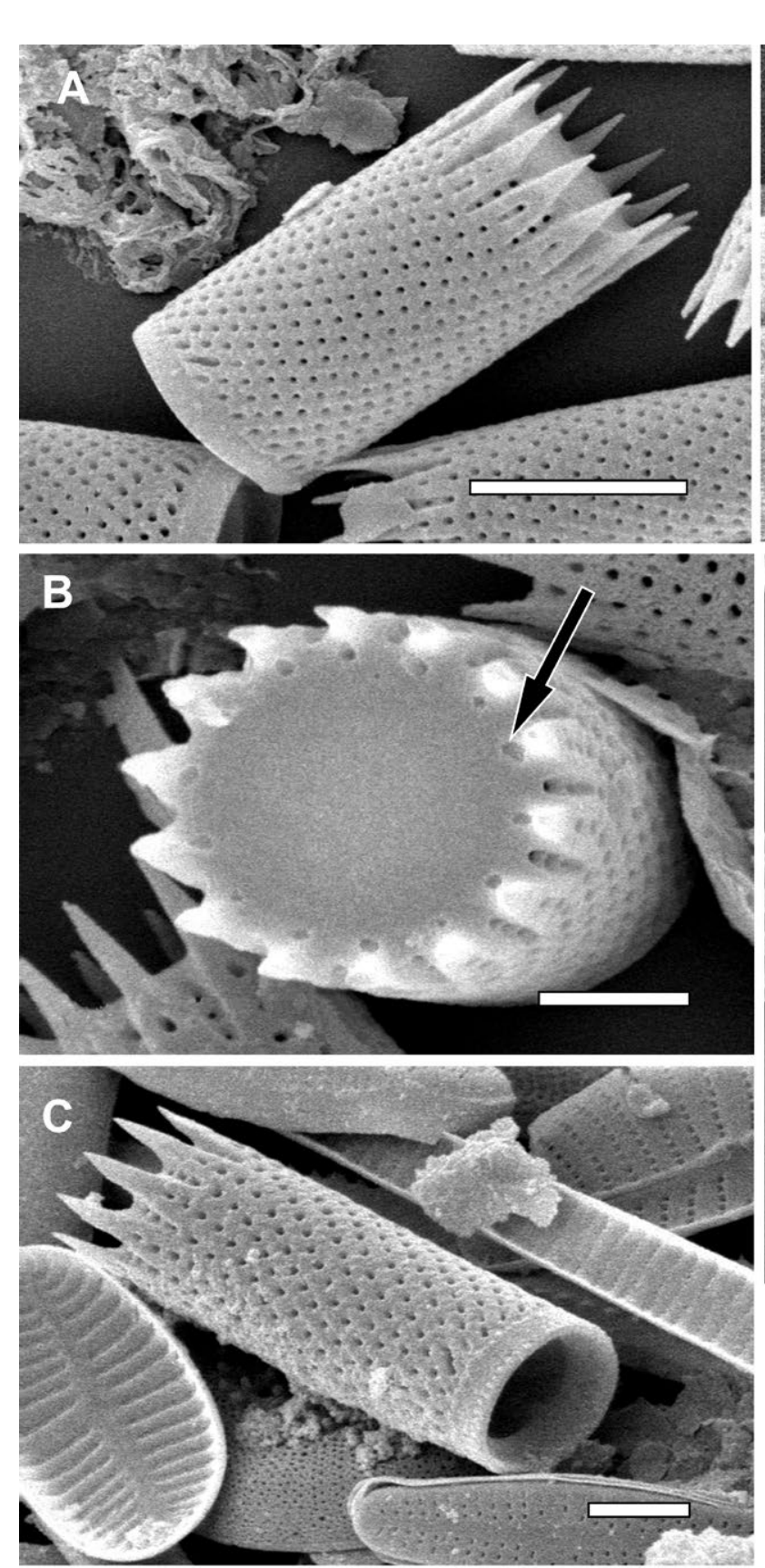

to A. pusilla in Kiss et al. (2012). It also differs from Aulacoseira subborealis (Nygaard) Denys, Muylert and Krammer by more distinct marginal spines and the marginal ring of areolae on the valve flat as shown in Houk et al. (2017). It was forming a temporal bloom in one small eutrophic anthropogenic shallow lake and was also recorded from a small pond nearby.

\section{Aulacoseira subarctica (O. Müller) Haworth 1990}

(Fig. 5A-I)

Description. The frustules are elongated cylindrical forming chains of variable length. Cell size 2.8-6 $\mu \mathrm{m}$ in diameter, mantle length $7.5-16 \mu \mathrm{m}$. There is no
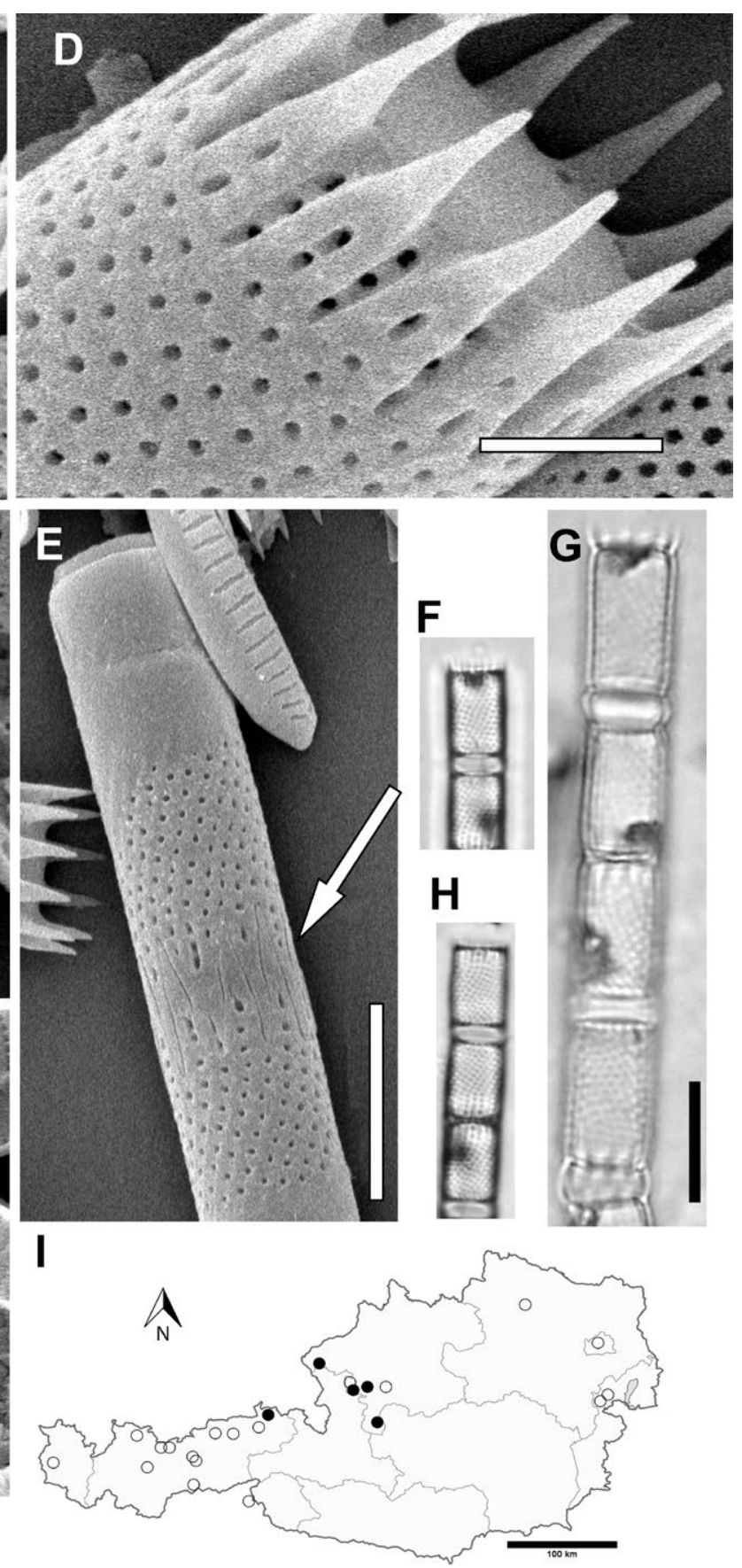

Figure 5. Aulacoseira subarctica. A-E - scanning electron microscope images of separation valves (arrow in B: ring of irregular sized areolae on valve flat margin; arrow in $\mathrm{E}$ : pinpoints to formation of double ring of spines); $\mathrm{F}-\mathrm{H}$ - light microscope images with various valve differentiations. $\mathrm{I}$ - sampling locations (black points). Scales: A, D = 5 $\mu \mathrm{m} ; \mathrm{B}-\mathrm{C}, \mathrm{E}=2 \mu \mathrm{m} ; \mathrm{F}-\mathrm{H}=10 \mu \mathrm{m}$. 
differentiation of spines between linking and separation valves. The marginal ring of the characteristically regular distributed conical and pointed spines are mostly equal in length. In SEM, every second row of areolae is connected to a spine base (i.e., every two costae form a spine, see Fig. 5D). Spines are harboured within the grooves of the opposite separation valve. Those serve also as holdfasts within cell chains (Fig. 5E), but become somewhat divergent in terminal valves (LM Fig. 5G). The mantle is ornamented by dextrose rows of areolae, $15-18-22 / 10 \mu \mathrm{m}$. The face of the valve flat is smooth or sometimes with a somewhat irregular ring of pores/ areolae arranged along the valve margin close to each spine (Fig. 5B, black arrow). The collar is low, ringleiste robust and well developed (Fig. 5C). Frustules disintegrate during cleaning and mounting.

Notes. This taxon is a major component of phytoplankton of Lake Mondsee in Austria in autumn (Schmidt
1991; Dokulil 2017). It was subdominant in other northern perialpine oligo- to mesotrophic lakes in Germany (e.g., Ammersee, Chiemsee) as mentioned by Houk et al. (2014). Records from Hungary only refer to the Danube River (Kiss et al. 2012) and are in fact likely to be drifted specimens from large perialpine lakes upstream in the Danube catchment. Presumably, it is a holarctic phytoplankter of oligo- to mesotrophic environments.

Conticribra weissflogii (Grunow) Stachura-Suchoples \& Williams 2009

(Fig. 6A-G)

Description. Frustules delicate, drum shaped, diameter $12-20 \mu \mathrm{m}$. The pervalvar axis is $<1 / 2$ of diameter. Valve face with a spider-net like grid of irregular polygonal areolae 4-7/1 $\mu \mathrm{m}$ arranged roughly radial (Fig. 6A-B). Marginal fultoportulae 12-14/10 $\mu \mathrm{m}$ external opening with distinct elongated tubes at the valve margin and with three satellite pores seen in the interior of the frustules
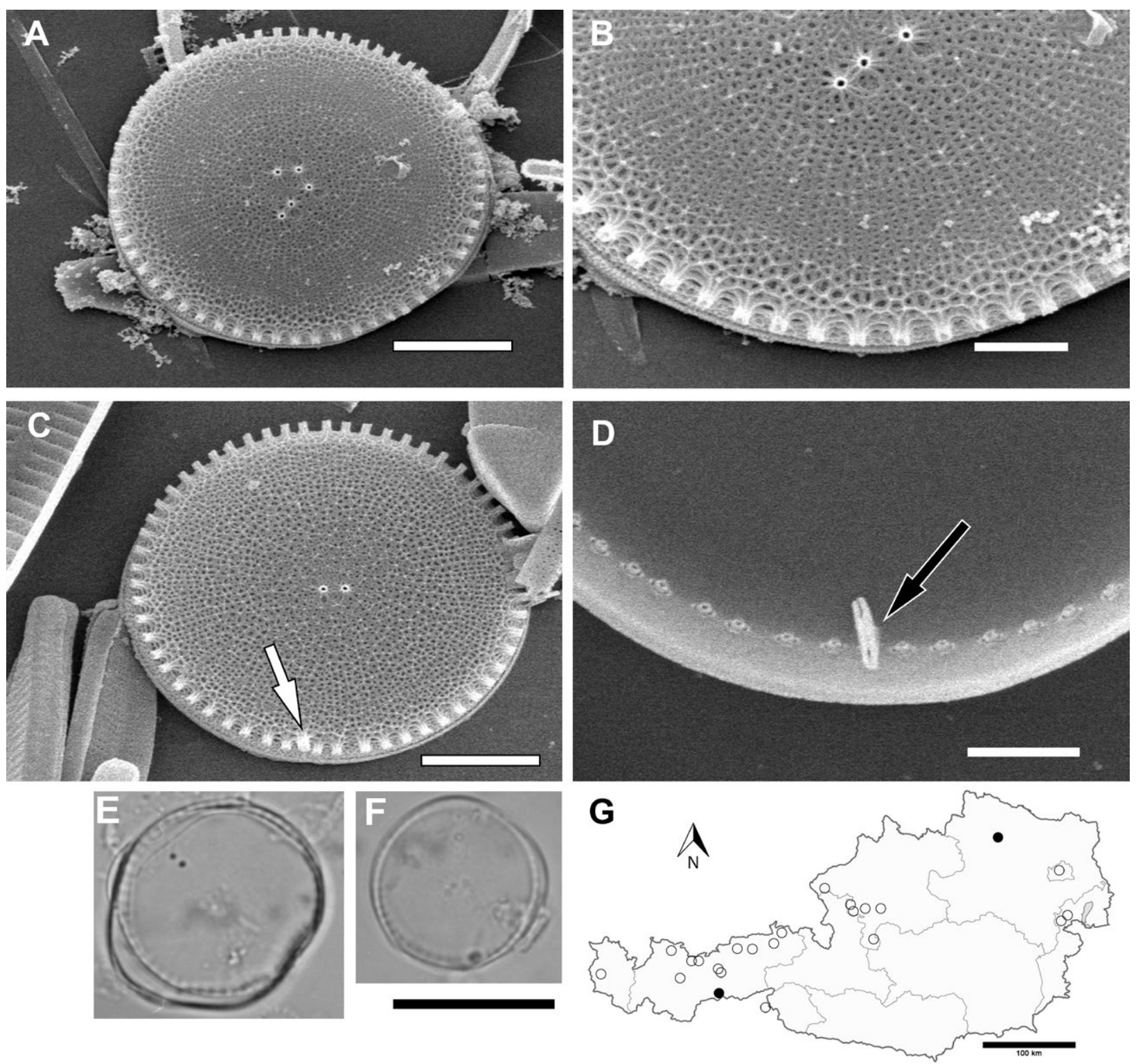

Figure 6. Conticribra weissflogii. A-D - scanning electron microscope images show irregular valve flat pattern with variable number of central fultoportulae (2-5) (arrow in C: one prominent marginal rimoportula; D: interior aspect of rimoportula with broad labiate ending; E-F - light microscope images; $\mathrm{G}$ - sampling record locations (black). Scales: $\mathrm{A}, \mathrm{C}=5 \mu \mathrm{m} ; \mathrm{B}, \mathrm{D}=2 \mu \mathrm{m} ; \mathrm{E}-\mathrm{F}=10 \mu \mathrm{m}$. 
in SEM (Fig. 6D). Within the external marginal ring of fultoportulae one single rimoportula appears with a somewhat larger tubular opening within the marginal ring of fultoportulae (Fig. 6C, white arrow). Its lip in the interior of the frustule is well developed (Fig. 6D, black arrow). A variable number of (2)3-5 valve face fultoportulae were found in the valve center (Fig. 6A, C).

Notes. This Contricribra species is a rare component of phytoplankton in Brennersee, a lake close to the major motorway crossing the Alps at $1300 \mathrm{~m}$, which is charged by highway road salts in winter and therefore classified as meso- to eutrophic. It was also found in a riverine reservoir in NE-Austria. It is not listed in the indicator species lists of Austria (Wolfram et al. 2014). We follow the taxonomy of Kiss et al. (2012) concerning nomenclature of this taxon.

\section{Cyclostephanos dubius (Hustedt) Round 1987}

(Fig. 7A-J)

Description. The robust frustules are short cylindrical and of highly variable size (diameter 4.5-20 $\mu \mathrm{m}$ ), concentrically undulated with convex central part on the epivalve (Fig. 7A-B) and corresponding concave central depression on the hypovalve (Fig. 7C-D). The characteristic
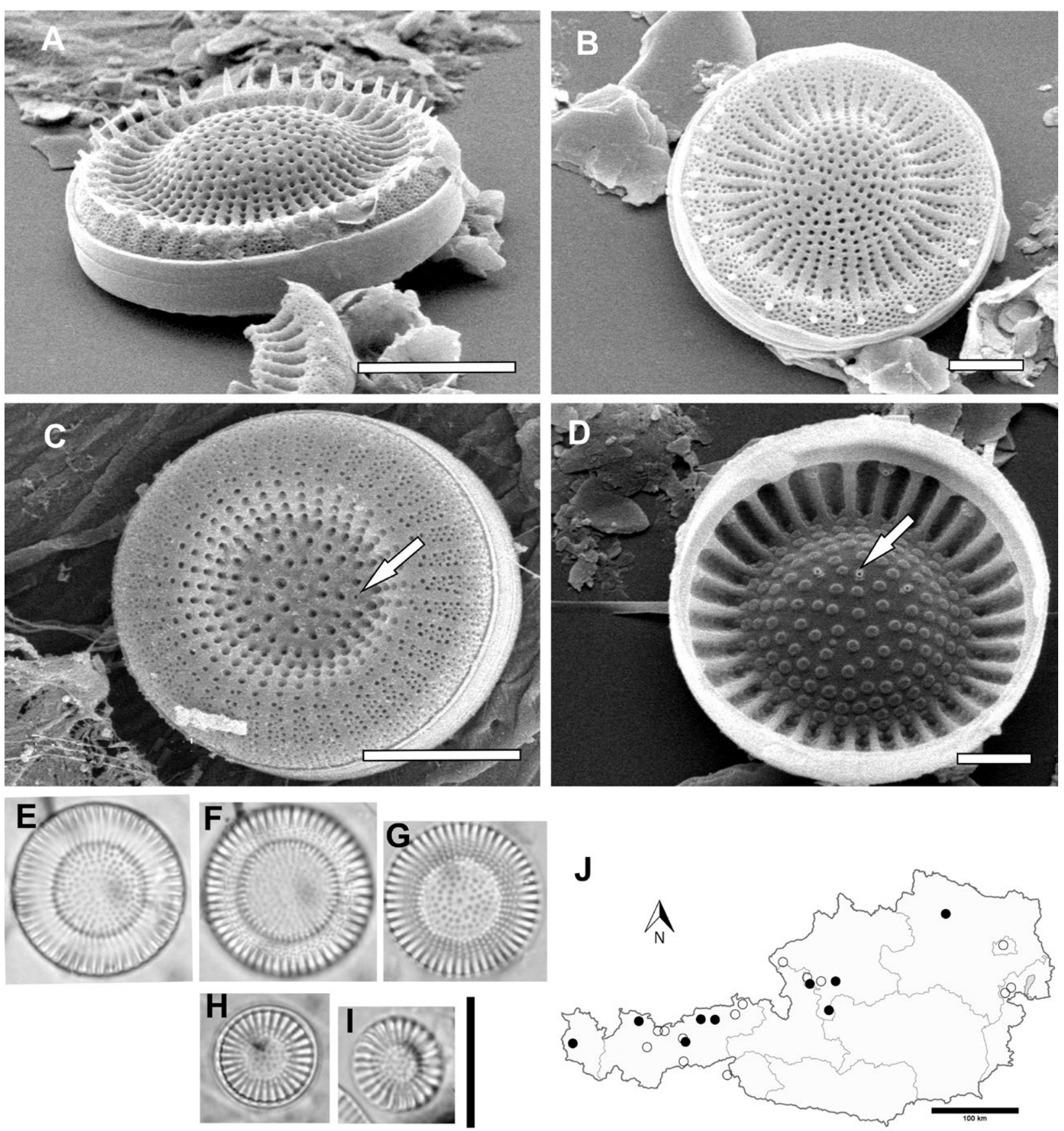

Figure 7. Cyclostephanos dubius. A-D - scanning electron microscope images (A-C: exterior views with variable position of spines (A - on every, B - on every third costa); marginal fultoportulae below spines or in between; C - hypovalve without spines, or spines broken; arrow in C: exterior opening of central fultoportula; D: interior valve view with regular ring of marginal alveolae and marginal fultoportulae on every $3^{\text {rd }}$ costa; arrow in D: shows example of more fultoportulae with 2 satellite pores); E-I - light microscope images show large size variations and variable central inflation; J - sampling record locations (black points). Scales: A, C $=5 \mu \mathrm{m} ; \mathrm{B}, \mathrm{D}=2 \mu \mathrm{m} ; \mathrm{E}-\mathrm{I}=10 \mu \mathrm{m}$. 
costae-like, robust, radial arranged, marginal interfascicles (ribs $12-18 / 10 \mu \mathrm{m}$ ) form more or less distinct alveolar chambers in the marginal area of the frustule and are seen as undulated areas in LM (Fig. 7E-I) with variable extension along the radial axis. Central valve area normally with radial rows of larger and distinct points $25-30 / 10 \mu \mathrm{m}$. Areolae on valve margin in fascicles more delicate, seen in SEM as bundles of puncta in triple rows, extending from valve face into the mantle and gradually reduced to two points toward the middle distance of the radius (arrows Fig. 7C) and reduced to single larger points in the center. The marginal fultoportulae are found irregularly on every $2^{\text {nd }}$ to $4^{\text {th }}$ costa (Fig. 7D), as well as one single rimoportula associated with one costa. The center of the valve has a few (mostly 2-3) fultoportulae with two satellite pores (see arrows in Fig. 7C-D). There is a variable number and irregular arrangement of spines on the valve margin of some morphotypes (Fig. 7B). On other frustules, spines were found on every costa (Fig. 7A).

Notes. This cosmopolitan taxon is found commonly in smaller eutrophic standing waters or in eutrophicated littoral areas of larger lakes where it was also found within the close ground tychoplanktonic communities. It is one of the most common river plankton species in Hungary (Kiss et al. 2012).
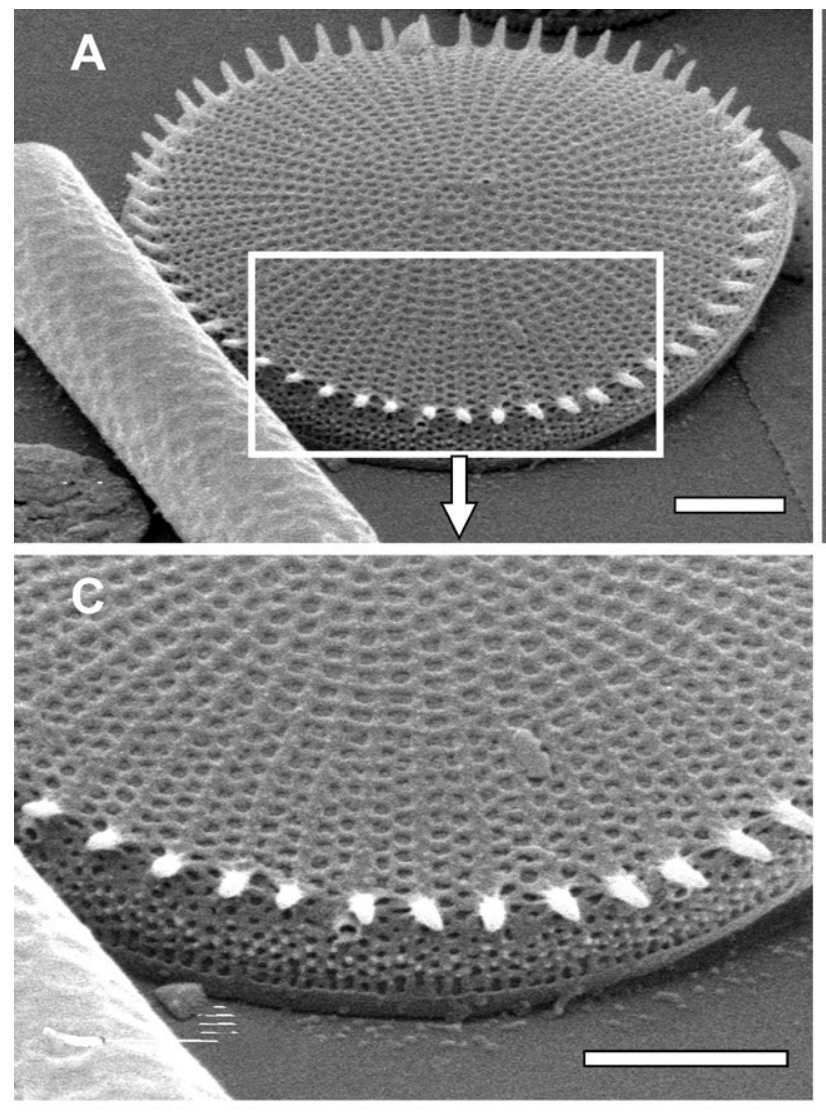

Cyclostephanos invisitatus (Hohn \& Hellermann) Theriot, Stoermer \& Håkkanson 1987

(Fig. 8A-F)

Description. Frustules cylindrical and 5-15 $\mu \mathrm{m}$ in diameter, delicately silicified, so that this taxon tends to be overlooked in the LM. The valve face is flat, ornamented by radially arranged rows of fine poroid areolae closed by vela. One row of points in the center and two rows on the margin, (see Fig. 8A-B) are hardly visible in the LM (Fig. 8D-E). Interstriae more or less regularly ornamented with one marginal spine, number of striae 14-22/10 $\mu \mathrm{m}$ (areolae 20-40). Below each sixth spine is situated one fultoportula with an external single opening, in the interior (Fig. 8C) with short tube and two satellite pores. One rimoportula further out on the mantle of the valve (black arrow Fig. 8B). From the interior view, interstriae are somewhat elevated from the valve flat. Near the center of the valve, one single small fultoportula is found with two satellite pores (white arrow Fig. 8B). The small spines on the valve margin are associated with every interstria. On every $6^{\text {th }}$ interstria one fultoportula is situated.

Notes. Cyclostephanos invisitatus is a widespread taxon of both lakes and rivers. Since it is more common also in eutrophic water bodies, it was rare in this dataset (three sites in Fig. 8F).
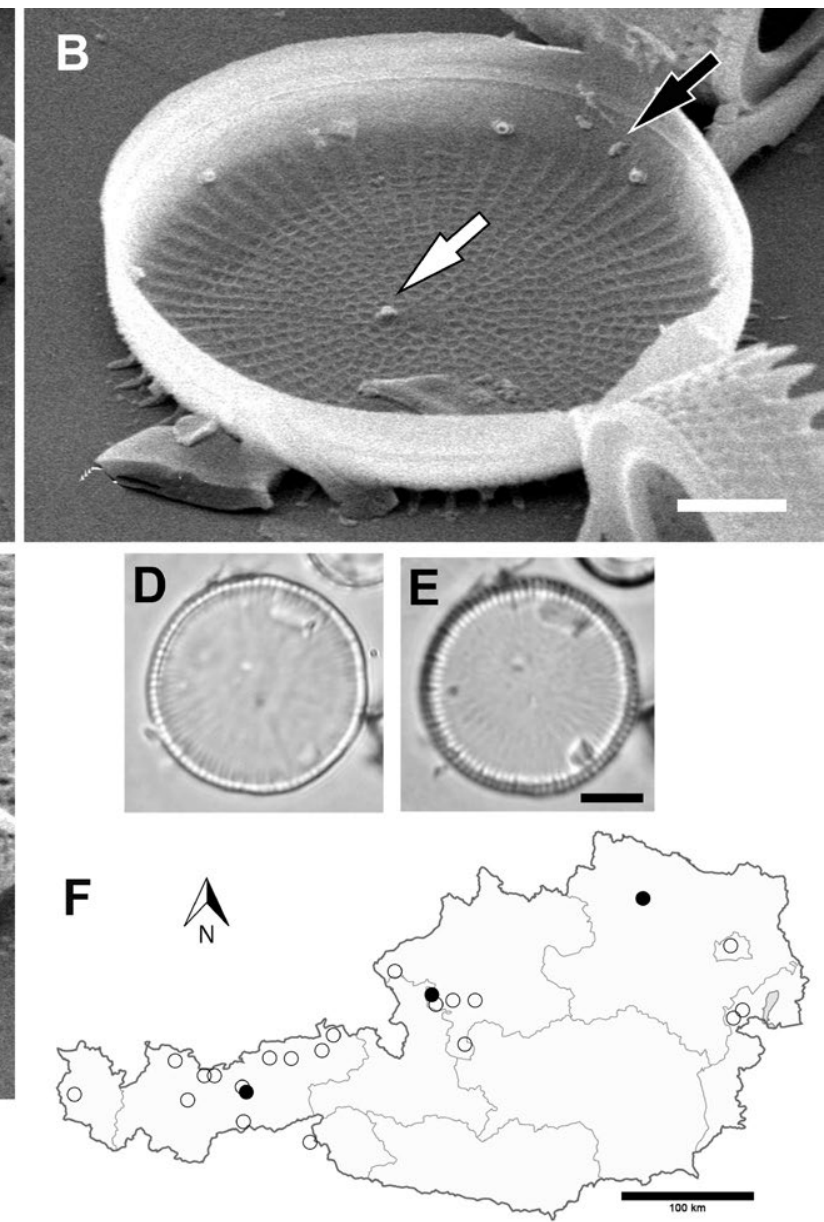

Figure 8. Cyclostephanos invisitatus. A-C - scanning electron microscope images (A, C: exterior view of valve with minute spines on every costa and marginal fultoportulae on every $6^{\text {th }}$ costa; white arrow in B: interior view with one single central fultoportula with two satellite pores, and black arrow in B: one marginal rimoportula); D-E - light microscope images; F - sampling record locations (black). Scales: A-B $=5 \mu \mathrm{m}$; $\mathrm{C}=2 \mu \mathrm{m} ; \mathrm{E}-\mathrm{F}=5 \mu \mathrm{m}$. 


\section{Cyclotella distinguenda Hustedt 1927}

(Fig. 9A-H)

Description. Frustules regular cylindrical, characterized by a larger circular unstructured or somewhat variable scratched, undulated central area (Fig. 9A-B) which is normally concentrically undulated between epi- and hypotheca. These undulations are rarely reduced or totally missing that would relate this taxon to Cyclotella plitvicensis Hustedt, which has no central undulations and has been observed in high mountain lakes in Austria (see Houk et al. 2010). Valves circular with diameter 4-27 $\mu \mathrm{m}$ and a normal frustule height to diameter ratio of 1:2. Auxospore/initial valve sizes vary from 14 to $>20 \mu \mathrm{m}$ in diameter. The valve center is devoid of areolae and processes. The valve margin is ornamented by a very regular number of striae and interstriae (Fig. 9C) clearly visible in the LM (13-18/10 $\mu \mathrm{m})$ and characterized by mostly even central endings (Fig. 9E, G). The striae are longer than the internal alveolae, which are normally elliptic in cross section, rarely circular. In LM, those appear as a less distinct shadow line. Fultoportulae with three satellite pores are situated most frequently on every $4^{\text {th }}$ costa, but sometimes on every $3^{\text {rd }}, 2^{\text {nd }}$ or even neighboring costae. One rimoportula with distinct labiate ending in the inside is alternating to the neighboring fultoportulae (arrow in Fig. 9D). External marginal fultoportulae show simple openings below costae. The interstriae (costae) are separating rows of minute areolae $(42-55 / 10 \mu \mathrm{m})$ that normally start as triple near the margin and are reduced to pairs close to the central area endings (see Håkansson 1989).
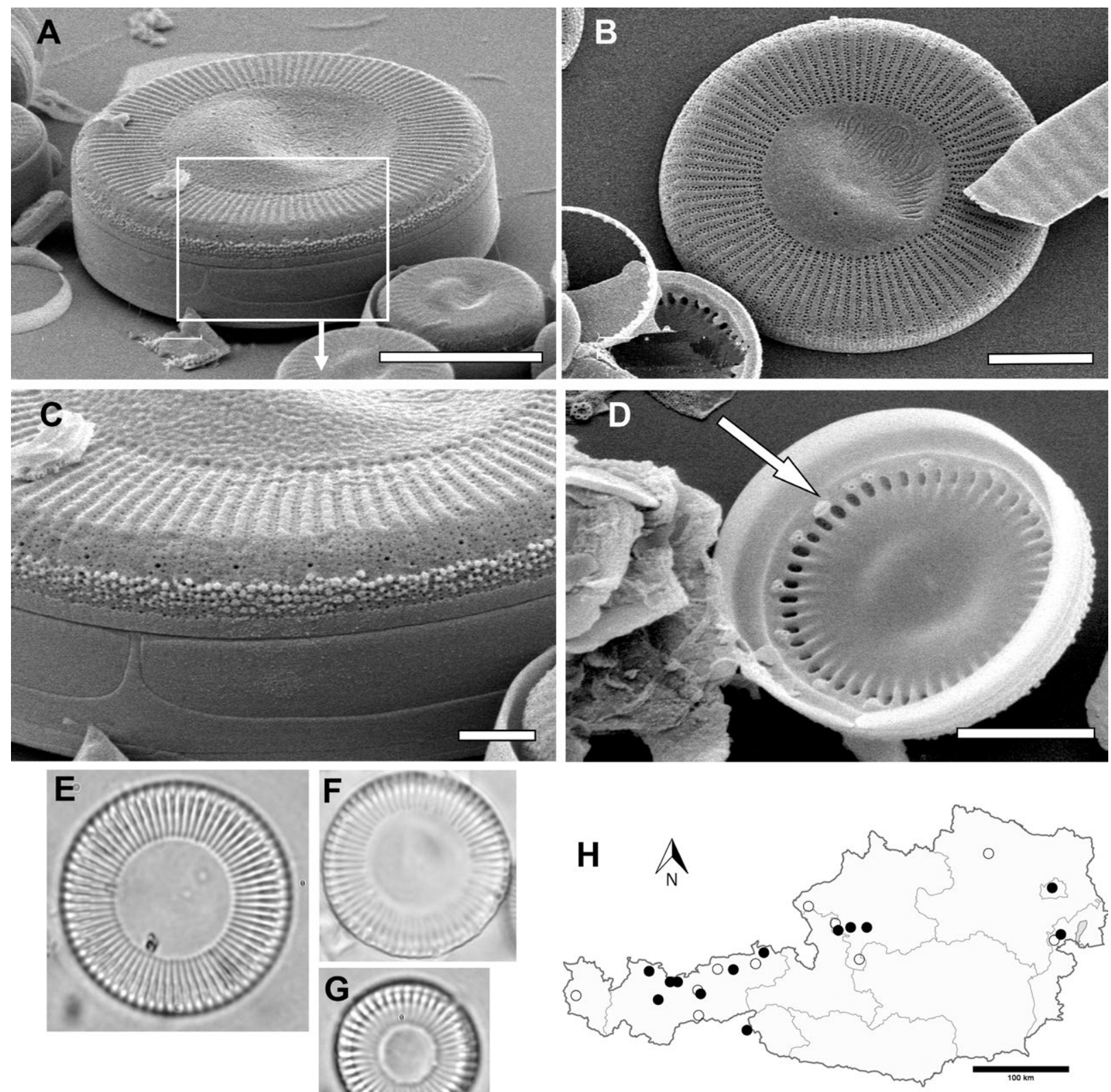

Figure 9. Cyclotella distinguenda. A-D - scanning electron microscope images (A-B: typical external views with circular central area with sigmoid waving and irregular scrobiculations; C: marginal fultoportulae situated under costae at variable distances (below every $4^{\text {th }}$ or $5^{\text {th }}$ costa; arrow in D: one rimoportula positioned on the same place as marginal fultoportulae); $\mathrm{E}-\mathrm{G}$ - light microscope images show large frustule size variation; $\mathrm{H}-$ sampling records (black points). Scales: $\mathrm{A}=10 \mu \mathrm{m} ; \mathrm{C}=2 \mu \mathrm{m} ; \mathrm{B}, \mathrm{D}, \mathrm{E}-\mathrm{G}=5 \mu \mathrm{m}$. 
Notes. This is the second most common planktonic centric of lakes in Austria, originally described from a lake sediment core of Lunzersee Lower Austria (Hustedt 1927). It seems to favor oligo- to mesotrophic lakes. It can be found all year round, but shows best proliferations in later summer and autumn.

\section{Cyclotella meneghiniana Kützing 1844 (Fig. 10A-H)}

Description. The cylindrical frustules (10-24 $\mu \mathrm{m}$ in diameter) are characterized by regular broad radial undulations (Fig. 10A, E-G), reaching from the valve margins toward the center along a variable portion of the radius ( $1 / 2$ to $2 / 3$ of the distance). These structures are related to the internal areolae leaving a circular, unstructured, somewhat wavy central area open. The central area is ornamented by (1) 2-3 fultoportulae with three satellite pores (Fig. 10B-C) sometimes visible in the LM (all in Fig. 10E-G). The interior view of the frustules shows the regular positioning of fultoportulae most frequently on all ribs except one, which is holding one distinct rimoportula in the same position as the marginal fultoportulae (arrow Fig. 10D). The margin of the outside view of the frustule (Fig. 10A) shows somewhat irregularly arranged small spines situated in the depressions between the raised parts and related to the external opening of the marginal fultoportulae external openings. The diameter can vary widely (Fig. 10E-G). We recorded smaller individuals than given in literature (10-24 $\mu \mathrm{m} ; 7-8 \mathrm{ribs} / 10 \mu \mathrm{m})$.
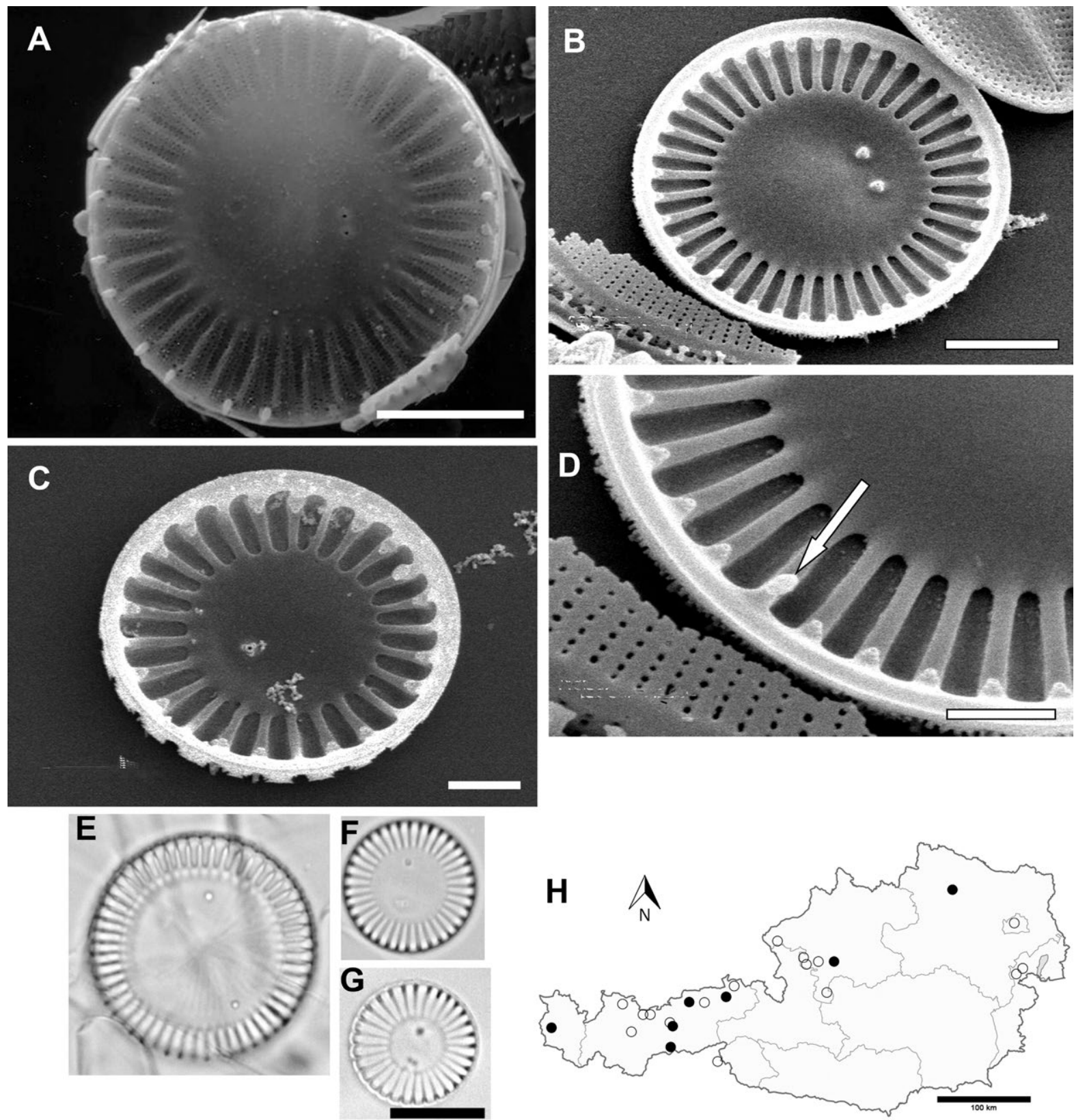

Figure 10. Cyclotella meneghiniana. A-D - scanning electron microscope images; (A: note the regular marginal ring of costae related to internal alveolae; B-D: every costa has one distinct marginal fultoportula except one replaced by one rimoportula; the one to two central fultoportulae have three satellite pores); $\mathrm{E}-\mathrm{G}$ - light microscope images show variable extension of central area. $\mathrm{H}$ - shows scattered sampling record locations. Scales: $\mathrm{A}-\mathrm{B}=5 \mu \mathrm{m} ; \mathrm{C}-\mathrm{D}=2 \mu \mathrm{m} ; \mathrm{E}=10 \mu \mathrm{m}$. 
Notes. This is a very widespread taxon, which was found here in nutrient rich (eutrophic) sites (Fig. 10H).

Discostella stelligera (Cleve \& Grunow) Houk \& Klee 2004 s.lat.

(Fig. 11A-G)

Description. This species complex can harbor several taxa (e.g., D. glomerata, pseudostelligera, stelligera). We therefore give a broader general characterization as follows: frustules cylindrical or drum shaped 5-12 $\mu \mathrm{m}$ in diameter. The valve face has a small convex central area on the epivalve (Fig. 11A, C) and a corresponding depression on the hypovalve (Fig. 11B). The central area has variable structure with star-shaped internal depressions (interior view) or inflations (external view) easily visible in the LM (Fig. 11E-F). The rows of areolae (normally two forming one stria; 45-60 areolae/10 $\mu \mathrm{m}$ ) and the shape and size of those in the striae are somewhat irregular. The interfascicles (costae) are robust and can branch toward the mantle, as shown on the auxospore in Fig. 11D, so that the fultoportulae (with two satellite pores) situated on the branches seem to be positioned within the costae like interstriae. The mantle areolae are more regular, but smaller in size than those on the striae. Striae $(12 / 10 \mu \mathrm{m})$. From the interior, the interstriae look like costae surrounding alveolar chambers. Fultoportulae are found on every $1^{\text {st }}-3^{\text {rd }} \operatorname{costa}$ (Fig. $\left.11 \mathrm{C}-\mathrm{D}\right)$.

Notes. Common and widespread taxa complex in lakes, occurring often more frequently near the sediment so that it is a common benthic taxon (see Catalan et al. 2013) or at least a so-called tychoplanktonic species (this is why
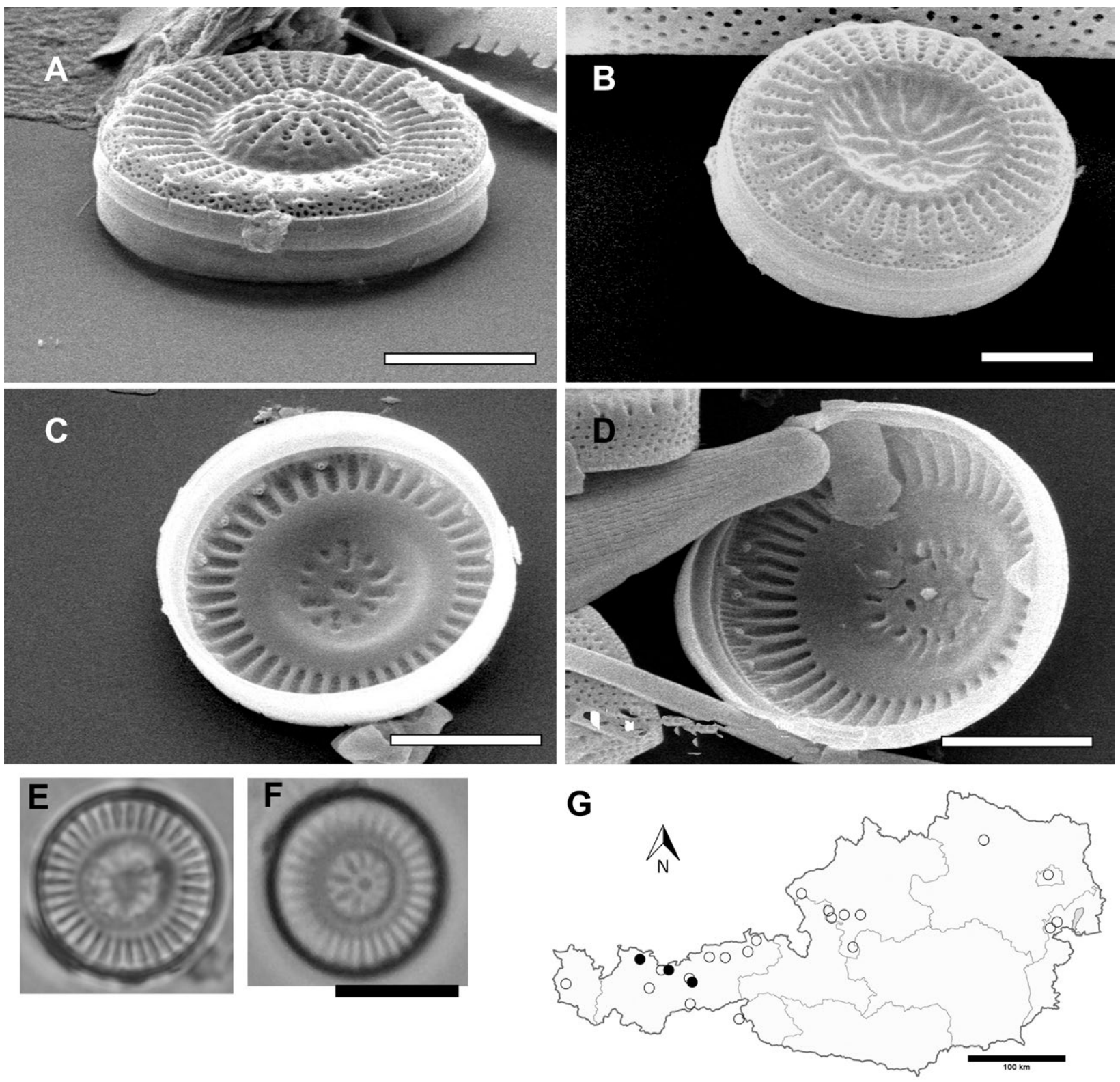

Figure 11. Discostella stelligera s.lat. A-D - scanning electron microscope images of (A-C: vegetative frustules; exterior view of A: epivalve with central inflation, B: centrally depressed hypovalve; and C-D: interior views with irregular star-like ornamentation of central area; C: a ring of marginal fultoportulae is related to first side branches of every second or third costa; D: this is particular striking with the inflated valve of a presumably pre-auxospore stage); E-F - light microscope images showing structural variability; G - sampling record locations (black points). Scales: $\mathrm{A}-\mathrm{F}=5 \mu \mathrm{m}$. 
it is underrepresented in Fig. 11G). There is a large form variability and also variation in growth-form types (chains typical for the similar or often smaller D. glomerata, also found in D. pseudostelligera which has a less differentiated star-like valve center) and unclear relations to taxa like $D$. pseudostelligera. These are two key examples of potentially several additional eco-morphs or species within this species group (e.g., 11B vs 11C). Trophic preferences due to divergent ecology unclear.

Lindavia austriaca (Peragallo) Nakov, Guillory, Julius, Theriot \& Alverson 2015

(Fig. S2)

Description. Cell shape outline elliptical to slightly rhombic, symmetric to main axis lateral inflation, 20-43 $\times 8-18 \mu \mathrm{m}$. Marginal striation fine $25-27 / 10 \mu \mathrm{m}$. Central area with drop-like points approx. $13 / 10 \mu \mathrm{m}$. The marginal ring of striae bears thickened striae with 9-12 thinner striae in between.

Notes. This taxon was studied in detail using SEM by Houk et al. (2010) from Fuschlsee (Upper Austria). We found this taxon only sporadically so could not study it with SEM. It is supposed that this taxon bears all typical features of the taxa around Lindavia (central field with areolae with domed cribrum). Likely an organism preferring oligotrophic larger lakes (see also sampling locations by Houk et al. 2010 in Austria). Lindavia tenuistrata is another rare species (Table S1) with very short thickened lateral striae (LM) of same ecology and regional dispersion only found toward the end of this study.

Lindavia balatonis (Pantocsek) Nakov Guillory, Julius, Theriot \& Alverson 2015

(Fig. 12A-G)

Description. Cells circular cylindrical, valves with a flat or slightly concave central area (Fig. 12A, E). Although it belongs to the species complex around L. radiosa, it never has a central domed area. Diameter 13-21 $\mu \mathrm{m}$. In the LM, it shows 'Schattenlinien' (Fig. 12F), a feature that was thought to be typical for the 'Cyclotella comta' group (Krammer \& Lange-Bertalot 1991) which appear as dark short forked striae separated by two striae with somewhat irregular endings toward the central area in marginal focus. This feature is referred to the thick costae (ribs) (Fig. 12C-D) which are in fact the robust delimitations of the internal distinct marginal areolae. Those are more robust than in other taxa of this species complex (e.g., missing or open in L. praetermissa!) and separated by one to several thinner costae inside the areolae (Fig. 12C-D). In addition, the marginal striation pattern linked to these costae is interrupted three or four times along the circumference where a shortened stria accommodates one rimoportula (arrow in Fig. 12B). A variable number of small rimoportulae (2-4) are closely related to thinner costae and have one small labiate opening. Fig. 12D white arrows). There is a ring of marginal fultoportulae on every $2^{\text {nd }}, 3^{\text {rd }}$ or $6^{\text {th }}$ broader costa separated in between by (1) 2-3-4 finer costae (Fig. 12D). The central area is somewhat irregular circular delimited and ornamented by a large number of areolae with internally domed cribrum
(Fig. 12C-D), a key feature of the genus Lindavia (see Ács et al. 2016). These areolae are not strictly radially arranged and mixed with granular scrobiculations. In the central area, there is also a larger number of fultoportulae (small circular poroids, Fig. 12C-D) which in the inside view show three satellite pores (arranged somewhat irregularly and subcentral) characterized by smaller openings externally in the SEM (Fig. 12B). The marginal striae are formed by much smaller areolae $(40-60 / 10 \mu \mathrm{m})$ roughly radially arranged into pairs and continuing into the mantle.

Notes. This taxon is common in many lakes in Austria, most frequently recorded from mesotrophic small to mid-sized lakes in summer. It is difficult to differentiate L. balatonis from L. praetermissa in the LM, although the latter has shorter thickened costae (less distinct 'Schattenlinien', a few branched smaller costae), no lateral shortened striae and a somewhat more irregular delimited central area due to frequently uneven central endings of striae towards the central area (see Fig. S1). Widespread taxon with a preference for mesotrophic smaller lacustrine environments, not frequent in Hungarian running waters, although described from Lake Balaton (Kiss et al. 2012).

Lindavia bodanica (Eulenstein ex Grunow) Nakov Guillory, Julius, Theriot \& Alverson 2015 (Fig. 13A-H)

Description. Cells circular discoid cylindrical, normally with slightly convex epivalve (Fig. 13C, E) and slightly concave hypovalve (Fig. 13B). Highly variable size (diameter $12-80 \mu \mathrm{m}$ in literature, here $23-50 \mu \mathrm{m}$ ). Radial striations very regular and thus visible in the LM $(15-17 / 10 \mu \mathrm{m})$ extending into the valve flat for up to $50 \%$ of the radius (Fig. 13F) and from the valve flat into the mantle with somewhat higher number of areolae (as seen in the SEM Fig. 13E). The valve flat marginal area with radially arranged double rows of areolae that can reach three rows near the margin $(55$ areolae/10 $\mu \mathrm{m})$. Usually 2-3-4 lateral rimoportulae with broad internal projections are originating close to shortened lateral striae (Fig. 13E, arrow). The central areolae with domed cribrum numerous (25 areolae $/ 10 \mu \mathrm{m})$ leave a central circular hyaline area free of structures that is visible in SEM (Fig. 13A) and LM (Figs 13F-G). Numerous central fultoportulae with three satellite pores were found scattered roughly between the central area structures and are more frequent within the distal half of the central area (Fig. 13A). In the SEM, the distinct open marginal elliptical alveolae show regular bifurcated costae in the interior (Fig. 13D). The costae delimiting the areolae are ornamented by fultoportulae, each with two satellite pores. L. bodanica differs from L. intermedia by cell shape, finer and denser striation and a lower number of areolae on radial striae.

Notes. Characteristic component of oligo to mesotrophic perialpine lakes (Fig. 13H) situated in the center of the study area with a preference for large clean waterbodies (with turbulent water columns). It is one of the largest cyclotelloids in the plankton of freshwater lakes in the Eastern Alps. 

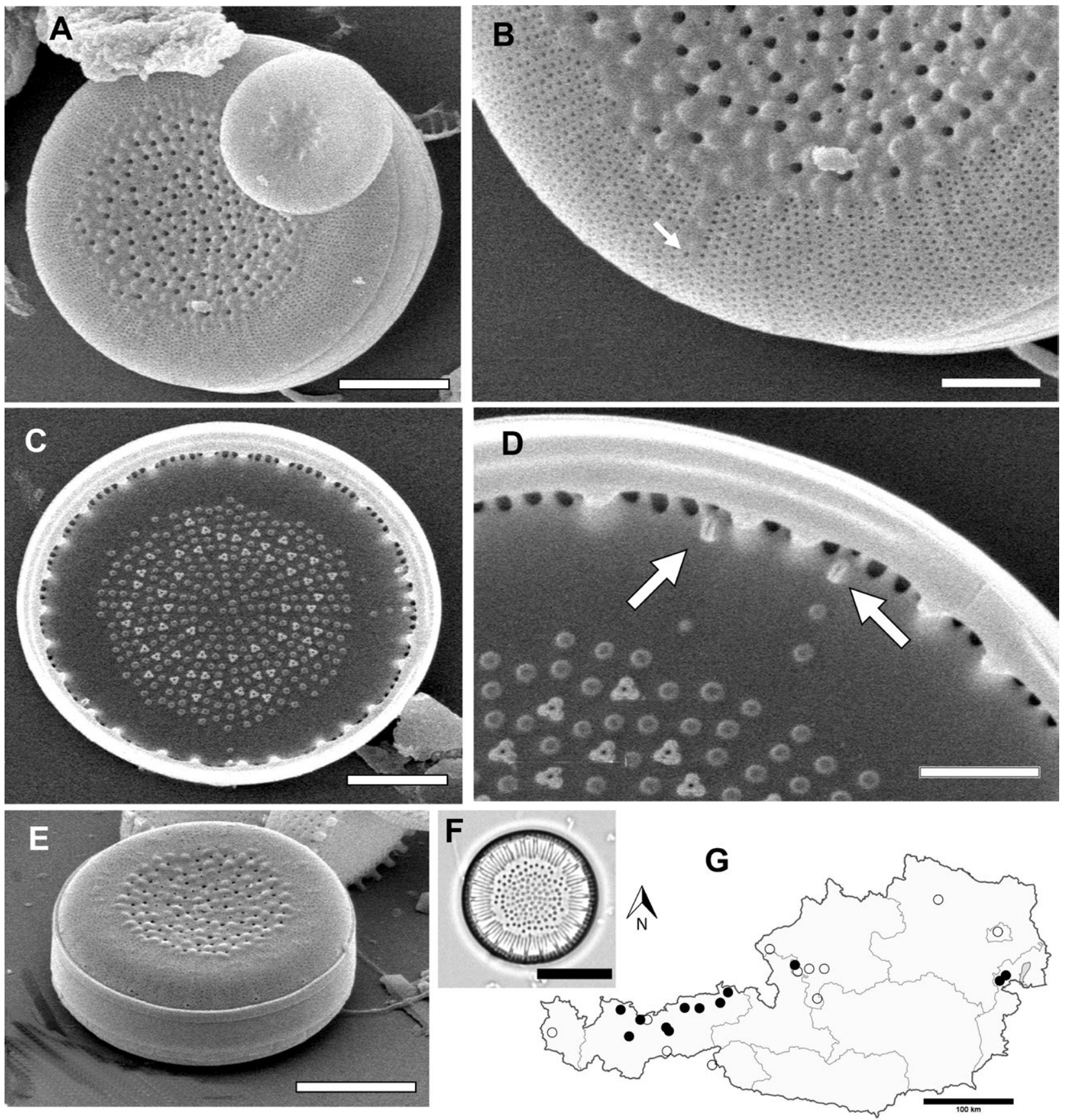

Figure 12. Lindavia balatonis. A-E - scanning electron microscope images of frustules (A, B and E: external views with ring of regular unstructured girdle bands; C, D: internal views with roughly circular central area, ornamented by both small central fultoportulae with three satellite pores and large areolae (with domed cribrum) in the centre arranged roughly radial; the short alveolar chambers are delimited by distinct broader costae, on which the marginal fultoportulae are located, with one to five thinner intercostae in between; arrows in B, D: external and internal view of rimoportula close to the marginal alveolae); $\mathrm{F}$ - light microscope image shows the striking interruption of marginal striation, where single rimoportulae are located; $\mathrm{G}$ - sampling record locations (black points). Scales: A, C, E = 5 $\mu \mathrm{m} ; \mathrm{B}, \mathrm{D}=2 \mu \mathrm{m} ; \mathrm{F}=10 \mu \mathrm{m}$.

Lindavia intermedia (Manguin ex Kociolek \& Reviers) Nakov Guillory, Julius, Theriot \& Alverson ex Daniels, Novis \& Edlund 2016

(Fig. 14A-I)

Description. Large and robust discoid cylindrical frustules (Fig. 14A, C, E; 15-40 $\mu \mathrm{m}$ in diameter) with a very distinct domed or depressed central area, covering approx. $1 / 3$ of the whole diameter (this is very striking in the LM, Fig. 14F-H). The striation and interstriae continue from the mantle to the domed area and along the marginal bifurcation (Fig. 14B). Coarse striation is $11-14 / 10 \mu \mathrm{m}$ composed of triple rows of puncta $(40-50 / 10 \mu \mathrm{m})$. The marginal alveolar chambers interior view shows very similar bifurcated costae, which are more circular and smaller than in Lindavia bodanica. The external openings of the three rimoportulae on the valve flat are situated on somewhat inflated areas and delimited by shortened striae (Fig. 14A-B). The central area bears a larger number of fultoportulae with three satellite pores (Fig. 14D).

Notes. This taxon has been studied in detail by Houk et al. (2010) from Hallstättersee, the site observed here again. In $\mathrm{N}$-America and elsewhere, it has been recorded from artic latitudes mainly (Daniels 2012). Typical component 

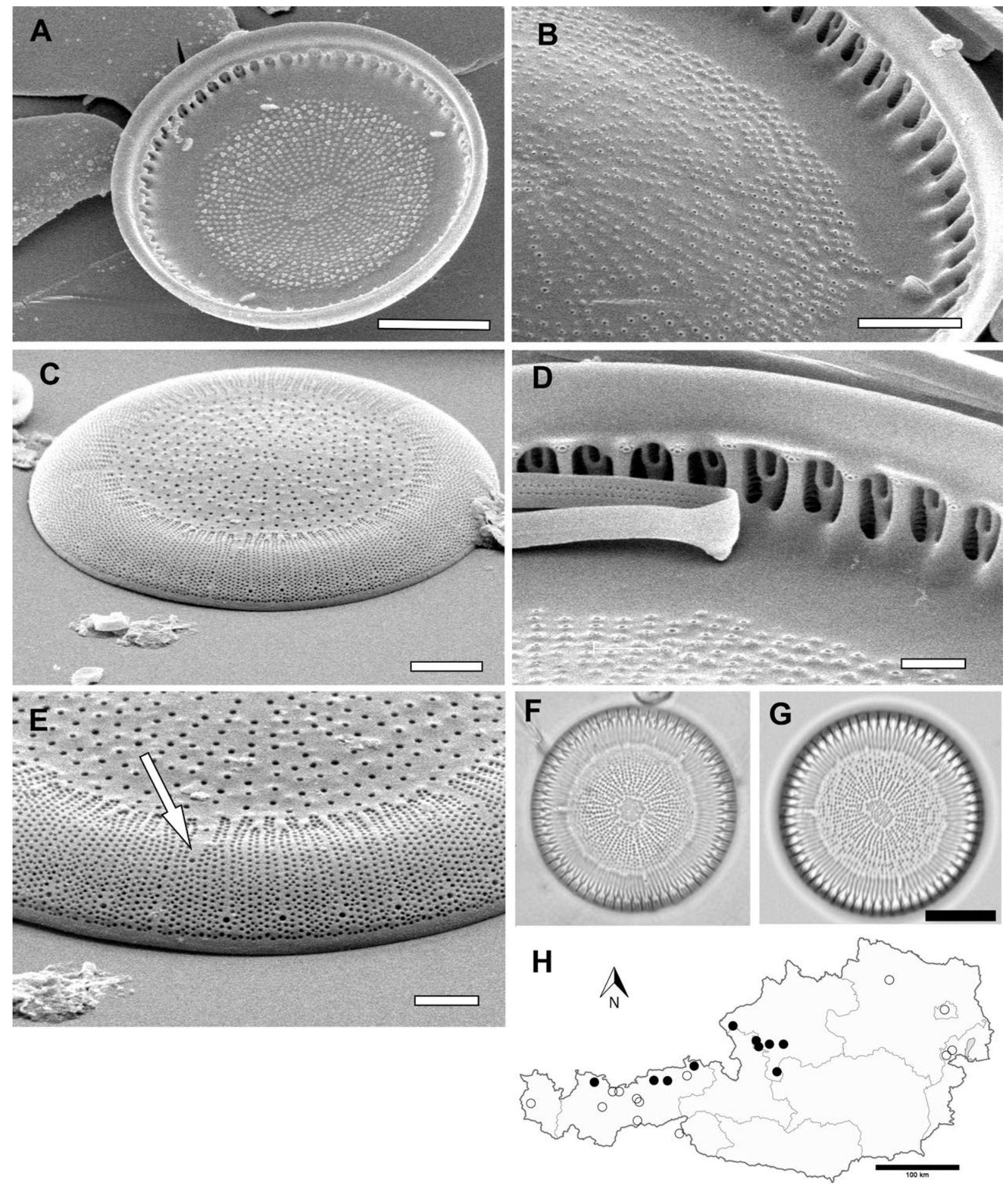

Figure 13. Lindavia bodanica. A-E - scanning microscope images (A-B, D: interior views of valves; B, D: striking marginal alveolar chambers with interior bifurcated costae; A, C-D: roughly radially arranged numerous perforations with both: areolae with domed cribrum and minute fultoportulae with three satellite pores; E: the composition of marginal striae by double rows of puncta with very minute costae in between, and the stable position of the marginal fultoportulae with three satellite pores are visible; arrow in E: positon of one (or up to three) lateral rimoportulae); $\mathrm{F}-\mathrm{G}$ - light microscope images show a small ring without perforations in the central part of the central area (see also A); $\mathrm{H}-$ shows perialpine sampling record locations. Scales: $A, F-G=10 \mu \mathrm{m} ; \mathrm{B}-\mathrm{C}=5 \mu \mathrm{m} ; \mathrm{D}-\mathrm{E}=2 \mu \mathrm{m}$.

of a few large perialpine oligo- to mesotrophic lakes in Upper-Austria (Fig. 14I).

Lindavia praetermissa (Lund) Nakov Guillory, Julius, Theriot \& Alverson 2015

(Fig. 15A-G)

Description. Cell cylindrical with circular outline (10$30 \mu \mathrm{m}$ in diameter) and a flat central area (Fig. 15A-B).
Central area with thick points (areolae with domed cribrum) and thin points (fultoportulae). The close arrangement of marginal somewhat irregular ending striae $(16-18 / 10 \mu \mathrm{m})$ and the irregular punctuation of the central area are unique, as well as the uneven structureless ring delimited laterally by uneven ending marginal alveolae (Fig. 15C-D). The thicker points (areolae visible in the LM, $12 / 10 \mu \mathrm{m})$, as well as the variable number of 

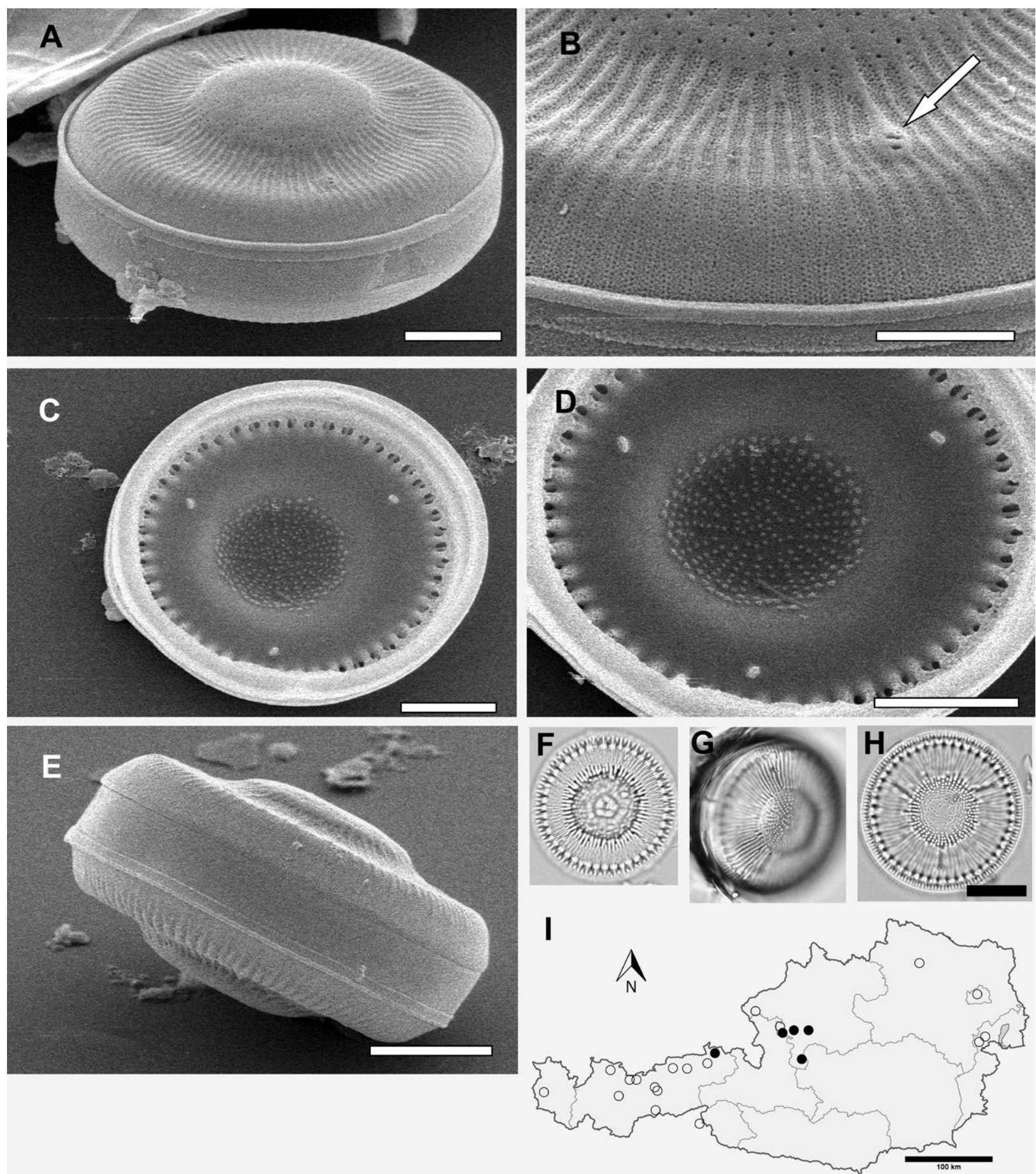

Figure 14. Lindavia intermedia. A-E - scanning electron microscope images show typical shape of the taxon (A: overview; B, E: external details of valve face and girdle bands with central inflation; note the high number of puncta forming marginal striae (3-4-5 rows); in C, D: interior views with ornamention of the central area with perforations, areolae with domed cribrum and a larger number of central fultoportulae with three satellite pores; between the ring of lateral alveolae and the central area 3-4 distinct rimoportulae; E: presumably pre- or postauxospore frustule with central inflation on both valves); G-I - light microscope images showing typical shape; I - shows restricted sampling locations recorded (black points). Scales: A, C-E, G-I $=10 \mu \mathrm{m} ; \mathrm{B}=5 \mu \mathrm{m}$.

slightly thinner costae [(1)-2-3-(4)] between the thicker marginal costae are related to the Schattenlinien in the LM (Fig. 15E). Thick costae bear well marked marginal fultoportulae with two satellite pores and are separated by a variable number of thinner costae of which a few are irregularly bifurcated (Fig. 15C-D). Rimoportulae (1-3) are situated at the end of only slightly shortened striae, distant from the open marginal alveolae (and not closed as in L. balatonis). Although this taxon is close to $L$. radiosa and $L$. balatonis a differentiation in $\mathrm{LM}$ is possible by overall frustule shape, delimitation of central area, different position of rimoportulae and regular closed ring of marginal striation (no shortened striae). Potential infraspecific variability of SEM features (alveolar structures) require further studies since Houk et al. (2010) showed strictly circular terminating alveolar chambers toward the central area. Widespread taxon in Austrian lakes with a preference of oligo to mesotrophic waters. 

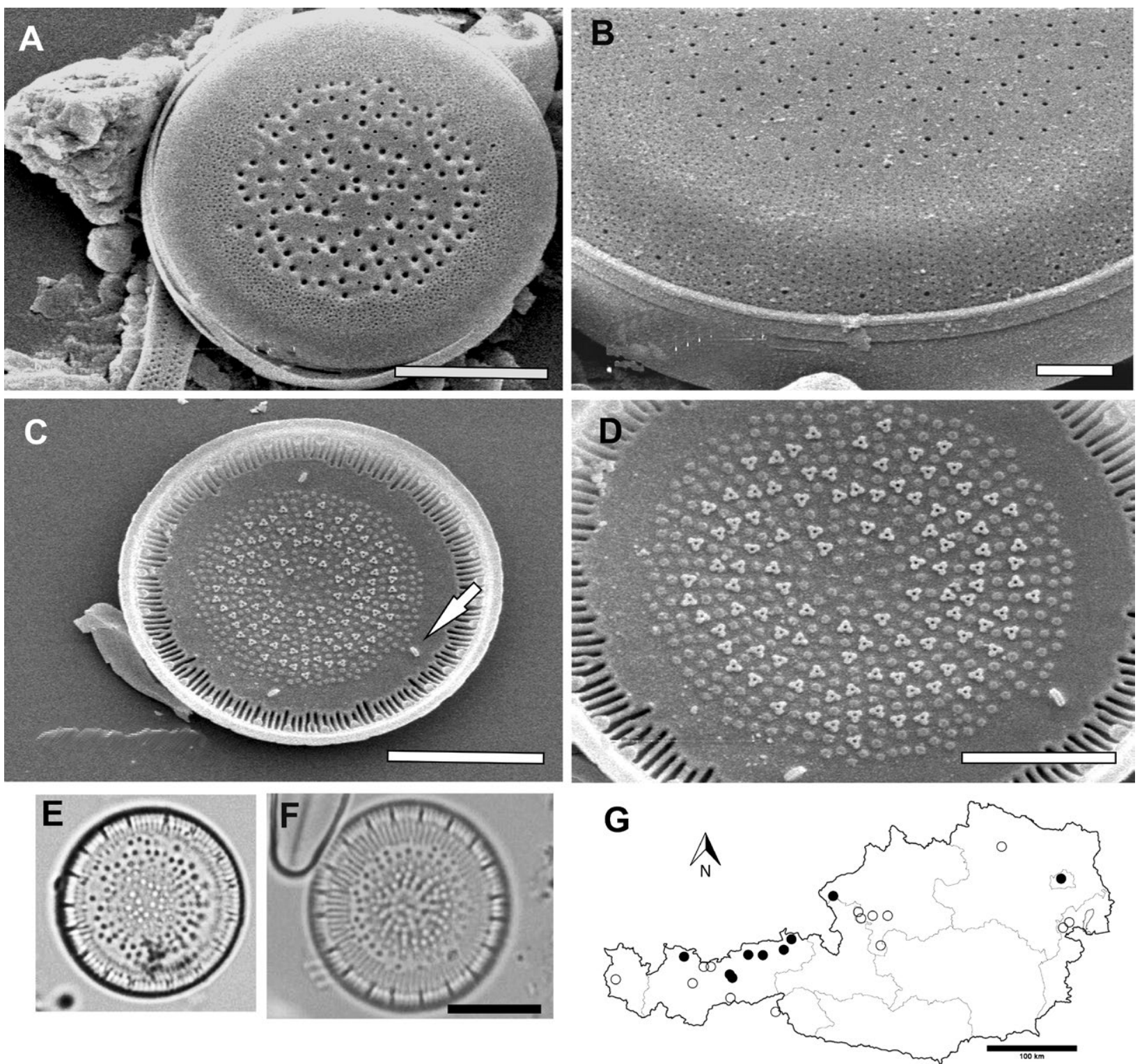

Figure 15. Lindavia praetermissa. A-D - scanning electron microscope images (A-B: exterior of frustules with even dispersed puncta of two types in central area: large points (areolae with domed cribrum) and numerous small points (central fultoportulae with three satellite pores) in the internal views in $\mathrm{C}$ and $\mathrm{D}$; arrow in $\mathrm{C}$ : indicates one of three rimoportulae on structureless ring of valve interior; note the irregular delimited central area by uneven ending of radial alveolae in $\mathrm{C}-\mathrm{D}$ and marginal fultoportulae on every third to fifth costa); E-F - light microscope images show 'Schattenlinien' related to the marginal fultoportulae and elongated alveolae; $\mathrm{G}$ - sampling record locations (black points). Scales: A, C, $\mathrm{E}-\mathrm{F}=10 \mu \mathrm{m} ; \mathrm{B}=2 \mu \mathrm{m} ; \mathrm{D}=5 \mu \mathrm{m}$.

It has most probably been overlooked or misidentified as several similar taxa within the so-called C. comta group. It seems as if the SEM study of this taxon by in Kiss et al. (2012) is a misinterpretation of this taxon. Fig. 16A-B, D-E of this study show most likely all L. radiosa.

Lindavia radiosa (Grunow) Nakov Guillory, Julius, Theriot \& Alverson 2015

(Fig. 16A-H)

Description. Cylindrical cells $(10-25 \mu \mathrm{m}$ in diameter) with circular outline, well silicified frustules and a more or less well domed central area on the epivalve (Fig. 16A) and a corresponding depression on the hypovalve (Fig. 16C-D). The central area is ornamented by distinctly radial arranged rows of areolae (with domed cribrum) approx. 10-12/10 $\mu \mathrm{m}$, which often become loosely arranged toward the margin. Within these lines of areolae, several central fultoportulae with three satellite pores are scattered (Fig. 16C-D) which appear externally as smaller openings within the larger ones in the central area. Marginal fine striation ends more or less circular leaving between striae and central pore field a narrow unstructured ring of central area open. In the interior view, this open area is where one to three rimoportulae are situated (variable positions in Fig. 16C-D). The inside view in SEM shows the very regular positioning of marginal alveolae delimited by robust costae each with a distinct fultoportula and separated by thinner costae (3-4) in between. The star-like (radiating) ornamented center is very striking in the LM (Fig. 16E-G).

Notes. This species is widespread in oligo- and mesotrophic lakes in Austria (Fig. 16H), but it is never a dominant component of phytoplankton. Rare and confined 

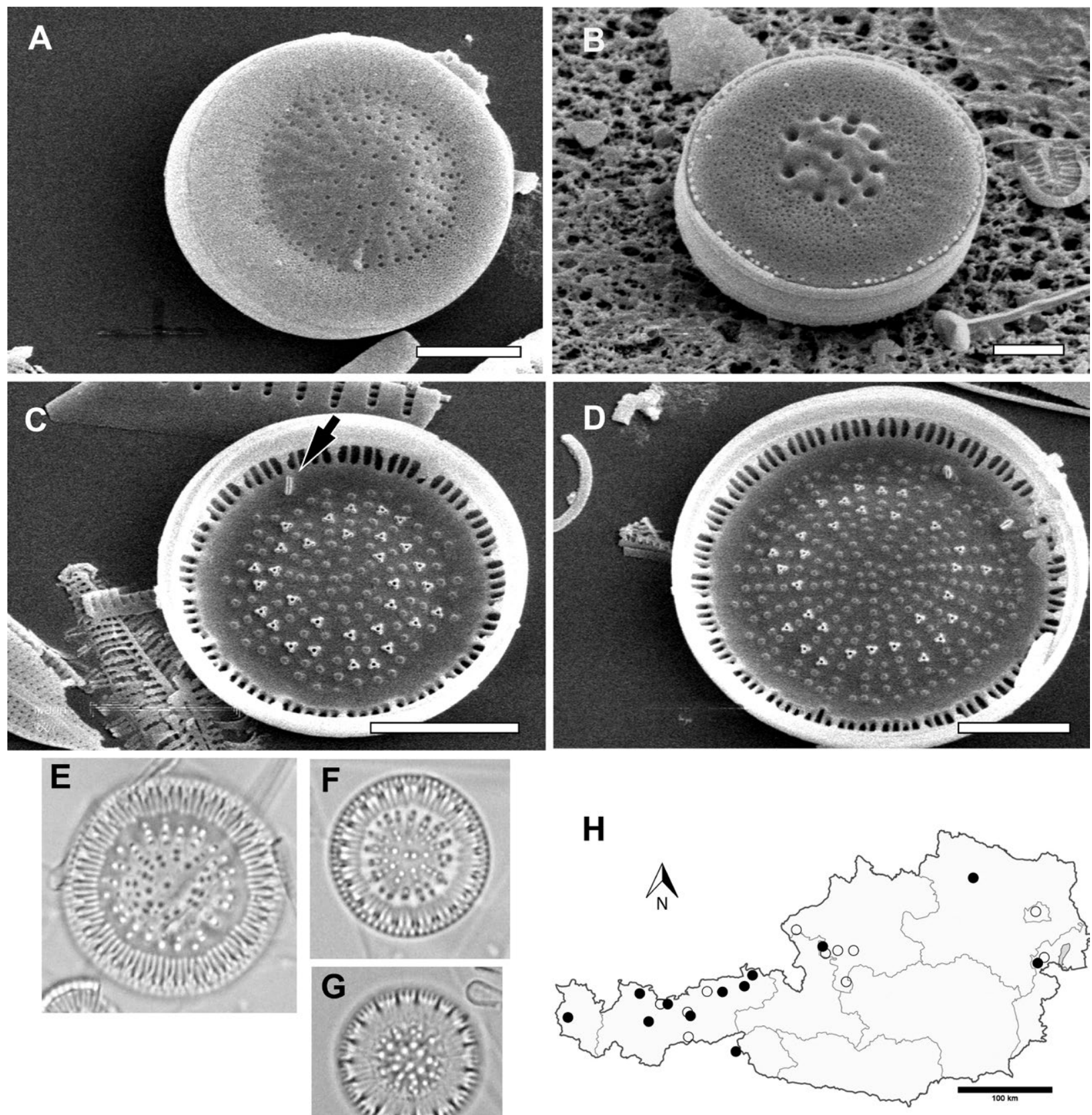

Figure 16. Lindavia radiosa. A-E - scanning electron microscope images (A-B: striking radial arranged large and small points on distinct circular central inflated areas; C-D: interior views show the large points related to areolae with domed cribrum and small points as numerous dispersed minute fultoportulae with three satellite pores and the distinct radial arranged marginal alveolae with every fifth costa strengthened and ornamented by lateral fultoportulae; black arrow in C: example of irregular arranged rimoportulae very close to the lateral ring of alveolar chambers); $\mathrm{E}-\mathrm{G}$ - light microscope images with typical radial central arrangement of puncta and 'Schattenlinien' appearing somewhat remote from the margin or star-like in marginal focus); $\mathrm{H}$ - sampling record locations (black points). Scales: A, C-D $=5 \mu \mathrm{m} ; \mathrm{B}=2 \mu \mathrm{m} ; \mathrm{E}-\mathrm{G}=10 \mu \mathrm{m}$.

to oligotrophic remote lakes of North America (Bahls 2013), but it was also studied in more detail from presumably temperate NE China mountain lakes (Rioual et al. 2017).

Lindavia styriaca (Hustedt) Nakov Guillory, Julius, Theriot \& Alverson 2015

(Fig. 17A-F)

Description. Cylindrical cells $(20-30 \mu \mathrm{m}$ in diameter) with a fine striation $(20-22 / 10 \mu \mathrm{m})$ which extends to $1 / 3$ or less of the radius into the center with additional regular very short thick marginal costae (Schattenlinien) separated by a low number (often only 1-2 (rarely 3 )) of thinner costae (Fig. 17A-B and LM in 17C). Thick costae (rarely neighboring or separated by 1 to 2 thinner costae) bear the marginal fultoportulae (two satellite pores) and form a regular ring of dark points along and very close to the valve margin (visible in LM Fig. 17C). The central area holds a large number of minute points formed by areolae with domed cribrum with a roughly radial arrangement, as well as central fultoportulae with three satellite pores (LM Fig. 17B). 2-3 rimoportulae are situated at irregular distance from marginal alveolae in interior view in the unstructured area between alveolae and central pore field (Fig. 17B). In the SEM and LM 

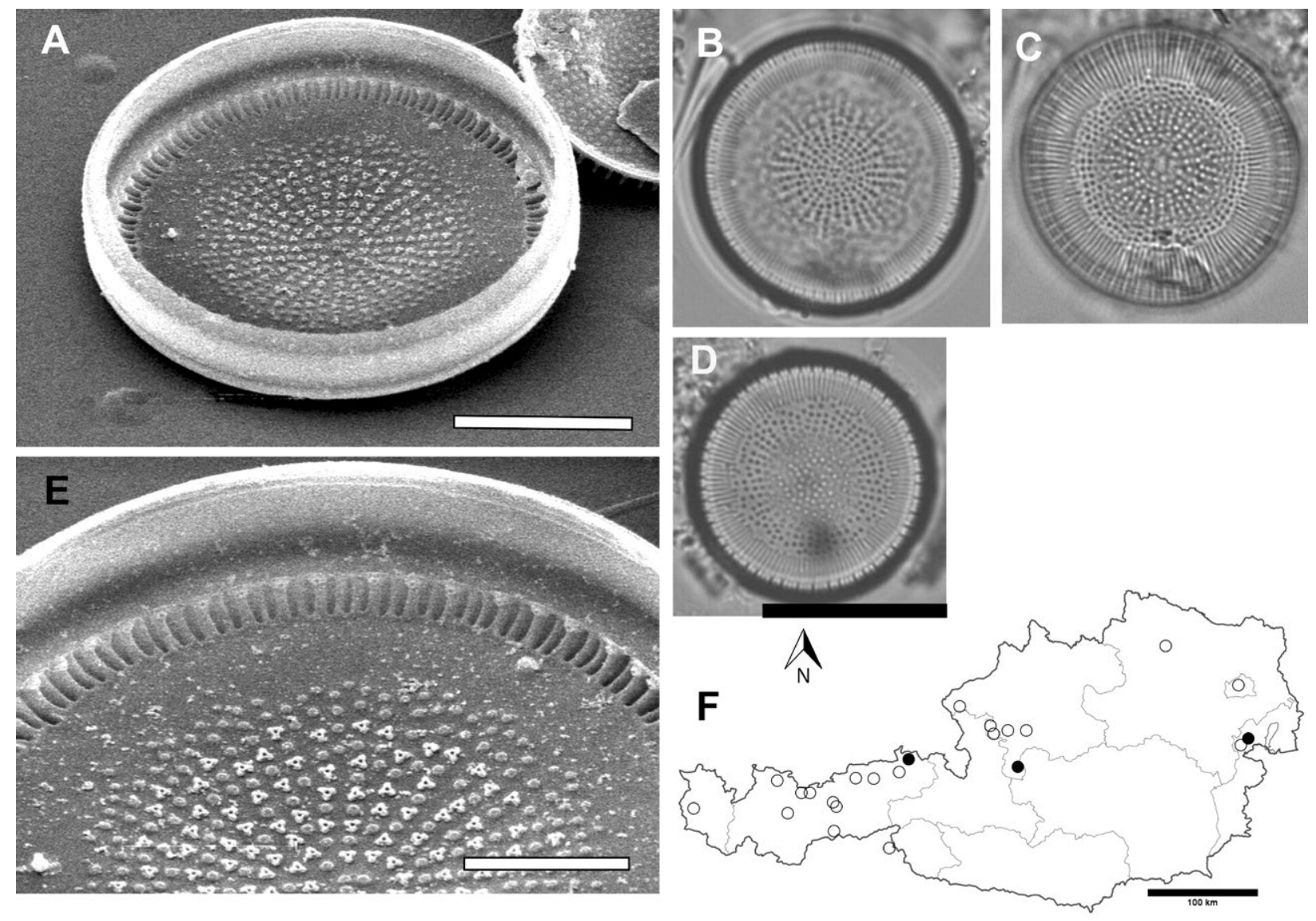

Figure 17. Lindavia styriaca. A, E - scanning electron microscope images (A, E: overview and detail of interior of valve with very short lateral ring of alveolae and a dense ring of marginal fultoportulae (on every second to third costa); the high number of tiny perforations arranged radially are striking (composed by both minute central fultoportulae with three satellite pores and numerous areolae with domed cribrum)); B-D - light microscope images show short marginal striae related to the numerous marginal fultoportulae. $\mathrm{F}$ - shows dispersed sampling locations (black points). Scales: A, $\mathrm{E}=10 \mu \mathrm{m} ; \mathrm{B}-\mathrm{D}=5 \mu \mathrm{m}$.

(thicker lines in Fig. 17B, D), the high number of marginal fultoportulae is striking.

Notes. This taxon with wide and flat or slightly convex cylindrical cells has rarely been recorded (Houk et al. 2010) (20-40 $\mu \mathrm{m}$ in diameter) although originally described from Austria. We sampled it from near the surface in March 2015 in Hallstättersee. In this sample, we also found Lindavia tenuistriata (Table S1).

Pantocsekiella comensis (Grunow in Van Heurck) Kiss \& Ács 2016 s.lat.

(Fig. 18A-J)

Description. The genus Pantocsekiella was described by Ács et al. (2016) with both a clear delimitation by morphological and ultrastructural criteria, as well as by molecular markers. From Lindavia, the closest taxon, it differs by the absence of central domed areolae. However, the delimitation of the infrageneric entities within the genus Pantecsekiella is still difficult, especially in view of the high variability of morphological and ultrastructural criteria, as well as molecular criteria (Kistenich et al. 2014). We show here examples of what we think represent at least three ecomorphs with distinct differences in LM and SEM criteria. The shared features are: cells cylindrical with circular cross section $(4-14 \mu \mathrm{m})$ with somewhat variable central area with some granulations or star-like convex structures (Fig. 18F, I), and sometimes only irregularly scrobiculated (as seen in Fig. 18A and Fig. 18G-H) or colliculate (Fig. 18C). The striation is fine $(18-24 / 10 \mu \mathrm{m})$ and varies frequently from regularly thicker to thinner and the striae endings to the center are somewhat variable in length. The striae consist of double rows of fine areolae (up to $60 / 10 \mu \mathrm{m}$ ). Sometimes the costae are ornamented by granula (Fig. 18A). The central area harbours in all cases one central fultoportula with two satellite pores not easily distinguishable in LM. The interior view in SEM is somewhat variable. It can show small circular (Fig. 18B) to elliptic (egg-shaped) marginal alveolae (Fig. 18E) delimited by costae or even prominent costae (Fig. 18E) (every $4^{\text {th }}$ to $5^{\text {th }}$ somewhat depressed to the side $=$ depressed ribs in Houk et al. 2010). Every $4^{\text {th }}, 5^{\text {th }}$ or $7^{\text {th }}$ costa bears one marginal fultoportula with two satellite pores.

Notes. Very widespread and morphotype rich taxon especially from small and slightly eutrophic lakes (Fig. 18H). The form-type with the butterfly-like shading in the center is more common in small lakes, the larger scrobiculated one (pseudocomensis in the sense of Kistenich et al. 2014) is more common in the larger inneralpine and large perialpine lakes, that corresponds with the findings by Houk et al. 2010. 

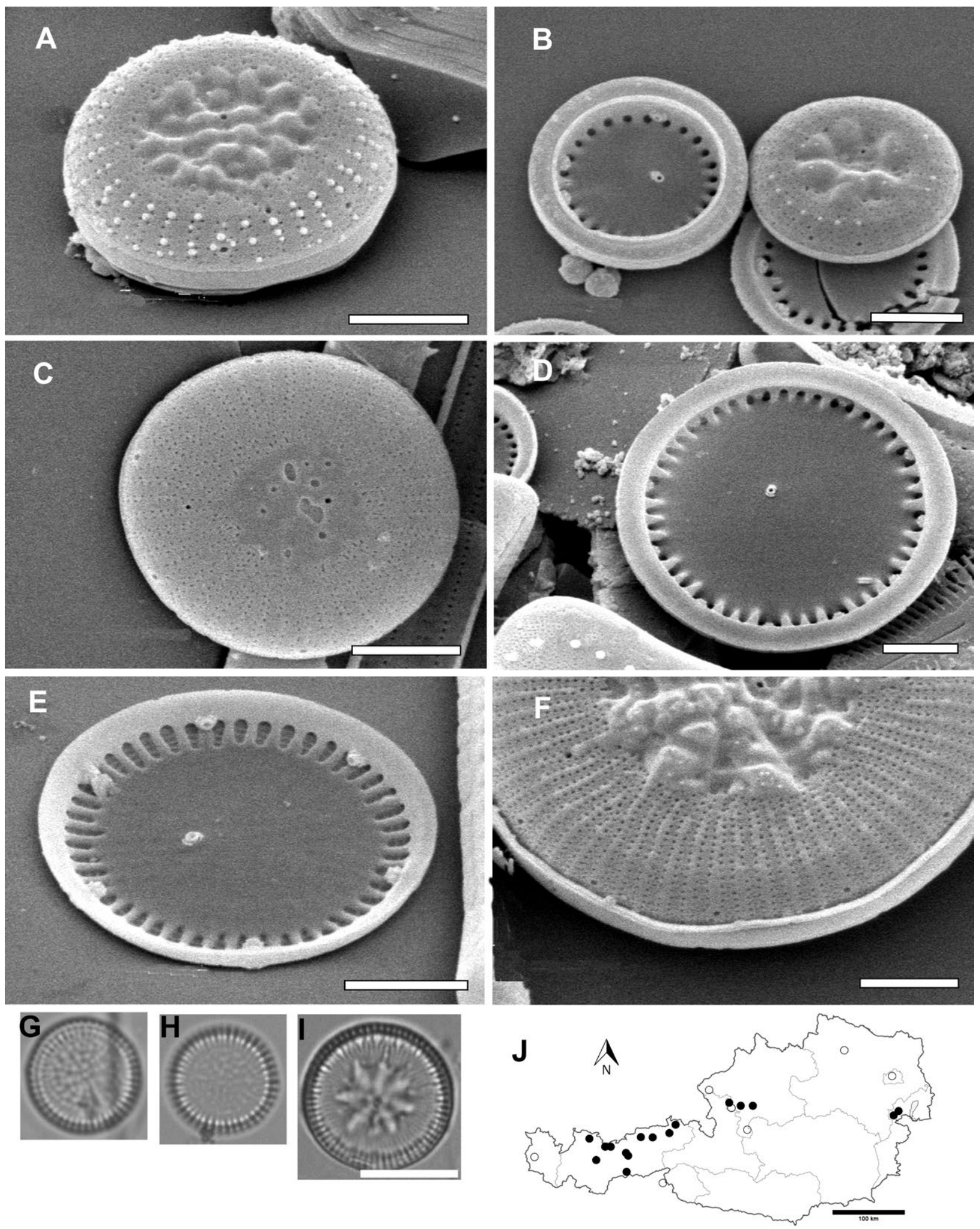

Figure 18. Pantocsekiella comensis s.lat. A-F - scanning electron microscope images and $\mathrm{I}-\mathrm{G}$ light microscope images show different aspects of closely related taxa (A, B: morphotype with scrobiculated central area (also light micrographs in G-H), C-D: morphotype with flat valves and irregular delimited and ornamented central area and E-F: morphotype with star-like central area ornamentation (light microscope image I) in external and B, D-E in internal views; all taxa share the central position of one fultoportula with two satellite pores, the lateral position of one rimoportula close to or on one costa and the positon of lateral fultoportulae mostly on every $6^{\text {th }}$ costa (D-E); the lateral alveolar structures vary from almost open (in D), to small circular closed (B) to elongated egg-shaped in (E); J - dispersed sampling records (black points). Scales: $\mathrm{A}-\mathrm{F}=2 \mu \mathrm{m} ; \mathrm{G}-\mathrm{I}=10 \mu \mathrm{m}$. 
Pantocsekiella costei (Druart et Staub) Kiss \& Ács 2016

(Fig. 19A-I)

Description. Small cells cylindrical with circular outline (5-15 $\mu \mathrm{m}$ in diameter) with a distinct unstructured flat central area with normally one distinct isolated point well visible in both SEM (Fig. 19A-C) and LM (Fig. 19D-H). Central fultoportula with two satellite pores. Striation fine $(18-20 / 10 \mu \mathrm{m})$ with somewhat irregular endings toward center. Striae are formed by double rows of very fine areolae $(65 / 10 \mu \mathrm{m})$ widening into three rows on the shoulder of valve into the mantle (Fig. 19C). Internally there are distinct blunt costae that are eventually integrated into small circular areolae. The thickest (normally every $4^{\text {th }}, 5^{\text {th }}$ or $6^{\text {th }}$ ) depressed costae are bearing fultoportulae with two satellite pores. There is one rimoportula connected to one costa or even sitting with the labiate opening along the costa as seen in SEM from the inside (Fig. 19B). The outside opening is simple.
Notes. This is a very distinct taxon in our experience observed from several Austrian localities (Fig. 19I). It seems to be widespread and potentially cosmopolitan with broader ecological requirements from oligo- to mesotrophic, but also common in high mountain lakes (Koinig pers. comm.), however, it is seen today as conspecific with $P$. comensis based on genetic studies (see discussion).

Pantocsekiella delicatula (Hustedt) Kiss \& Ács 2016

(Fig. 20A-H)

Description. Cells disc shaped cylindrical with regular circular outline (diameter 5-15(23) $\mu \mathrm{m}$ ) and with a typical irregular slightly scrobiculated (or granulated) central area (Fig. 20A, C) of very variable outline caused by irregular length and bending of striae oriented toward the central area and covering a large part of the diameter (up to 2/3) (Fig. 20E). Fine striation (18-21 striae/10 $\mu \mathrm{m})$
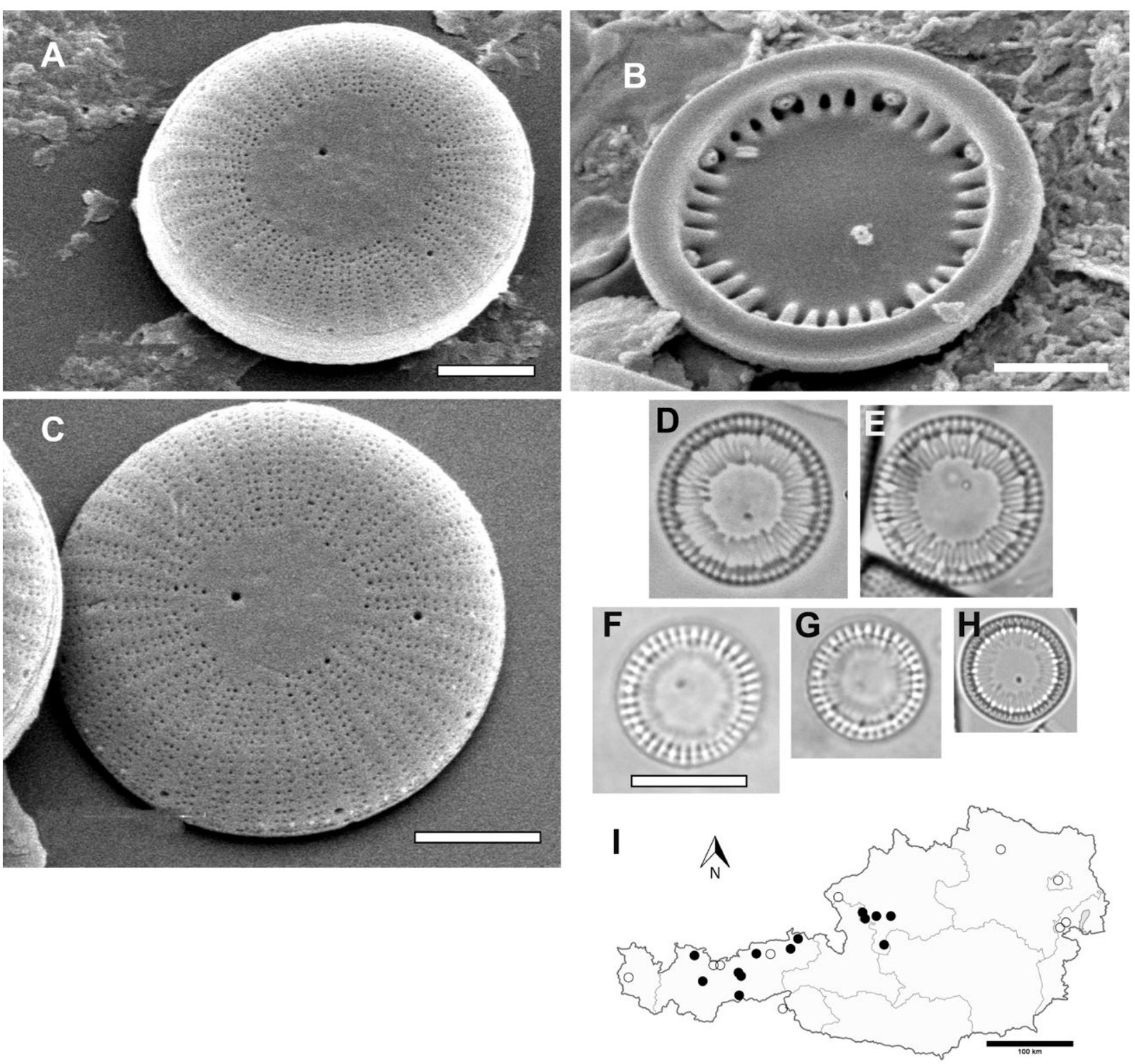

Figure 19. Pantocsekiella costei. A-C - scanning electron microscope images (A: external and B: internal view of valves with typical flat central area with one distinct central fultoportula (two satellite pores) and one lateral rimoportula; the lateral ring of fultopotulae is situated on every $4^{\text {th }}$ to $6^{\text {th }}$ somewhat depressed costa); D-H - light microscope images show variability, exept the striking central point and the regular arrangement of lateral points (fultoportulae); I - dispersed sampling records (black points). Scales: A-C $=2 \mu \mathrm{m} ; \mathrm{E}-\mathrm{I}=10 \mu \mathrm{m}$. 

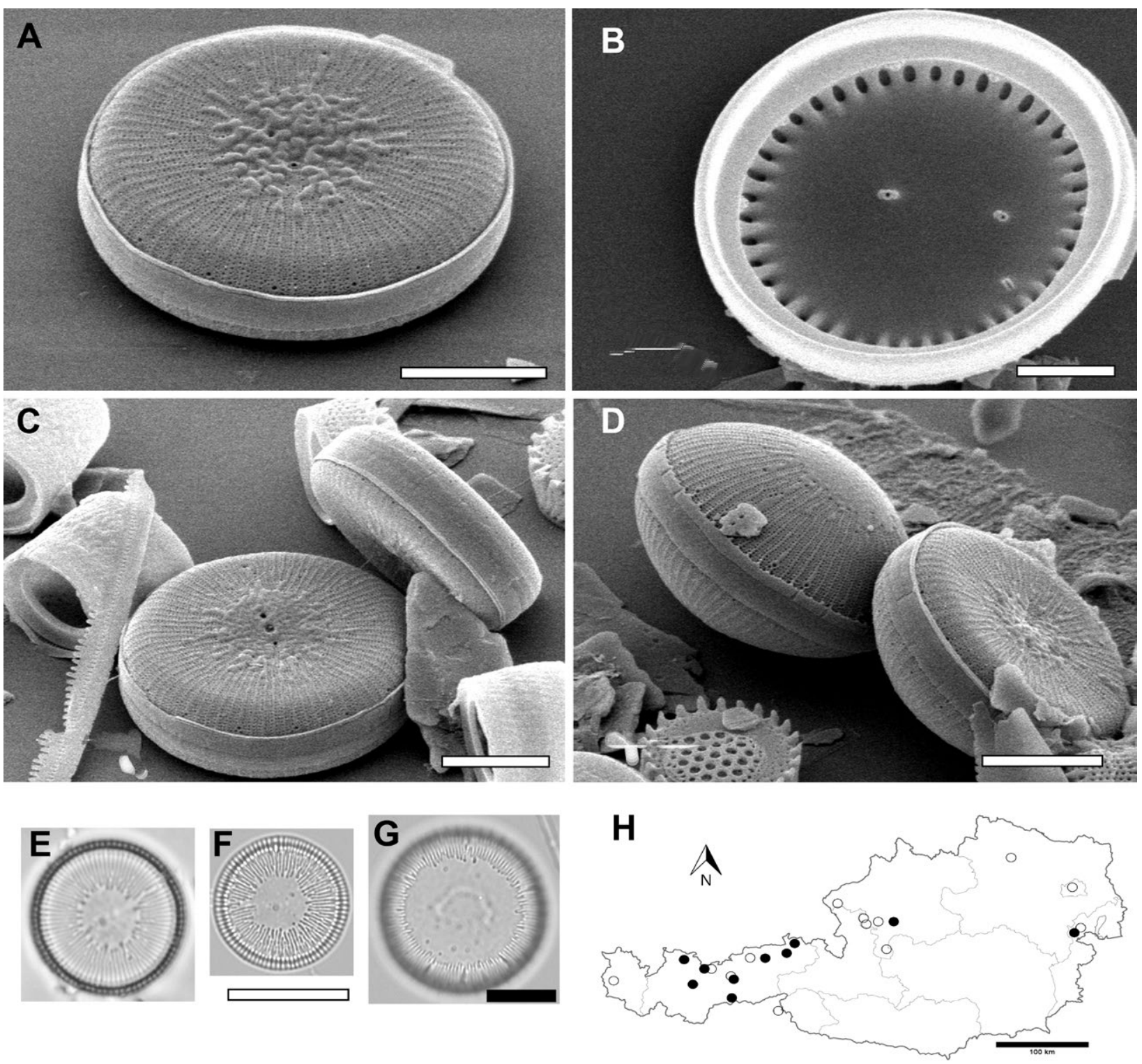

Figure 20. Pantocsekiella delicatula. A-D - scanning electron microscope images (A, C: valve views of complete frustules show the typical flat discoid vegetative morphotype; the central area somewhat scrobiculated; B: the central area interior shows two central fultoportulae with two satellite pores, one, minute lateral rimoportula and a regular ring of marginal fultoportulae on every $5^{\text {th }}$ costa; D: an inflated auxospore and a heterovalvate specimen are shown); $\mathrm{E}-\mathrm{G}$ - light microscope images (G: inflated auxospore with widened central area); $\mathrm{H}-$ dispersed sampling records. Scales: A, C-D $=5 \mu \mathrm{m} ; \mathrm{B}=2 \mu \mathrm{m} ; \mathrm{E}-\mathrm{H}=10 \mu \mathrm{m}$.

composed of double rows of minute areolae (approx. $60 / 10 \mu \mathrm{m})$ and separated by thin interstriae. The marginal costae delimit small circular to elliptical alveolae (Fig. 20B). Every 3-5 (6) ${ }^{\text {th }}$ costa is ornamented by one marginal fultoportula with two satellite pores with simple outside opening reaching the edge of the valve into the mantle. The central area does not show any areolae but 1-2 central fultoportulae with two satellite pores. One rimoportula is situated close to the lateral ring of costae. Auxospore-like stages with inflated cell bodies in Fig. 20D and heterovalvate initial cells show the same fine structure as vegetative cells, but can have a larger unstructured central area (Fig. 20G). In this taxon, dislocations of the valve center and thus non-symmetric (radial dislocated) striation were observed. All observations correspond to the study of Hustedt's materials from the Eastern Alps (Niederösterreich) by Scheffler, Houk and Klee (2003).
Notes. This is a wide-spread taxon of the lake phytoplankton in Eastern Alpine lowland lakes (Fig. 20H). It tends at times to dominate mainly in meso- to eutrophic standing waters, potentially an eutraphentic taxon.

\section{Pantocsekiella kuetzingiana (Thwaites) Kiss \& Ács 2016}

(Fig. 21A-I)

Description. Cylindrical cells with circular outline [(10)15-30 $\mu \mathrm{m}]$ and with an open (= unstructured), but generally very variable, outlined central area due to the variable length and ending of the fine marginal radial striation (15-18 striae/10 $\mu \mathrm{m}$, Fig. 21A, F). The striae are composed of triple to double lines of small areolae $(75-85 / 10 \mu \mathrm{m})$ on the valve flat margin, separated by interstriae (Fig. 21A) which look robust in the interior view. Every $2^{\text {nd }}-3^{\text {rd }}$ costa bears one marginal fultoportula with two satellite pores (Fig. 21C). From the shoulder 

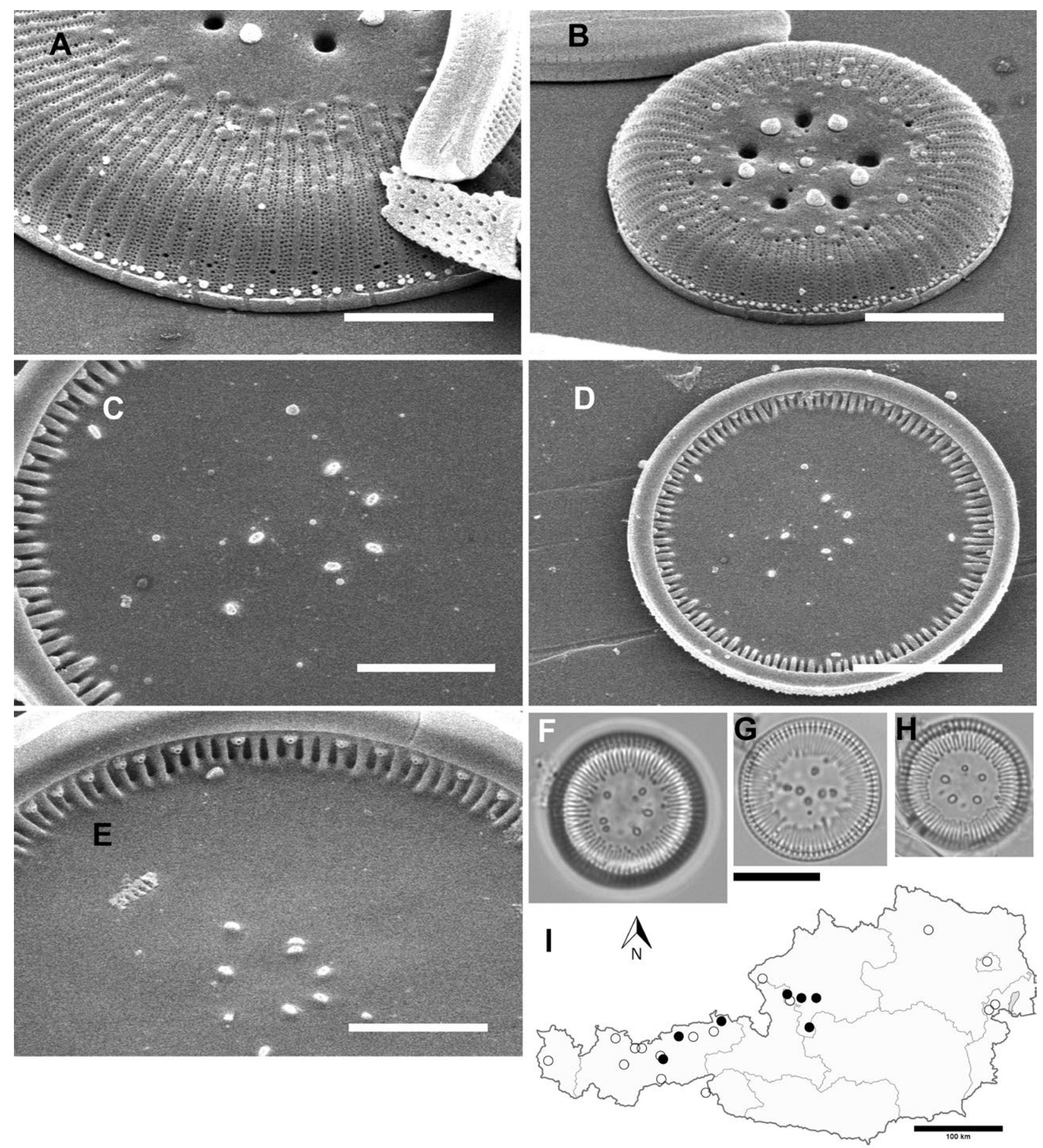

Figure 21. Pantocsekiella kuetzingiana. A-E - scanning electron microscope images (A-B: external view of valve flat with typical grooves and granulations (often five or more) irregular ending marginal striation pattern with striae composed of three rows of puncta; C-E: interior views with a larger number of irregularly scattered central fultoportulae with two satellite pores and a variable low number of rimoportulae close to marginal costae, but not linked to them; the lateral ring of costae is ornamented on every $2^{\text {nd }}$ to $3^{\text {rd }}$ by fultoportulae with two satellite pores); F-H - light microscope images in different focus; I - dispersed sampling records (black points). Scales: A, C, E = $5 \mu \mathrm{m} ; \mathrm{B}, \mathrm{D}, \mathrm{F}-\mathrm{H}=10 \mu \mathrm{m}$.

of the valve flat to the mantle, the striae change to triple rows following down to the valve margin, where a ring of minute granulae can be found (Fig. 21A). The external ending of fultoportulae (2-8, mostly 5$)$ in the central area is simple (Fig. 21B). On the valve flat, there are several grooves (frequently 5 or more) and larger silica granules (orbiculi sensu Kiss et al. 2016) not clearly related to the number of central fultoportulae. There is one or more rimoportulae situated near the marginal structures of the valve (Fig. $21 \mathrm{C}-\mathrm{D}$ ).
Notes. This species was a typical component of the larger perialpine lakes in Austria (Fig. 21I) and other parts of Central Europe (Houk et al. 2010). It differs from P. delicatula mainly by the larger number of central fultoportulae of the central area and by size, as well as from P. ocellata s.lat. by size and LM aspect, although SEM features show many similarities. 
Pantocsekiella ocellata (Pantocsek) Kiss \& Ács 2016 s.lat.

(Fig. 22A-H)

Description. Cells drumshaped small (mostly 5-15 $\mu \mathrm{m}$ rarely up to $20 \mu \mathrm{m}$ in diameter) with specific ornamentation looking like spherical granuli (orbiculi) and corresponding depressions (orbiculi depressi by Kiss et al. 2012) at the valve face (2-6), the most common number being three (Fig. 22A). Fine striation at the margin of the valve is ending somewhat irregular toward the center (Fig. 22E-G). In SEM, the structures show sometimes three depressions (rarely five as in Fig. 22D corroded valve) in the valve center indicated by undulations, and mostly one central fultoportula with two satellite pores. The one (rarely 2) rimoportula is linked to one costa. The marginal fultoportulae are on every $5^{\text {th }}-6^{\text {th }}$ costa (Fig. 22C).
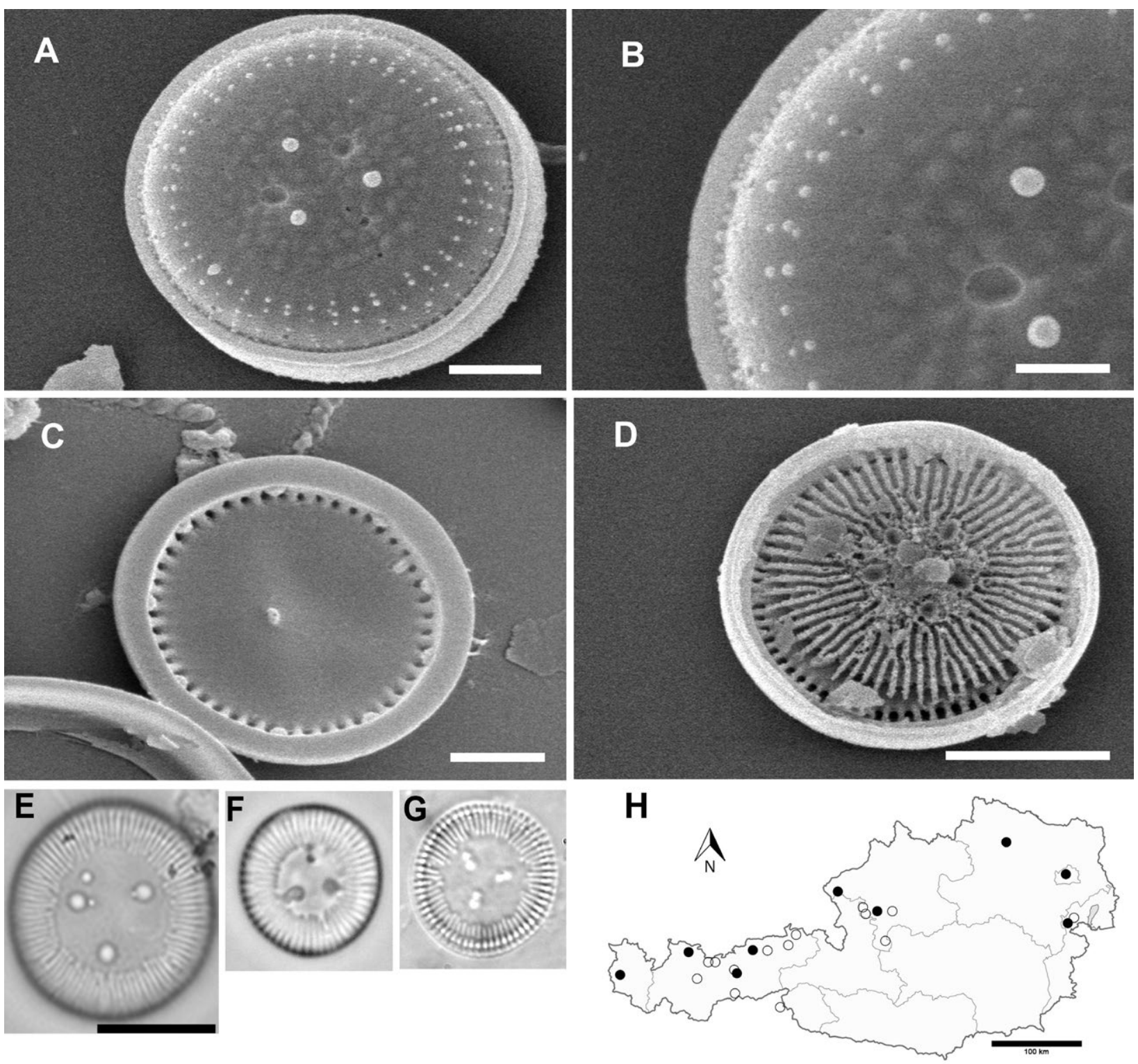

Figure 22. Pantocsekiella ocellata s.lat. A-D - scanning electron microscope images of intact (A-C) and a corroded valve (D); (A-B: showing exterior of valve with ornamentation with central granula and grooves; C: interior view with one central fultoportula with two satellite pores and a somewhat undulated valve flat, one lateral rimoportula linked to a costa and lateral ring of fultoportulae on every $5^{\text {th }}$ to $6^{\text {th }}$ costa; D: fragment of frustule shows radial branching of structures and regular arrangement of lateral alveolar structures); $\mathrm{E}-\mathrm{G}$ - light microscope images in variable focus; $\mathrm{H}$ - dispersed sampling records (black points). Scales: $\mathrm{A}, \mathrm{C}=2 \mu \mathrm{m} ; \mathrm{B}=1 \mu \mathrm{m} ; \mathrm{D}=5 \mu \mathrm{m} ; \mathrm{E}-\mathrm{G}=10 \mu \mathrm{m}$. 

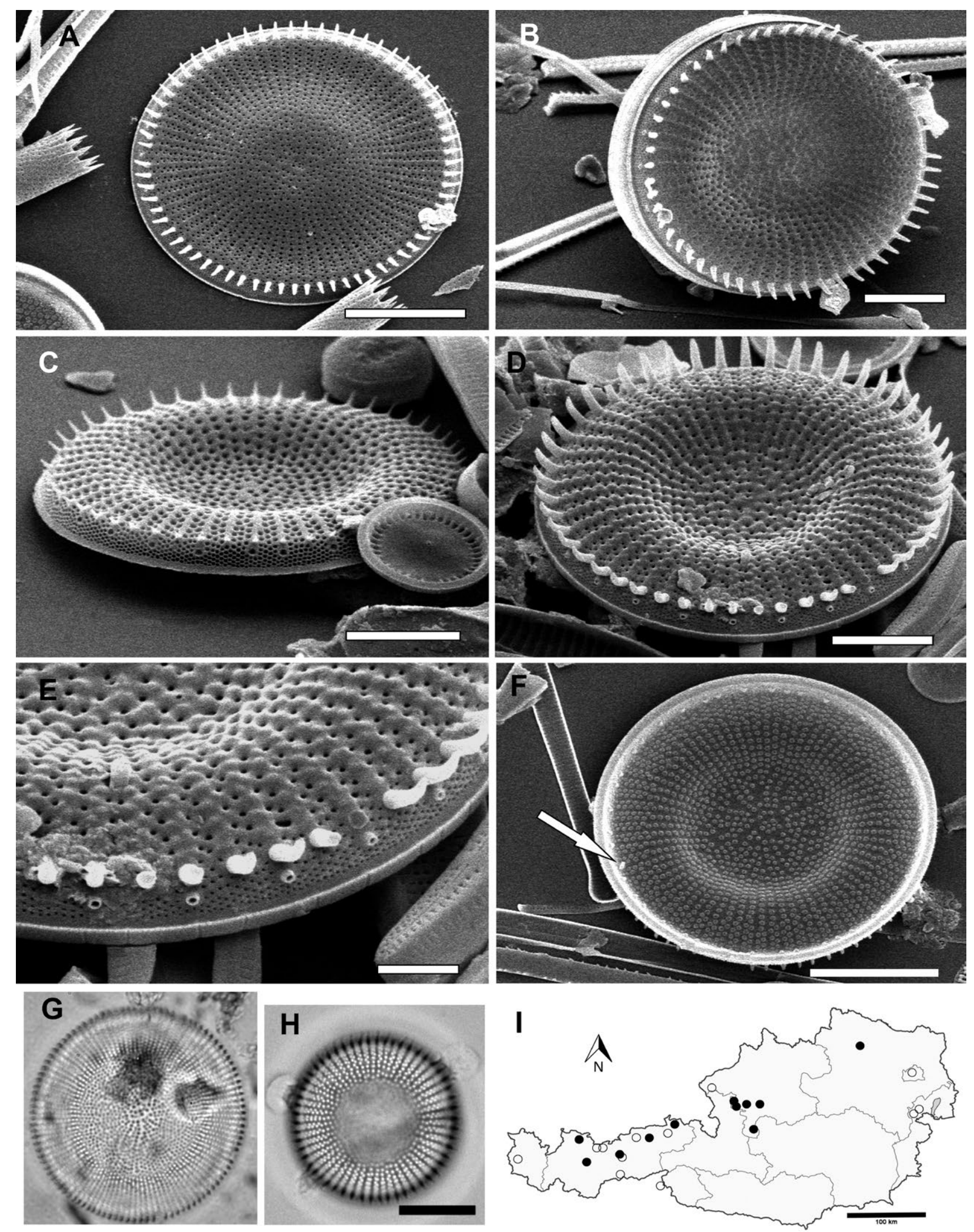

Figure 23. Stephanodiscus alpinus. A-F - scanning electron microscope images (A-E: external views with very regular radial striation reduced from two (rarely three as in C) rows of puncta at the margin to one row in the centre; lateral margin ornamented by regular ring of spines on every costa; on every second costa (rarely on neighbour ones) there is one marginal fultoportula (see C-E); arrow in interior view F: one rimoportula is completing the ring of lateral processes reaching through a hollow spine); $\mathrm{G}-\mathrm{H}-$ light microscope images with very regular aspects); I - dispersed sampling records (black points). Scales: $\mathrm{A}-\mathrm{B}=10 \mu \mathrm{m} ; \mathrm{C}-\mathrm{D}, \mathrm{F}=5 \mu \mathrm{m} ; \mathrm{E}=2 \mu \mathrm{m} ; \mathrm{G}-\mathrm{I}=10 \mu \mathrm{m}$. 
a somewhat variable concentric swelling of the epivalve (Fig. 23A) and related depression on the hypovalve (Fig. 23B-D, F). Very regular radial striation (fascicles of areolae in double or rarely in triple rows) (Fig. 23C) near the margin reduced to single points in the center of the valve. Costae with one spine each, also visible in the LM (Fig. 23G-I). Striae ending into a denser network of smaller areolae covering the mantle toward the margin of the valve (Fig. 23C, E). There is one marginal fultoportula with three satellite pores internally situated normally below every $2^{\text {nd }}$ interfascicle (costa) (Fig. 23E) with a short tubular external ending and one or two (rarely more) small single valve face fultoportulae in the center of the valve with two satellite pores. In addition, there is one small lateral rimoportula with broad lips near the margin (Fig. 23F, arrow) ending outside into a spine-like tube.
Notes. Typical taxon of the larger to middle-sized oligotrophic lakes, but also found in mesotrophic lakes (wide scatter in Fig. 23H). Delimitations of the smaller specimens of $S$. alpinus and $S$. roundii is difficult, but can be based on the more irregular arrangement and larger size of areolae in the valve center in $S$. roundii in contrast to the larger $S$. alpinus.

\section{Stephanodiscus binatus Håkansson \& Kling 1990}

(Fig. 24A-F)

Description. One of the small and delicate Stephanodiscus species related to $S$. minutulus and $S$. parvus which are supposed to be fossils as based on orginal samples (Houk et al. 2014) and which however were described from Austria earlier. A very small cylindrical taxon with circular outline (diameter 4-6(9) $\mu \mathrm{m}$ ) and with a flat valve face or somewhat concentrically domed central area on
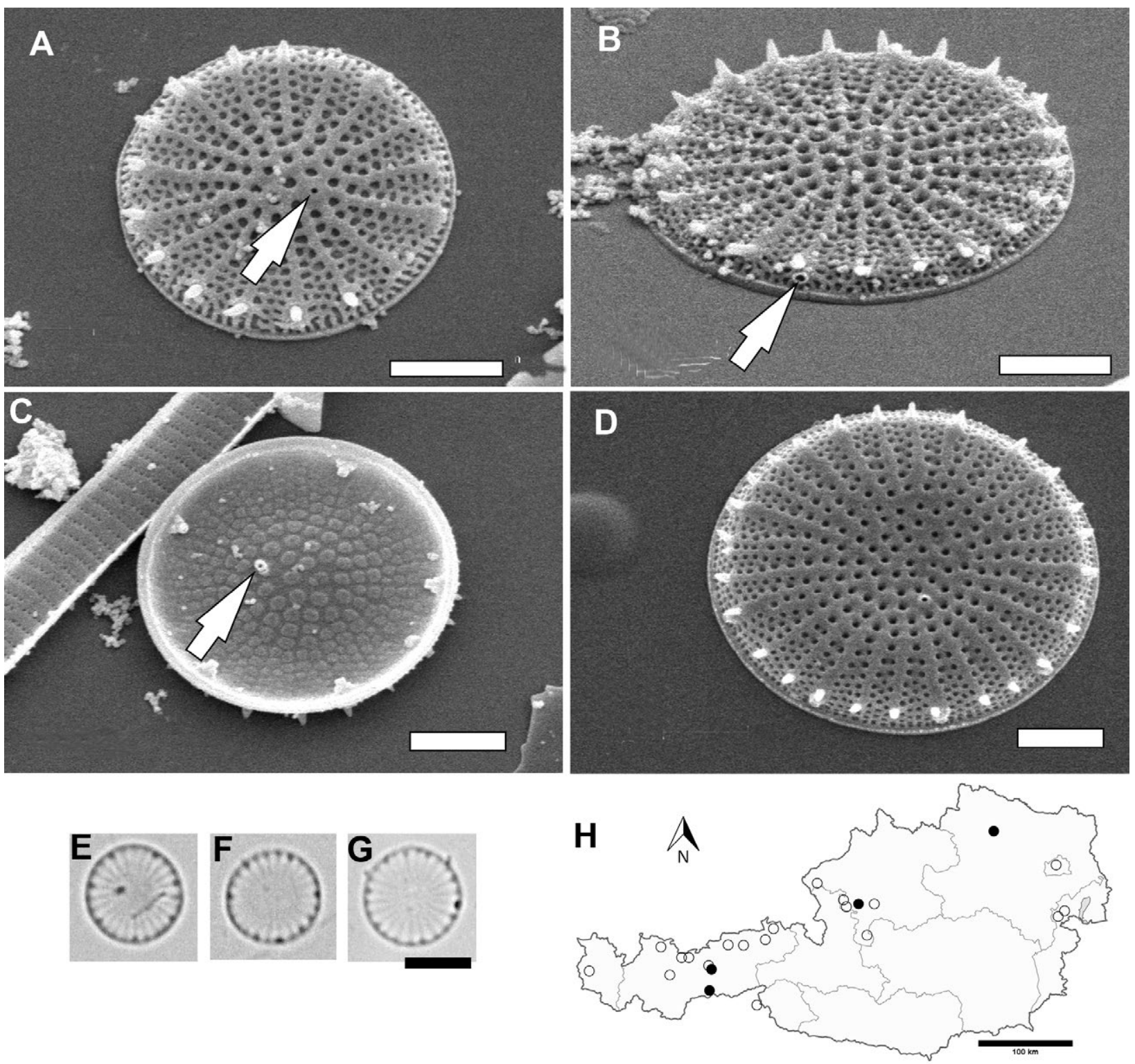

Figure 24. Stephanodiscus binatus. A-D - scanning electron microscope images (A-B: external views with very flat valve faces and a striking star-like grid of costae and lateral widening striation with up to three rows of puncta; costae with small spines and marginal fultoportulae on every third to fifth costa; C: interior with one minute marginal rimoportula and one central fultoportula with two satellite pores (arrow); D: depressed valve); $\mathrm{E}-\mathrm{G}$ - light microscope images hard to differentiate except by position of marginal fultoportulae; $\mathrm{H}$ - dispersed sampling records (black points). Scales: $\mathrm{A}-\mathrm{D}=2 \mu \mathrm{m} ; \mathrm{E}=5 \mu \mathrm{m}$. 
the epivalve (Fig. 24A) and depressed central area on the hypovalve (Fig. 24C). The marginally very broad fascicles of areolae (irregular triples or more on the margin reduced wedge-like toward the valve center) are linked to larger somewhat irregular points in the valve center. One central fultoportula with two satellite pores seen as small short tubular openings from the outside (arrow in Fig. 24A) is also seen sometimes in LM (Fig. 24E). Regular marginal spines on every costa/interstria and external short tubular opening of marginal fultoportulae with short tubular opening below every $3^{\text {rd }}$ to $5^{\text {th }}$ costa (interfascicular rib) below the spine. Striae with distant isolated areolae in the center $(25 / 10 \mu \mathrm{m})$ and fascicles with triple (quadruple) rows of puncta on the margin (40 areolae/10 $\mu \mathrm{m})$.
Notes. This taxon has been recorded from Austria and Canada only until now. Found here under variable conditions (Table S1) and potentially overlooked by its small size (Fig. 24F).

\section{Stephanodiscus hantzschii Grunow in Cleve \& Grunow 1880 \\ (Fig. 25A-B)}

Description. Frustules cylindrical 6-9(15) $\mu \mathrm{m}$ with flat valve face without any central fultoportula, only lightly silicified with rows of slit-like opening areolae outside instead of pores on valve flat (Fig. 25A-B). Striation hardly visible in the LM, but SEM shows roughly radial arranged bundles of areolae. Every interstria ornamented
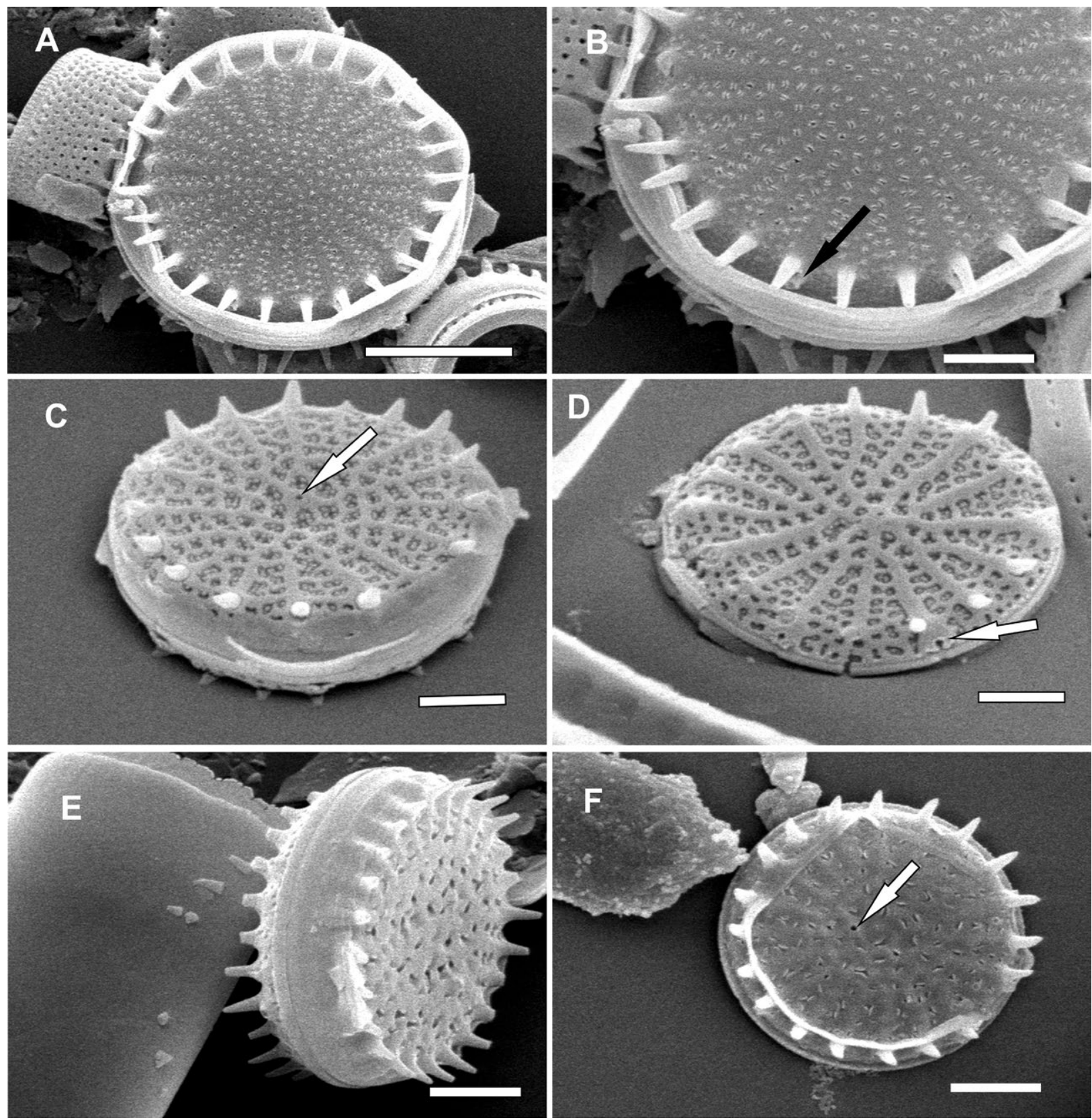

Figure 25. Stephanodiscus 3 spp. A-F - scanning electron microscope images (A-B: minute frustules related to S. hantzschii with slit-like areolae arranged in clear radial rows; arrow in B: external opening of marginal rimoportula; C-D: taxon related to S. lacustris irregular net-like arrangement of costae and irregular arranged sectors of polygonal areolae with cribrum; arrow in C: opening of one central fultoportula; E-F: S. rugosus with very irregular arranged areolae and one central fultoportula opening (arrow in F)); Scales: A $=5 \mu \mathrm{m} ; \mathrm{B}=2 \mu \mathrm{m} ; \mathrm{C}-\mathrm{F}=1 \mu \mathrm{m}$. 
by spines and every $3^{\text {rd }}$ spine on the mantle ornamented with short tubular opening of marginal fultoportulae (arrow Fig. 25B).

Notes. Occasionally found in two small eutrophic lakes, one large mesotrophic lake and one reservoir. This taxon is classified as eutraphentic in literature (Wolfram et al. 2014) as observed here (Table S2).
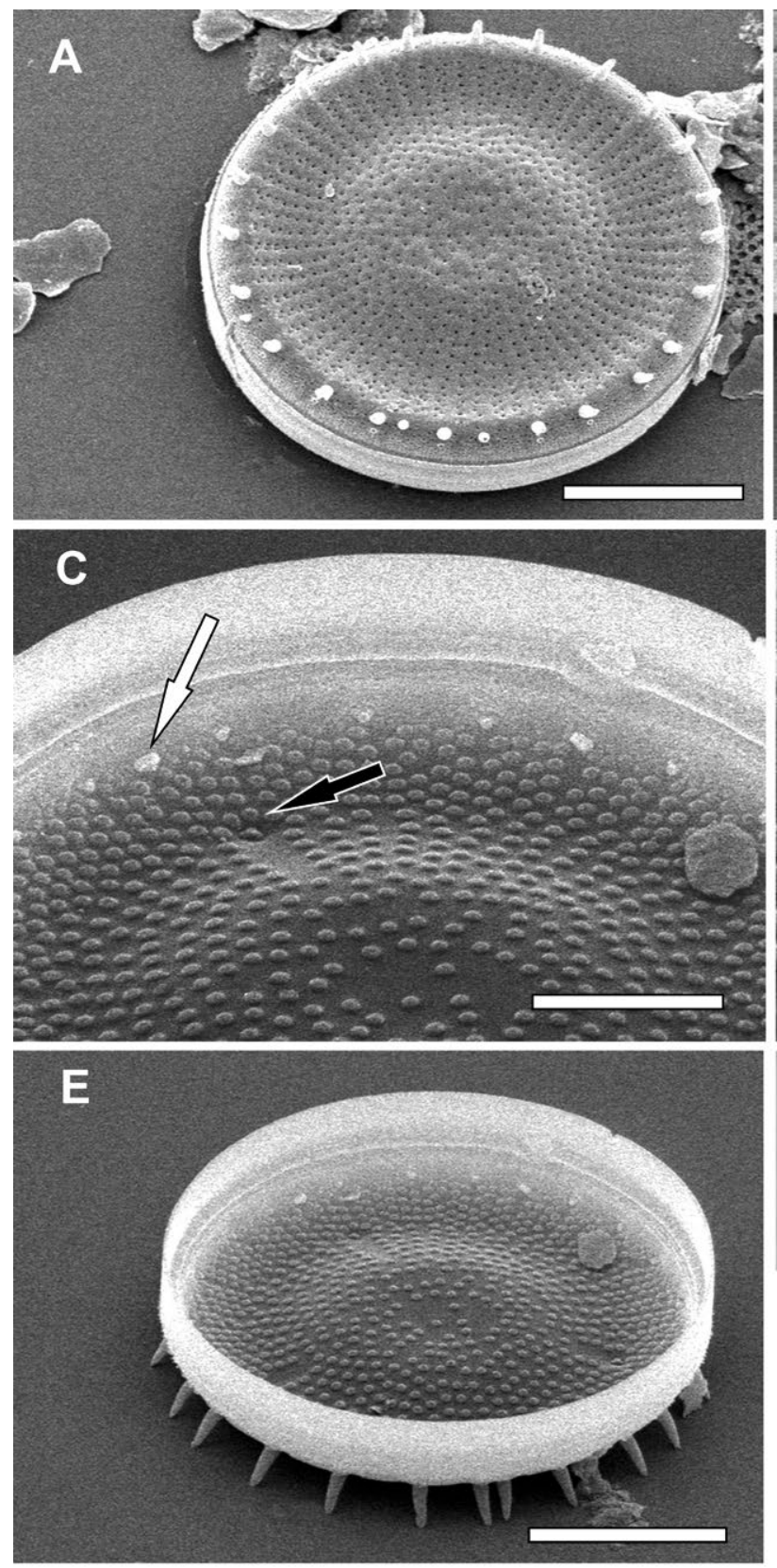

Stephanodiscus lacustris Klee \& Houk 2014

(Fig. 25C-D)

Description. Frustules cylindrical circular in outline very small $(3-4 \mu \mathrm{m})$. Central area flat with a network of interstriae each with a spine toward valve margin. Occluded areolae with foramina with rotae (Houk et al. 2014) and one central fultoportula (Fig. 25C arrow) (difference to S. hantzschii). Additionally, marginal fultoportulae under the marginal spines with porch-like opening (Fig. 25D).
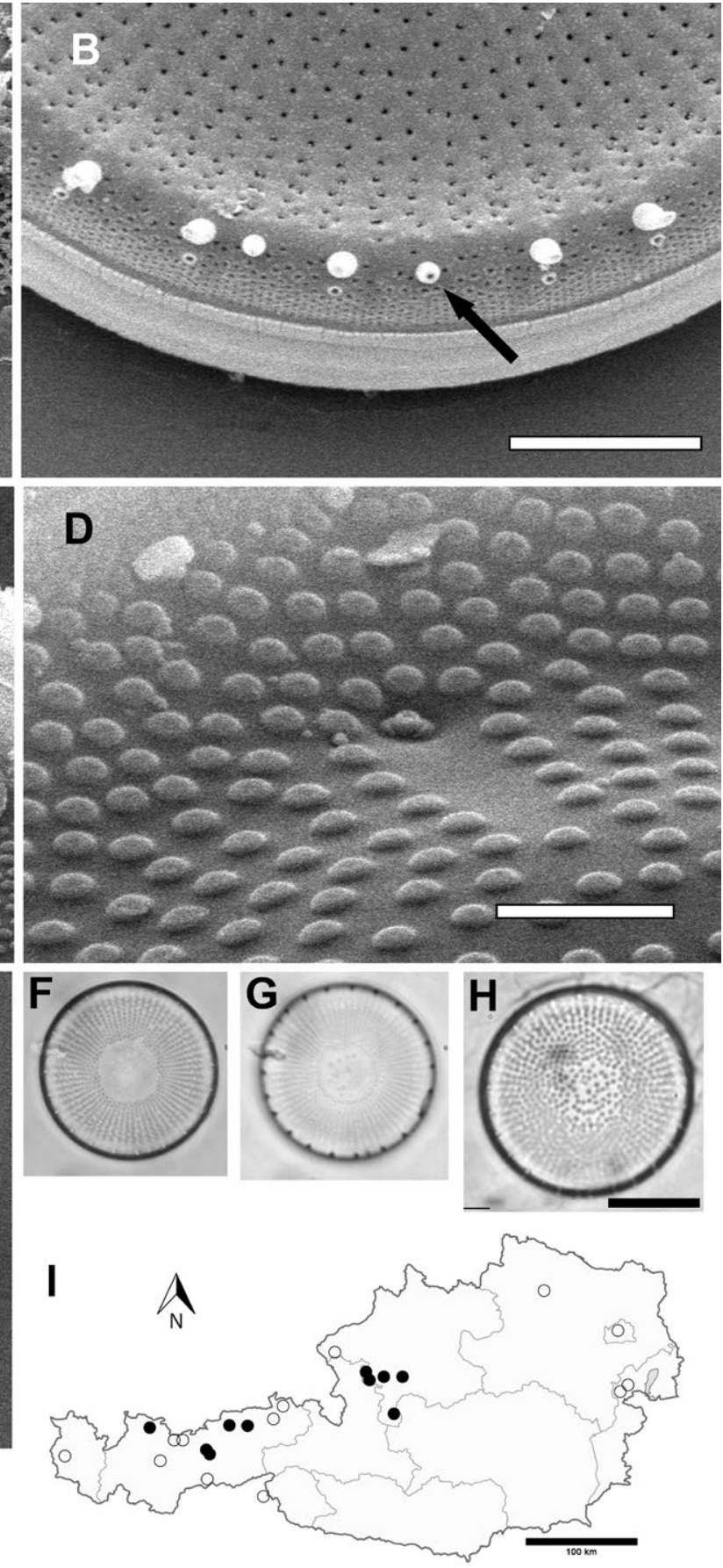

Figure 26. Stephanodiscus neoastraea. A-E - scanning electron microscope images (A-B: external overview and detail of frustule, central inflation of valve and irregular positioning of marginal spines; the striation is somewhat irregular with a variable number of points (1-2) at different distance between the costae some of which are ornamented by spines, of which the majority is related to marginal fultoportulae openings (C, internal view).; black arrow in $\mathrm{B}$, and white arrow in $\mathrm{C}$ : hollow spine what is the external opening of the single rimoportula on the valve margin; black arrow in C, close up in D: central valve face fultoportula with two satellite pores positioned in specific structureless field depression); $\mathrm{F}-\mathrm{H}-$ light microscope images show the irregularity of the striation and the positions of the marginal spines; I - dispersed sampling records (black points). Scales: $\mathrm{A}, \mathrm{E}=10 \mu \mathrm{m} ; \mathrm{B}, \mathrm{C}=5 \mu \mathrm{m} ; \mathrm{D}=2 \mu \mathrm{m} ; \mathrm{F}-\mathrm{H}=10 \mu \mathrm{m}$. 
Notes. Presumably an oligotraphentic taxon. This taxon has been described from a clean deep mountain lake in Germany/Bavaria (Houk et al. 2014). It was found only in one of the clean large perialpine lakes here (Table S1), where it was found by Houk et al. (2014).

\section{Stephanodiscus neoastraea Håkansson \& Hickel 1986}

(Fig. 26A-I)

Description. Frustules circular in outline with cylindrical cell body and a variable concentrical swelling (epivalve, Fig. 26A) or corresponding depression (hypovalve, Fig. 26E). Diameter varies from to (15)20-55 $\mu \mathrm{m}$. The striation is based on fascicles of points $(10-12 / 10 \mu \mathrm{m})$ in somewhat irregular double rows on the valve shoulder. It is becoming somewhat thinner in the marginal part of the valve face and reduced to single rows toward the center of the valve with somewhat more distant (larger) points (approx. 19/10 $\mu \mathrm{m}$ ). Interstriae less well developed, ending irregularily (every $2^{\text {nd }}-7^{\text {th }}$ ) into spines. The mantle of the valve has a much finer network of areolae than the valve flat. Lateral ring of spines mostly related to the external short tubular opening of marginal fultoportulae, with three satellite pores inside. Within this ring of spines, one rimoportula forms a hollow tubular spine externally (black arrow in Fig. 26B), internally with a broader labiate ending (detail in Fig. 26C-D). In the depression of the valve flat $0-4$ fultoportulae are situated (Fig. 26C, black arrow).

Notes. This taxon was found to be more common in meso- to eutrophic lakes than in oligotrophic lakes in the center of the observation area (Fig. 26I). Its structure (costae and density of marginal spines) is highly variable and therefore distinctly different from S. alpinus.
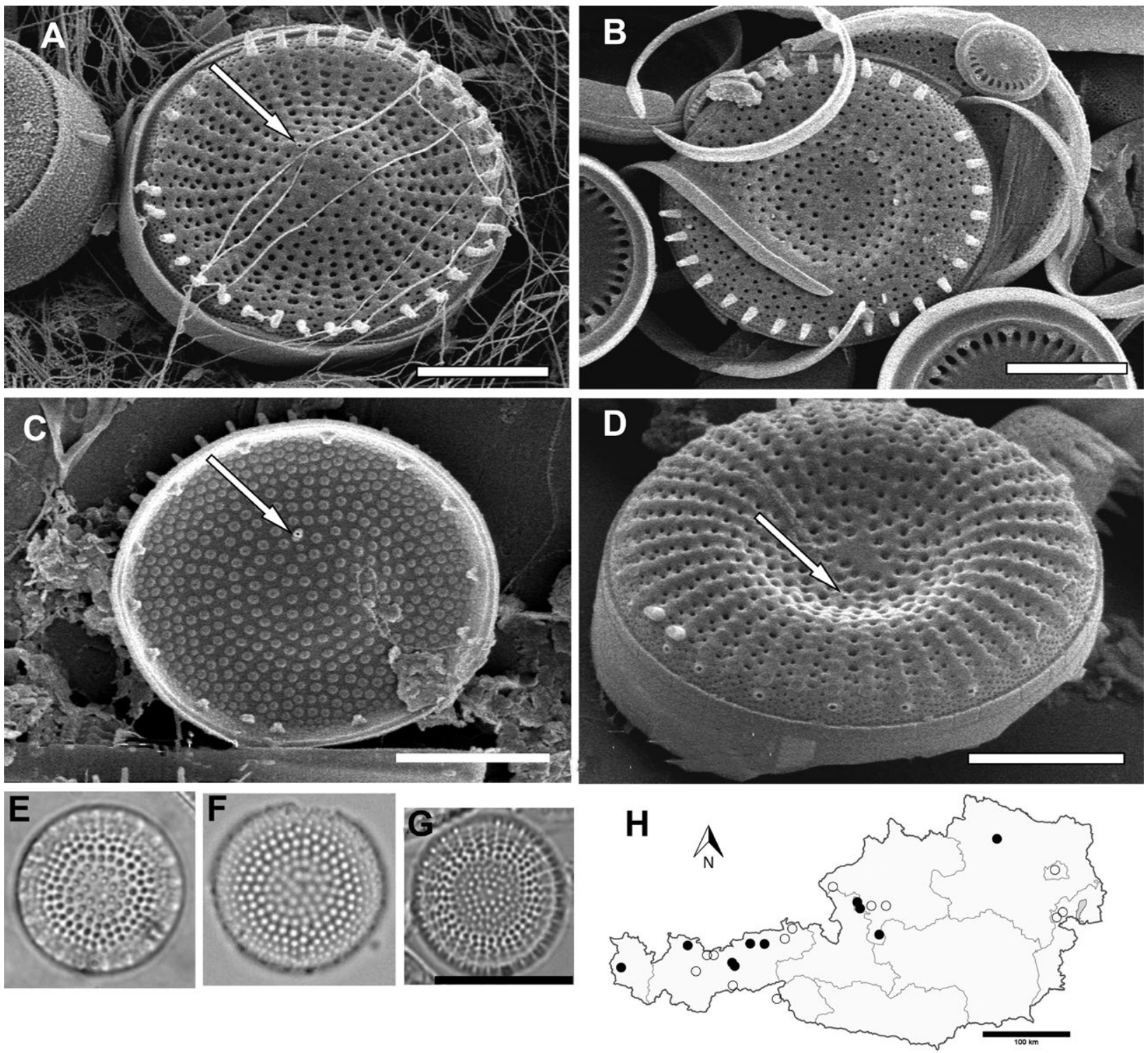

Figure 27. Stephanodiscus roundii. A-D - scanning electron microscope images (show the typical concentric waving of the frustules with radial arranged points/areolae on the margin becoming more isolated and larger in the valve centre; the marginal spines on the costae are normally dense (every second costa or more), but broken here in D; in C: ring of marginal fultoportulae; arrows in A, C-D: one central fultoportula with two satellite pores); $\mathrm{E}-\mathrm{G}$ - light microscope images show somewhat larger points in the valve centre; $\mathrm{H}$ - dispersed sampling records (black points). Scales: $A-D=5 \mu \mathrm{m} ; \mathrm{E}-\mathrm{G}=10 \mu \mathrm{m}$. 
Stephanodiscus roundii Klee \& Houk 2014

(Fig. 27A-H)

Description. Middle to small-sized taxon with circular cylindrical frustules $(6-15 \mu \mathrm{m})$. Valve face with a small central swelling on the epivalve (Fig. 27A) and a corresponding depression on the hypovalve (Fig. 27B-D). The striation of the valve flat starts shortly in double rows on the margins, somewhat irregular and changes more or less irregular into lines of single and somewhat larger areolae toward the valve center (Fig. 27D, also seen in LM Figs. 27E-G). There is one or more central fultoportula with two satellite pores in the valve center (Fig. 27A, C-D arrows). The marginal ring of fultoportulae with three satellite pores can be at regular or somewhat irregular distances with each, or every $2^{\text {nd }}$ to $4^{\text {th }}$ marginal costa. There is one small rimoportula with sessile labium close to the margin.
Notes. Widely distributed, especially in perialpine lakes (Fig. 26H), and presumably a cosmopolitan species with a broad range of occurrences. It differs from S. alpinus by coarser and more irregular structures.

Stephanodiscus rugosus Sieminska \& Chudybova 1979

(Fig. 25E-F)

Description. Small cylindrical taxon $(4-6 \mu \mathrm{m})$ with one central fultoportula (differs to $S$. hantzschii) and regular lateral spines $(15 / 10 \mu \mathrm{m})$ with rift-like outer areolae closed by irregular longitudinal slits (differences to $S$. hantzschii) instead of circular opened pores.

Notes. Found here in a small eutrophic lake and in a large mesotrophic lake. Presumably typical for meso- to eutrophic situations.
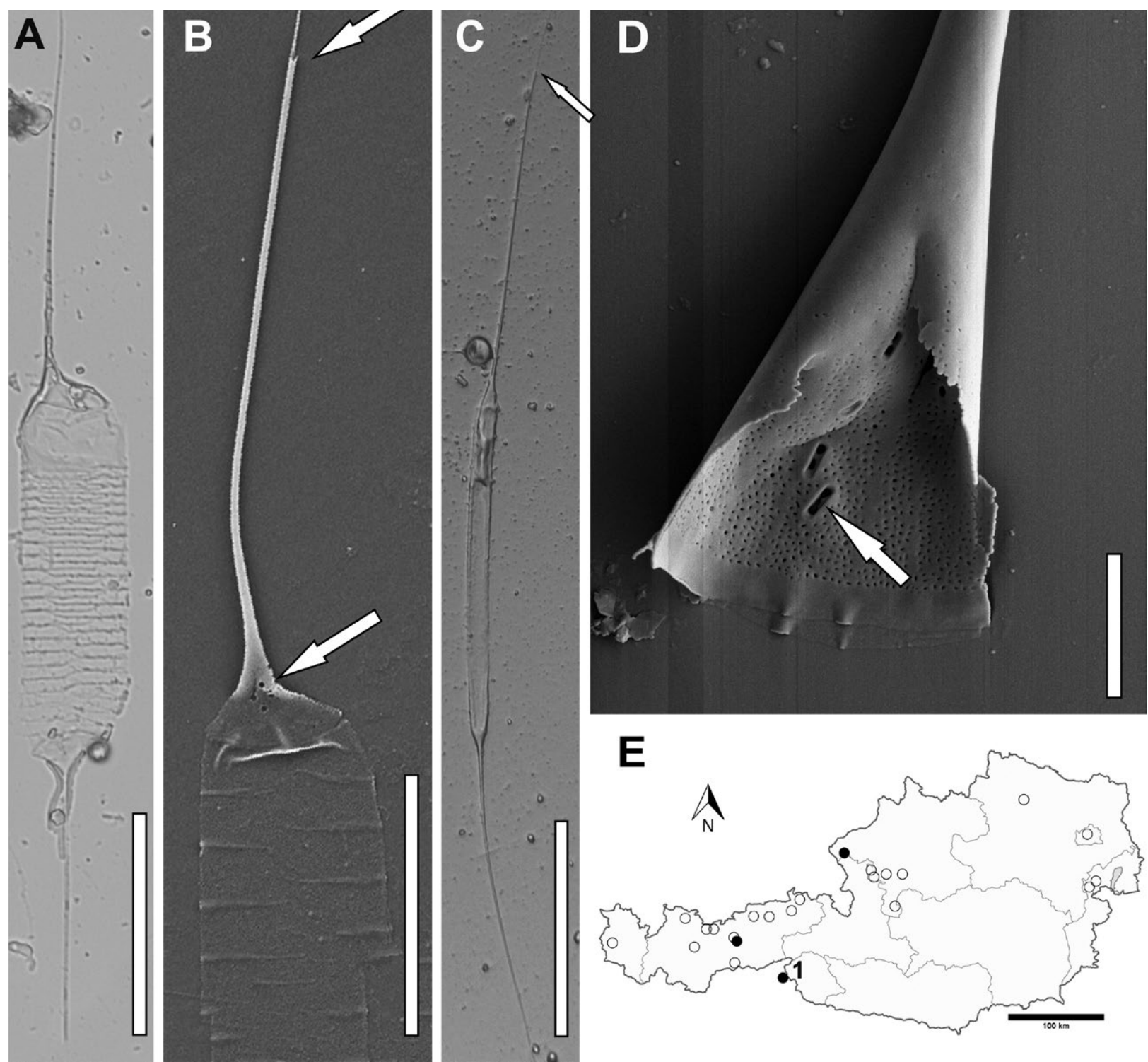

Figure 28. Urosolenia $2 \mathrm{spp}$. A, C - dry mount light microscope images, and B, D - scanning electron microscope images, (A-B: Urosolenia sp. 1 (aff. eriensis) showing calyptra with a lateral spine-like extension, ending into a short and attenuated ligula; poroids on calyptra basis round (B: arrow), spine curved; C-D; Urosolenia sp. 2 (aff. gracilis) shows very delicate frustules with slim and long cell body and a bipartite spine-like extension with a long hair-like terminal seta extending over the arrow; D - lower part of calyptra (valve) with typical button-hole-like poroids on the valve face); $\mathrm{E}$ - sampling locations for both taxa together (upper two points) and the lowermost point, where only species 1 recorded. Scales: $\mathrm{A}=15 \mu \mathrm{m} ; \mathrm{B}=10 \mu \mathrm{m} ; \mathrm{C}=25 \mu \mathrm{m} ; \mathrm{D}=2 \mu \mathrm{m}$. 


\section{Urosolenia sp. 1.}

(Fig. 28A-B)

Description. Delicate, thin silicified frustules (total length 100-180 $\mu \mathrm{m}$, cell body length $40-140 \mu \mathrm{m}$, width 5-12(15) $\mu \mathrm{m}$, spine length (10)20-40 $\mu \mathrm{m}$, copulae density 6-10(14)/10 $\mu \mathrm{m}$ ) with an extended girdle composed of multiple half rings of girdle bands or girdle scales (A.M. Schmid, pers. comm.) and two calyptra-type valves (helmet-like structures) extended into a tubular and terminal closed spine, ornamented with minute teeth and one ligula (for terminology see Rott et al. 2006). By the extension of the girdle and additional lateral depression of the subcircular to elliptic valve cross-section the frustules are normally seen in girdle view. In this species, the spines are normally inserted laterally (not subcentrally) and somewhat inclinated toward the major axis (Fig. 28A-B). This forms already during early stages of cell division an asymmetrical shape of the calyptra. In addition, the poroids on the calyptra have more depressed elliptical to circular shape, and the spine-like tubular part of the extension is shorter than in taxon 2 . The number of teeth on the ending of the tubular part is $2-4$ and the ligula (thin non-tubular spine ending) is normally short and well developed so that it is mostly discernible in LM (arrow in Fig. 28B) although very small. In general, copulae density is higher than in Urosolenia sp. 2 and the overall shape more depressed (Fig. 28A). In SEM, poroids on the calyptra flat are most frequently circular (Fig. 28B).

Notes. Like all Urosolenia-species, this taxon tends to be overlooked by its thin silicification, therefore ecological preferences unclear.

Although the description of the genus Ursolenia and the transfer of freshwater Rhizosolenia species into this taxon by Round, Crawford and Mann (1990) are highly valuable, the holotypification of Urosolenia eriensis in this publication is insufficient, since the reference figures show at least two infrageneric entities. At this point, we are unclear what $U$. eriensis looks like, thus we did not attribute a species name on this taxon yet. It seems as if this genus requires a future re-typification.

\section{Urosolenia sp. 2}

(Fig. 28C-D)

Description. Very delicate, slightly silicified frustules (total length 120-280 (400) $\mu \mathrm{m}$, cell body 70-100 $\mu \mathrm{m}$, width 4-8 $\mu \mathrm{m}$, spine length $60-140 \mu \mathrm{m}$, copulae density $1.5-2.2 / 10 \mu \mathrm{m}$ ) with conus or helmet-like calyptra (valves, Fig. 28C), only little depressed in transversal axis, extended into a long spine-like tubular structure, which ends into a very delicate and normally extremely long seta, a hair-like thin silicified structure (Rott et al. 2006). The seta is normally the uppermost third of the extension on top of the tubular calyptra part (visible in LM Fig. 28C) where 2-5 teeth in the SEM mark the end of the more massive tubular structure (also seen in LM arrow in Fig. 28C). The calyptra harbors a variable number of button-hole like (elliptic elongated) poroids (see Fig. 28D arrow).

\section{Relative abundance and determining variables}

The frequency analysis of species presence in the dataset (Fig. 29) showed a comparable low number of high frequency infrageneric taxa (five in $>50 \%$ of samples: Pantocsekiella comensis s.lat., Cyclotella distinguenda, Lindavia radiosa, Pantocsekiella costei, Stephanodiscus roundii), a considerable number (12) of mid frequency (20-40\%) taxa and a high number of low frequency taxa (15). The high frequency taxa comprise exclusively mesotraphentic species (Table S2), whereas in the medium frequency group two oligotraphentic taxa (Lindavia bodanica and Pantocsekiella kuetzingiana) and two eutraphentic taxa (Cyclotella meneghiniana, Pantocsekiella ocellata) were represented. A larger number of oligotraphentic taxa (6) and eutraphentic taxa (8) were found in the group of the lowest frequency taxa. The comparison of the ranked species of the indicator lists by Wolfram et al. (2014) with this study (under assumption of taxonomic adjustments) shows two species per ranking group identically ranked along the eutrophication axis.

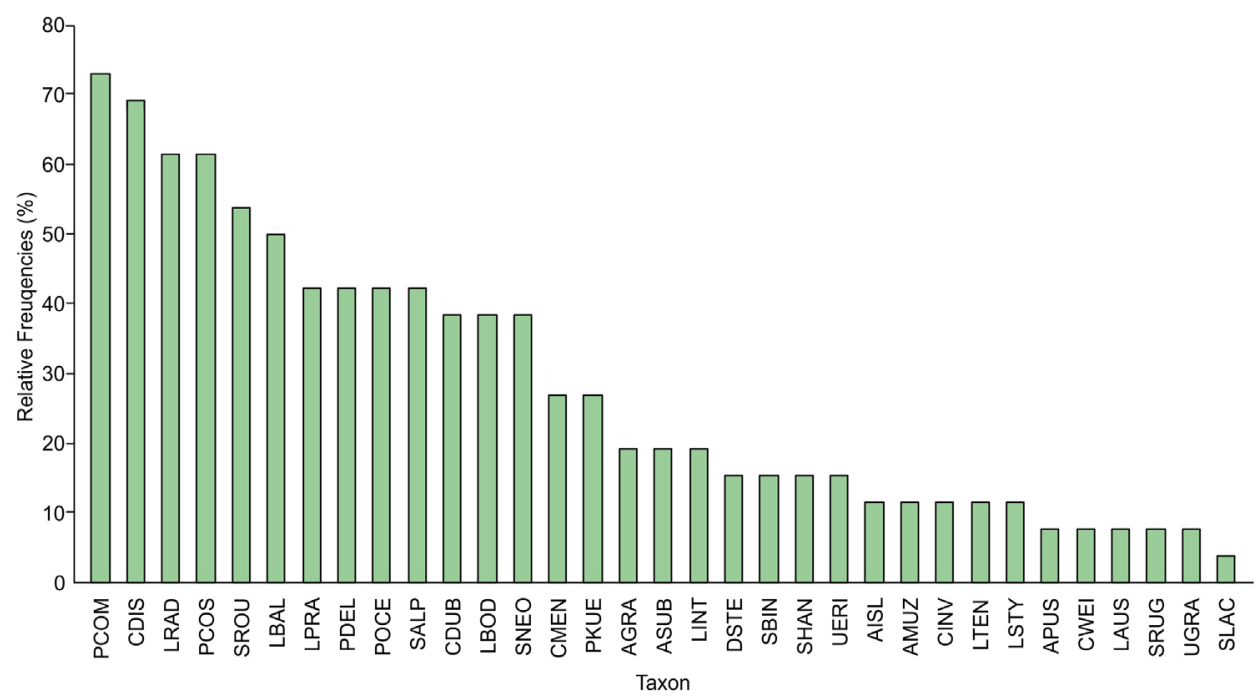

Figure 29. Frequencies of the occurrence of the 33 centric diatom taxa recorded in Austrian lakes (percentage of 54 samples from 26 sites). For list of abbreviations see Table S1. 


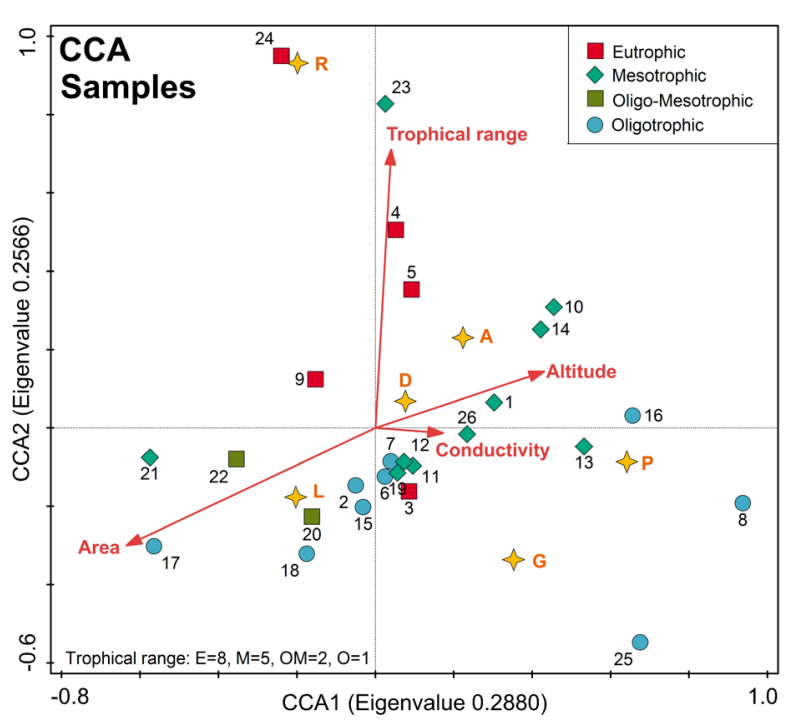

Figure 30. Constrained ordination based on CCA (Canonical correspondence analysis) of centric diatom relevées (samples) to major environmental conditions, (i.e. altitude, lake size and type, trophic status and conductivity) and lake types (abbreviations: $\mathrm{A}=$ small artificial, $\mathrm{D}=$ small deep, $\mathrm{G}=$ gravel, $\mathrm{L}=$ large deep, $\mathrm{P}=$ pond, $\mathrm{R}=$ riverine lakes; for explanation of lake key numbers see Table S1). Trophic status classes indicated by different symbols and colours.

For the grouping of the findings of centric diatoms samples, as shown in Fig. 30, the two most important regulating variables found were lake size and trophic status, whereas altitude and conductivity play a minor role. According to Monte Carlo-Permutation Test lake size explains $7.8 \%$ of the variability (simple effects; $\mathrm{P}=0.0280$ ) and trophic status explains $7.3 \%$ (simple effects; $\mathrm{P}=0.0130$ ). The position of the oligotrophic sites is scattered over the lower sectors of the graph, corresponding to the lowest trophic range. These sites, however, are mixed with mesotrophic sites. Within eutrophic sites, most are arranged along the trophic range axis in the upper sectors with two exceptions, lake 3 (a gravel lake) and lake 19 (pit lake), with both showing a wider

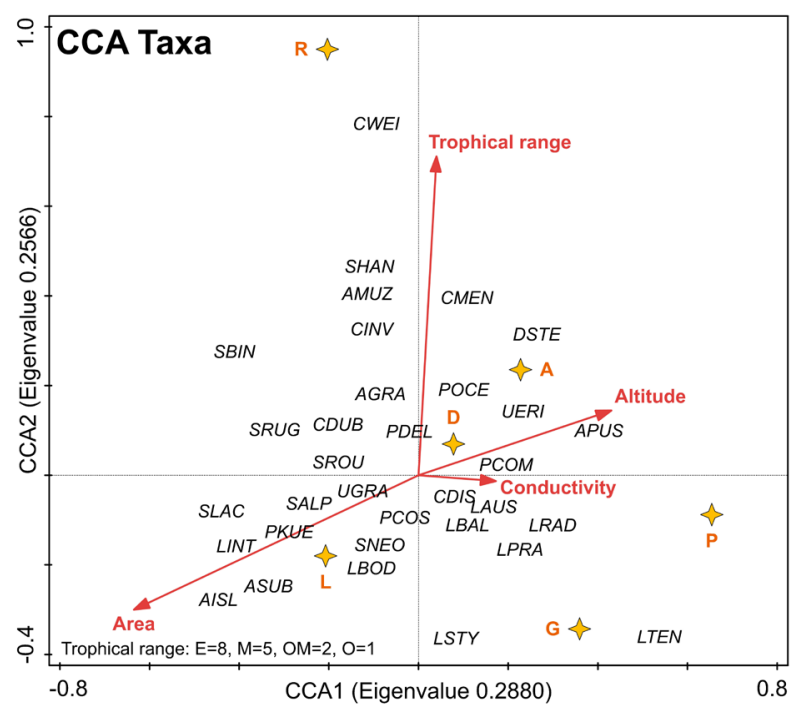

Figure 31. Constrained ordination based on CCA (Canonical correspondence analysis) of centric diatom species (presence) and regulating environmental variables (same as in Fig. 30). For species abbreviations see Table S1. variety of taxa with some exceptional oligotraphentic elements.

The positioning of the individual centric diatom taxa in relation to site and environmental data in Fig. 31 shown corresponds to a large extent to the trophical ranking of taxa as described above. Some oligotrophentic taxa (e.g., LBOD, LSTY, LTEN ) are positioned in the lower extreme of the trophic range down in the center, whereas eutrophentic taxa (e.g., CWEI, AMUZ, SHA, CINV, AMUZ) are grouped at the upper extreme of the trophic gradient. Other taxa, although oligotraphentic, are related to the lake size gradient and, in fact, are occurring preferentially (PKUE) or even exclusively (LINT) in the largest lakes. The altitude scale is inversely related to lake size, i.e. the majority of the largest lakes studied are situated at lower altitudes and many smaller lakes at higher altitudes.

\section{Discussion}

This taxonomic, morphology and ultrastructure based investigation of 26 water bodies of the Eastern Alps showed an interesting diversity of centric diatoms, altogether more than 30 species from nine genera, although the sampling scheme was somewhat biased by more frequent sampling in the W (see contour maps in Figs 1-24 white (no occurrences) and black circles (occurrences). It covers a broader gradient of sites in relation to trophic status and species richness. One exceptional small and enriched site was most rich in centric species (19) (see Table S1). Almost all large lakes, especially in the perialpine zone, had $>10$ taxa with a few taxa specific to those environments due to long-term persistence of taxa in oligotrophic situations. Lindavia intermedia, typical for subarctic large lakes (Daniels et al. 2016), however, is known from many perialpine large lakes especially in the $\mathrm{N}$ of the Alps (Houk et al. 2010).

How do our findings relate to comparable regional studies of centric diatoms? Although a broader study from Hungarian rivers initially seems unlikely to be comparable, but it showed some higher richness ( $>40$ taxa) and an unexpected high portion of shared taxa (almost 50\% of taxa) when taxonomic changes were taken into consideration. However although Cyclotella meneghiniana, a presumably eutraphentic taxon, was the most frequent (i.e., found in $>60 \%$ of river samples) in Hungary (Kiss et al. 2014), it was only a medium frequent taxon in the Eastern Alpine lakes. Two Cyclostephanos species (C. dubius and C. invisitatus) were among the most frequent in Hungary but only showed medium and rare frequency, respectively, in the Eastern Alps. The study of small waterbodies from Poland uplands (Wojtal \& Kwandrans 2006) showed a dominance of eutrophic situations with different dominant taxa (Cyclotella meneghiniana, Cyclotella atomus, Stephanodiscus hantzschii), but 11 of 20 taxa were shared within the two study regions. Especially minute centrics (Cyclotella atomus; Thallasiosira- and Skeletonema species) present in the studies from Hungary and Poland are missing in this study of the Eastern Alpine lakes. One of the most eutraphentic taxa (see Fig. 31) shared with Hungary is Conticribra 
weissflogii. This species is unusual in alpine lakes, but was recorded in one subalpine lake and a riverine lake, both with a strong influence by road salts. The comparison of the results from the Eastern Alps with an extended study of lakes and rivers in Anatolia (Turkey) (Solak et al. 2018) showed again approximately $50 \%$ shared centric taxa, but one presumably regional restricted taxon (Pantocsekiella iranica). Taxa typical of the Eastern Alps are chain-forming taxa from the largest lakes mostly in Upper Austria (Aulacoseira islandica, A. subarctica), taxa related to larger lakes in general (Lindavia bodanica) and/or, taxa originally described from oligotrophic lakes, but rarely found in Austria (e.g., Pantocsekiella austriaca, P. tenuistriata and P. styriaca in Wunsam et al. 1995; Houk et al. 2014). Additional taxa overlooked here when the Eastern Alps centric diatoms are considered, are those recorded from high mountain lakes, especially several Aulacosira species (e.g., A. alpigena, A. lirata, A. nivalis A. nygardii, A. perglabra in Koinig 1998, 1999 and A. valida, Koinig pers. comm. and own observation). Several of those are mentioned as highly endangered taxa in the Red List of Diatoms for Germany (Lange-Bertalot 1996).

There are several problems encountered in identification of centric diatoms, some related to seasonal and onthogenetical variability of features (Schmid 1994). Reduced cell size (by age or limiting resources) has an influence on numbers and positions of rimo- and fultoportulae (Kling H., pers. comm.), but was rarely studied (e.g., Lake Como, Scheffler \& Morabito 2003). Heterovalvarity tends to be commonly overlooked (Teubner 1995) although it is a common feature and frequent in some infrageneric taxa as shown here ( $P$. delicatula in Fig. 20D). Molecular marker genes have often contributed significantly to formalize morphological and ultrastructural templates. The molecular approach was very successful in the case of re-structuring large and divergent genera (e.g., Cyclotella s.lat., Lindavia and Pantoscekiella well recognizable even in LM). However, the infrageneric differentiaton of Pantoscekiella, especially of the species groups around P. comensis, P. pseudocomensis and P. costei (e.g., higher phenotypic plasticity than molecular differentiation (Kistenich et al. 1994)) was not found, although within the same genus, molecular differences between the P. ocellata - (for variability see Cvetkovska et al. 2014) and P. comensis-species groups could be confirmend by Duleba et al. (2015). At this point, this is why we applied a wider preliminary taxon classification for P. comensis s.lat., P. ocellata s.lat. and Discostella stelligera s.lat.

When taxonomic identities are preliminarily considered, the comparison of taxa lists arranged from oligotrophic to eutrophic (Table S2) resulted into several identical ranks with the valid indicator lists for Austria (Wolfram et al. 2014). The statistical analyses showed that diatom samples (associations) and individual taxa are primarily regulated by lake size and trophic status (Figs 29,30 ), although a more general classification model for trophic status was applied. The fact that all most frequent taxa were classified as mesotrophic is likely to be an effect of limited samples or little divergence of the trophic status of sampling sites. In addition, true geographic differentiaton of centric taxa over larger scales (reservoirs all over Spain, Aulacoseira islandica vs A. granulata) and distribution patterns related to geology based water hardness can occur (Sabater 1991). Eutrophication leading to changes of centric diatoms has been documented for Lake Mondsee (Austria) where Aulacoseira subarctica replaced Aulacoseira islandica in dominance since the 1980s (Schmidt 1991; Dokulil 2017). In recent years, large Eastern Alpine lakes have shown a reverse trend to eutrophication. The reversion of dominant centric diatoms to oligotrophic lakes may be a slower process (see Dokulil 2017) that will allow the use of centric species composition to trace these changes in future.

Centric diatom taxonomy is also essential to detect effects of climate change on centric diatom composition and dominance. This was found useful in a long-term study of phytoplankton in the lowland reservoir Seidenbachtalsperre in Germany (Horn et al. 2011), where Aulacoseira subarctica bloomed during the warmer winters in recent years. In high mountain lakes, environmental, including climate change scenarios, already led to changes of centric diatoms as observed by Koinig et al. (1999) and Catalan et al. (2002, 2013). Nitrates may favour diatoms under climate change scenarios and nitrogen enrichment (Camargo \& Alvaro 2006). Centric diatoms were also proposed as essential elements of different functional groups of phytoplankton, not only based on size and geometric shape, but even on a species level (infrageneric) functionality as postulated by Reynolds et al. (2002), revised by Padisák et al. (2009). This concept was recently applied successfully to karst-lakes in the Balkan area (Udovic et al. 2016).

\section{Acknowledgements}

This work would not have been possible without the generous support of Prof. K. Oeggl with the SEM facilities at the Institute of Botany Innsbruck, as well as the support by sponsorships for three Central European Diatom meetings held at Innsbruck by the Rectorate of the Leopold Franzen University of Innsbruck. The activities in context with this manuscript go back to an initiative by Dr. Georg Wolfram and Mag. Romana Niedermayer, DWS-Hydro-Oekologie, Vienna stimulating centric diatom studies and expert classes in context of Central European Diatom meetings since 2008. We thank Rolf Klee, Bodenmais, Bavaria, Germany for taxonomic confirmations and Hedy Kling, Algal Inc., Winnipeg, Canada for some critical comments. We also acknowledge the careful reading, multiple useful suggestions and support to improve this MS by two anonymous reviewers.

\section{Supplementary electronic material}

Figure S1. Comparison of light microscopical and scanning electron microscopical key features for frequent large (uppermost block), medium-sized (middle) and small-sized (lowest) single-celled centric diatoms from the lakes in the Eastern Alps (note the different scale bars for light micrographs within the three size groups and the preliminary classifications within the Pantocsekiella comensis species group). Download file

Figure S2. LM of Lindavia austriaca $($ scale $=10 \mu \mathrm{m})$. Download file

Table S1. Centric diatom species recorded in 26 stagnant water bodies in the Eastern Alps and Forelands, and features of the habitats. Lake 
numerations used are the same as in Fig. 30. For abbreviations of taxa names see column 2, for full lake names and all other abbreviations see footnotes. Download file

Table S2. Taxon-specific trophical score ranking of centric diatoms from oligotraphentic (blue) to mesotraphentic (green) and eutraphentic (red) according to Wolfram et al. 2014 (Rebecca Codes and species names) and this dataset ( $3^{\text {rd }}$ column) ranked with weighting factors as in Fig. 30 (right column). Download file

\section{References}

Ács, É., Ari, E., Duleba, M., Dressler, M., Genkal, S. I., Jakó, É., Rimet, F., Ector, L. \& Kiss, K. T. 2016. Pantocsekiella, a new centric diatom genus based on morphological and genetic studies. Fottea 16: 56-78. https://doi.org/10.5507/fot.2015.028

Bahls, L. 2013. Lindavia radiosa. In: Diatoms of North America. https:// diatoms.org/species/lindavia_radiosa [accessed 12 December 2019]

Buzzi, F., G. Morabito \& A. Marchetto, 2011. L'indice fitoplanctonico PTIot per la valutazione della qualità ecologica dei laghi. Report ISE-CNR: 33-43 https://core.ac.uk/download/pdf/37834397.pdf\#page $=33$

Camargo, J. A. \& Alvaro, A. 2006. Ecological and toxicological effects of inorganic nitrogen pollution in aquatic ecosystems: A global assessment. Environment International 32: 831-849. https://doi. org/10.1016/j.envint.2006.05.002

Catalan, J., Pla, S., Rieradevall, M., Felip, M., Ventura, M., Buchaca, T., Camarero, L., A. Brancelj, A., Appleby, B. J., Lami, A., Grytnes, J. A., Agustí-Panareda, A. \& Thompson, R. 2002. Lake Redó ecosystem response to an increasing warming in the Pyrenées during the twentieth century. Journal of Paleolimnology 28: 129-145. https://doi.org/10.1023/a:1020380104031

Catalan, J., Pla-Rabe, S., Wolfe, A. P., Smol, J. P., Rühland, K. M., Anderson, N. J., Kopacek, J., Stuchlik, E., Schmidt, R., Koinig, K. A., Camarero, L., Flower, R. G. Heiri, O., Kamenik, C., Korhola, A., Laevitt, P. R., Psenner, R. \& Renberg, I. 2013. Global change revealed by palaeolimnological records from remote lakes: a review. Journal of Paleolomnology 49: 513-535. https://doi.org/10.1007/ s10933-013-9681-2

Cvetkoska, A., Hamilton, P. B., Ognjanova-Rumenova, N. \& Levkov, Z. 2014. Observations of the genus Cyclotella (Kützing) Brébisson in ancient lakes Ohrid and Prespa and a description of two new species C. paraocellata sp. nov. and C. prespanensis sp. nov. Nova Hedwigia 98: 313-340. https://doi.org/10.1127/0029-5035/2014/0154

Daniels, W. C. 2012. Lindavia intermedia. In: Diatoms of North America. Retrieved June 18, 2019, from https://diatoms.org/species/lindavia_intermedia

Daniels, W. C., Novis, P. M. \& Edlund, M. B. 2016. The valid transfer of Cyclotella bodanica var. intermedia to Lindavia (Bacillariophyceae). Notulae algarum 14: 1-3.

Dixit, S. S., Smol, J. P., Kingston, J. C. \& Charles, D. F. 1992. Diatoms: Powerful indicators of environmental change. Environmental Science and Technology 26: 23-32. https://doi.org/10.1021/ es00025a002

Dokulil, M. T. 2017. Alpenrandseen im Anthropozän: Verschlechterung und Sanierung: eine österreichische Erfolgsgeschichte. Acta ZooBot Austria 154: 1-53.

Duleba, M., Kiss, K. T., Földi, A., Kovács, J., Borojević, K. K., Molnár, L. F., Plenkovic-Moraj, A., Poner, Z., Solak, C. N., Toth, B. \& Ács, É. 2015. Morphological and genetic variability of assemblages of Cyclotella ocellata Pantocsek / C. comensis Grunow complex (Bacillariophyta, Thalassiosirales). Diatom Research 30: 283-306. https://doi.org/10.1080/0269249x.2015.1101402

English, J. \& Potapova, M. 2010. Aulacoseira granulata var. angustissima. In: Diatoms of North America. Retrieved June 22, 2019, from https://diatoms.org/species/aulacoseira_granulata_angustissima
European Union, 2000. Directive 2000/60/EC of the European Parliament and the Council of 23 October 2000 establishing a framework for Community action in the field of water policy. Official Journal of the European Communities L327: 1-72. https://doi.org/10.1017/ cbo9780511610851.056

Guiry, M. D. \& Guiry, G. M. 2020. AlgaeBase. World-wide electronic publication, National University of Ireland, Galway. http://www. algaebase.org; searched on 15 January 2020.

Håkansson, H. 1989. A light and electron microscopical investigation of the type species of Cyclotella (Bacillariophyceae) and related forms, using original material. Diatom Research 4: 255-267. https:// doi.org/10.1080/0269249x.1989.9705075

Hall, R., \& Smol, J. 1999. Diatoms as indicators of lake eutrophication. In: Stoermer, E. \& Smol, J. (eds), The Diatoms: Applications for the Environmental and Earth Sciences, pp. 128-168. Cambridge, Cambridge University Press. https://doi.org/10.1017/ cbo9780511613005.007

Horn, H., Paul, L., Horn, W. \& Petzold, T. 2011. Long-term trend in the diatom composition of the spring bloom of a German reservoir: Is Aulacoseira subarctica favoured by warm winters? Freshwater Biology 56: 2483-2499. https://doi.org/10.1111/j.13652427.2011.02674.x

Houk, V., Klee, R. \& Tanaka, H. 2010. Atlas of freshwater centric diatoms, with a brief key and descriptions. Part 3: Stephanodiscaceae A: Cyclotella, Tertiarius, Discostella. In: Poulickova, A. (ed.), Fottea 10 (Supplement): 1-498.

Houk, V., Klee, R. \& Tanaka, H. 2014. Atlas of freshwater centric diatoms, with a brief key and descriptions. Part 4: Stephanodiscaceae B. Stephanodiscus, Cyclostephanos, Pliocaenius, Hemistephanos, Stephanocostis, Mesodictyon and Spicaticribra. In: Poulickova, A. (ed.), Fottea 14 (Supplement): 1-529.

Houk, V., Klee, R. \& Tanaka, H. 2017. Atlas of freshwater centric diatoms, with a brief key and descriptions. Second emended edition of Part I and II. Melosiraceae, Orthoseiraceae, Paraliaceae and Aulacoseiraceae. In: Poulickova, A. (ed.), Fottea 17 (Supplement): $1-615$.

Hustedt, F. 1927. Die Diatomeen der interstadialen und stadialen Seekreide des Profils DC. In: Gams, H. (ed.), Die Geschichte der Lunzer Seen, Moore und Wälder. Internationale Revue der gesamten Hydrobiologie und Hydrographie 18: 317-320.

Kiss, K. T., Klee, R., Ector, L. \& Ács, É. 2012. Centric diatoms of large rivers and tributaries in Hungary: morphology and biogeographic distribution. Acta Botanica Croatica 71: 311-363. https:// doi.org/10.2478/v10184-011-0067-0

Kistenich, S., Dressler, M., Zimmermann, J., Hübener, T. \& Bastrop, R. 2014. An investigation into morphology and genetic of Cyclotella comensis and closely related taxa. Diatom Research 29: 423-440. https://doi.org/10.1080/0269249x.2014.922125

Koinig, K., Schmidt, R., Sommaruga-Wögrath, S., Tessadri, R. \& Psenner, R. 1998. Climate change as the primary cause for $\mathrm{pH}$ shift in high alpine lakes. Water, air and soil pollution 104: 167-180. https://doi.org/10.1023/a:1004941013924

Koinig, K., Schmidt, R. \& Psenner, R. 1999. Effect of air temperature changes and acid deposition on the $\mathrm{pH}$ history of three high alpine lakes. In: Maiama, S., Idei, M. \& Komuzumi, I. (eds), 14th International Diatom Symposium, pp. 467-478. Koeltz Scientific Books, Königstein.

Krammer, K. \& Lange-Bertalot, H. 1991. Bacillariophyceae 3. Teil Centrales, Fragilariaceae, Eunotiaceae. In: Ettl, H., Gerloff, J., Heynig, H. \& Mollenhauer, D. (eds), Süsswasserflora von Mitteleuropa. Gustav Fischer Verlag, Stuttgart.

Lange-Bertalot, H. 1996. Rote Liste der limnischen Kieselalgen (Bacillariophyceae) Deutschlands. Schriftenreihe für Vegetationskunde 28: 633-677.

Lotter, A. 2001. The effect of eutrophication on diatom diversity: examples from six Swiss lakes. In: Jahn, R., Kociolek, J., Witkowski, A. \& Compère, P. (eds), Lange-Bertalot Festschrift, pp. 417-432. Gantner Verlag, Rugell. 
Mischke, U., Riedmüller, U., Hoehn, E., Schönfelder, I. \& Nixdorf, B. 2008. Description of the German system for phytoplankton-base assessment of lakes for implementation of the EU Water Framework Directive (WFD). Gewässerreport 10, Aktuelle Reihe 2/2008. Bad Saarow, Freiburg, Berlin, Universität Cottbus, Lehrstuhl Gewässerschutz: $117-146$.

Nakov, T., Guillory, W., Julius, M. Theriot, E. \& Alverson, A. 2015. Towards a phylogenetic classification of species belonging to the diatom genus Cyclotella (Bacillariophyceae): Transfer of species formerly placed in Puncticulata, Handmannia, Pliocaenicus and Cyclotella to the genus Lindavia. Phytotaxa 217: 249-264. https:// doi.org/10.11646/phytotaxa.217.3.2

Oberösterreichische Landesregierung, 2018. Kurzprofile oberösterreichischer Seen. Kurze Darstellung der einzelnen oberösterreichischen Seen: ökologischer und trophischer Zustand (2014-2016), bakteriologische und chemisch-physikalische Parameter (2013-2017), Archiv 2007-2009 und 2010-2012. https://www.land-oberoesterreich.gv.at

Padisák, J., Crossetti, L. \& Naselli-Flores, L. 2009. Use and misuse in the application of the phytoplankton functional classification: a critical review with updates. Hydrobiologia 621: 1-19. https:// doi.org/10.1007/s10750-008-9645-0

Pasztaleniec, A. 2016. Phytoplankton in the ecological status assessment of European lakes - advantages and constraints. Environmental protection and natural resources 27 : 26-36. https://doi.org/10.1515/ oszn-2016-0004

Pipp, E. \& Rott, E. 1995. A phytoplankton compartment model for a small meromictic lake with special reference to species niches and long-term changes. Ecological Modelling 78: 129-148. https:// doi.org/10.1016/0304-3800(94)00123-y

Reynolds, C. S., 1984. Phytoplankton periodicity: the interactions of form, function and environmental variability. Freshwater Biology 14: 111-142. https://doi.org/10.1111/j.1365-2427.1984.tb00027.x

Reynolds, C. S., de Huszar, V. L. M., Kruk, C., Naselli-Flores, L. $\&$ Melo, S. 2002. Towards a functional classification of the freshwater phytoplankton. Journal of Plankton Research 24: 417-428. https://doi.org/10.1093/plankt/24.5.417

Rivera-Rondón, C. A. \& Catalan, J. 2017. Diatom diversity in the lakes of the Pyrenees: an iconographic reference. Limnetica 36: 127-396. https://doi.org/10.23818/limn.36.10

Rivera-Rondon, C. A. \& Catalan, J., 2019. Diatoms as indicators of the multivariate environment of mountain lakes. Science of the Total Environment 703: 135517. https://doi.org/10.1016/j.scitotenv.2019.135517

Rioual, P., Jewson, D., Liu, Q., Chu, G., Han, G. \& Liu, J. 2017. Morphology and ecology of a new centric diatom belonging to the $C y$ clotella comta (Ehrenberg) Kützing complex: Lindavia khinganensis sp. nov. from the Greater Khingan Range, Northeastern China. Cryptogamie, Algologie 38: 349-377. https://doi.org/10.7872/crya/ v38.iss4.2017.349

Rott, E. 1984. Phytoplankton as a biological parameter for the trophic characterization of lakes. Mitteilungen der Internationalen Vereinigung für Limnologie 22: 1078-1085.

Rott, E., Kling, H. \& McGregor, G. 2006. Studies on the diatom Urosolenia Round and Crawford (Rhizosoleniophycidae) Part 1. New and re-classified species from subtropical and tropical freshwaters. Diatom Research 21: 105-124. https://doi.org/10.1080/0269 249x.2006.9705655

Round, F. E., Crawford, R. M. \& Mann, D. G. 1990. The diatoms. Cambridge University Press, Cambridge, U.K.

Sabater, S. 1991. Size as a factor in centric diatom distribution: The Spanish reservoirs as an example. Oecologia aquatica 10: 45-40.

Salmaso, N., Morabito, G., Buzzi, F., Garibaldi, L., Simona, M. \& Mosello, R. 2006. Phytoplankton as an indicator of the water quality of the deep lakes south of the Alps. Hydrobiology 563: 167-187. https://doi.org/10.1007/s10750-005-0003-1

Scheffler, W. \& Morabito, G. 2003. Topical observations on centric diatoms (Bacillariophyceae, Centrales) of Lake Como (N. Italy). Journal of Limnology 62: 47-60. https://doi.org/10.4081/jlimnol.2003.47

Scheffler, W., Houk, V. \& Klee, R. 2003. Morphology, morphological variability and ultrastructure of Cyclotella delicatula Hustedt (Bacillariophyceae) from Hustedt material. Diatom Research 18: 107-121. https://doi.org/10.1080/0269249x.2003.9705576

Schmid, A. M. M. 1994. Aspects of morphogenesis and function of diatom cell-walls with implications for taxononmy. Protoplasma 181: 43-60. https://doi.org/10.1007/bf01666388

Schmidt, R. 1991. Diatomeenanalytische Auswertung laminierter Sedimente für die Beurteilung trophischer Langzeittrends am Beispiel des Mondsees (Oberösterreich). Wasser und Abwasser 35: 109-123.

Šmilauer, P. \& Lepš, P. 2014. Multivariate Analysis of Ecological Data using CANOCO 5. Second Edition. Cambridge University Press.

Solak, C. N., Kulikovskiy, M., Kiss, K. T., Kaleli, M. A., Kociolek, J. P. \& Ács, É., 2018. The distribution of centric diatoms in different river catchments in the Anatolian Peninsula, Turkey. Turkish Journal of Botany 42: 100-122. https://doi.org/10.3906/bot-1703-23

Spaulding, S, \& Edlund, M. 2008. Aulacoseira. In: Diatoms of North America. Retrieved June 04, 2019, from https://diatoms.org/genera/ aulacoseira

Stachura-Suchoples, K. \& Williams, D. M., 2009. Description of Conticribra tricircularis, a new genus and species of Thalassiosirales, with a discussion on its relationship to other continuous cribra species of Thalassiosira Cleve (Bacillariophyta) and its freshwater origin. European Journal of Phycology 44: 477-486. https://doi. org/10.1080/09670260903225431

Teubner, K., 1995. A lightmicroscopical investigation and multivariate statistical analyses of heterovalvar cells of Cyclotella-species (Bacillariophyceae) from lakes of the Berlin-Brandeburg region. Diatom Research 10: 191-205. https://doi.org/10.1080/02692 49x.1995.9705337

Tuji, A., 2015. Distribution and taxonomy of the Aulacoseira distans species complex found in Japanese Harmonic Artificial Reservoirs. Bulletin of the National Museum of Natural Sciences, Tokyo, Series $B:$ 53-60.

Udovič M.G, Cvetkoska A., Žutinić P., Bosak S., Stanković I., Špoljarić I., Mršić G., Borojević K. K., Ćukurin A. \& Plenković-Moraj A. 2017. Defining centric diatoms of most relevant phytoplankton functional groups in deep karst lakes. Hydrobiologia 788: 169-191. https://doi.org/10.1007/s10750-016-2996-z

Wojtal, A. Z. \& Kwandrans, J. 2006. Diatoms of the Wyżyna KrakowskoCzęstochowska upland (S-Poland) Coscinodiscophyceae (Thallassiosirophycidae). Polish Botanical Journal 51: 177-207.

Wolfram, G., Donabau, K. \& Dokulil, M. T. 2013. Leitfaden zur Erhebung der Biologischen Qualitätselemente, Teil B 2 - Phytoplankton. Hrsg. Bundesministerium für Land- und Forstwirtschaft, Umwelt und Wasserwirtschaft, Wien.

Wolfram, G., Buzzi, F., Dokulil, M., Friedl, T. \& Hoehn, E. 2014. Water Framework Directive Intercalibration Technical Report: Alpine lake phytoplankton ecological assessment methods. In: Poikane, S. (ed.), EU Scientific and Technical Research Series. Publications Office of the European Union, Luxembourg.

Wolfram, G., Donabaum, K., Niedermayr, R. \& Krisa, H. 2015. Phytoplankton, Analytik und Bewertung. Bundesministerium für Landund Forstwirtschaft, Umwelt und Wasserwirtschaft, Wien.

Wunsam, S., Schmidt, R. \& Klee, R. 1995. Cyclotella-taxa (Bacillariophyceae) in lakes of the Alpine region and their relationship to environmental variables. Aquatic Sciences 57: 360-386. https://doi. org/10.1007/bf00878399 